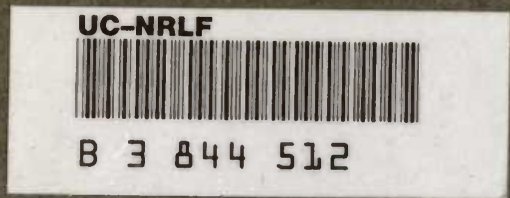




\section{EXCHANGE}

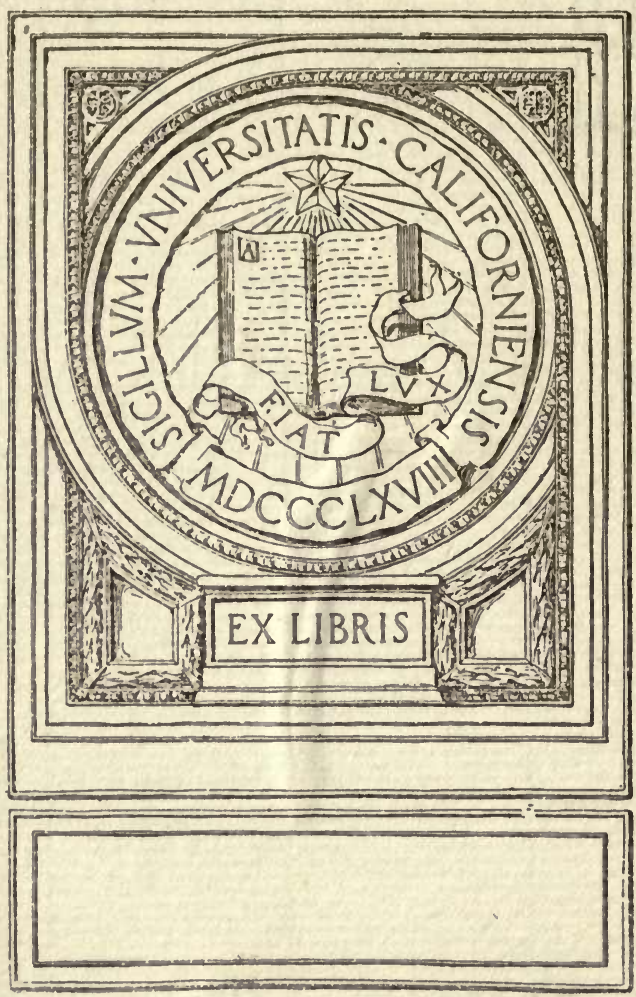




\section{The Insect Fauna of the Genus Crataegus}

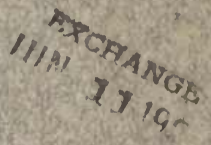

A THESIS

PRESENTED TO THE FACULTY OF THE GRADUATE SCHOOL OF CORNELI, UNIVERSITY FOR THE DEGREE OF DOCTOR OF PHILOSCPHY

\section{BY WALTER HOUSLEY WELLHOUSE}

Reprinted from Cornell University Agricultural Experiment Station Memoir 56 Ithaca, N. Y. June 1922. 



\title{
The Insect Fauna of the Genus Crataegus
}

\author{
A THESIS \\ PRESENTED TO THE FACULTY OF THE GRADUATE SCHOOL OF \\ CORNELL UNIVERSITY FOR THE DEGREE OF \\ DOCTOR OF PHILOSCPHY
}

BY

WALTER HOUSLEY WELLHOUSE

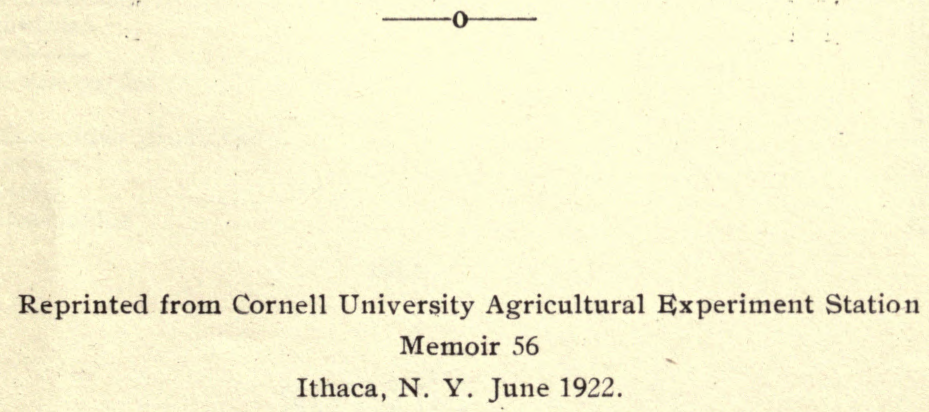

Ithaca, N. Y. June 1922. 
$\therefore$

Exandunese 


\section{CONTENTS}

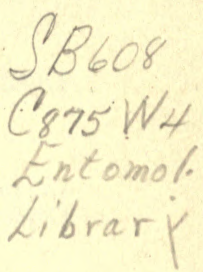

Ecological summary .....................

The relation of Crataegus insects to apple, pear, and quince . . . . . . . . . . . 1050

Biological notes on insects feeding on Crataegus, as observed by the writer from 1917

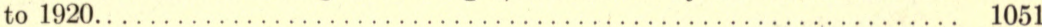

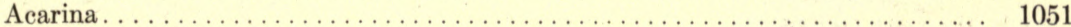

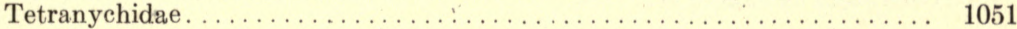

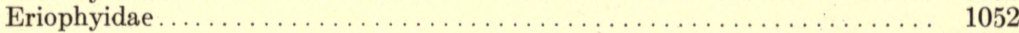

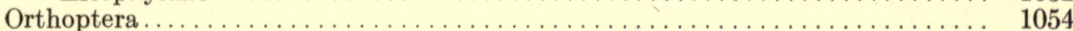

Acridiidae. . . . . . . . . . . . . . . . . . . . . . . . . . . . 1054

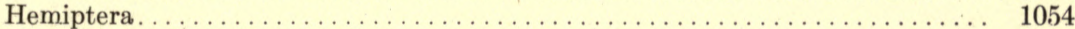

Miridae (Capsidae) . . . . . . . . . . . . . . . . . . . . . . . 1054

Tingitidae . . . . . . . . . . . . . . . . . . . . . . . . . . . 1056

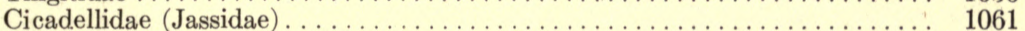

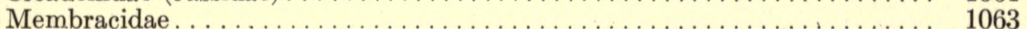

Aphididae. . . . . . . . . . . . . . . . . . . . . . . . . . . . . . . 1063

Coccidae........................................ 1065

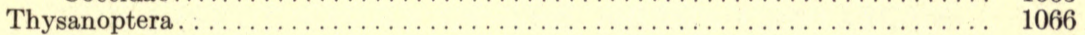

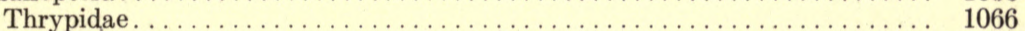

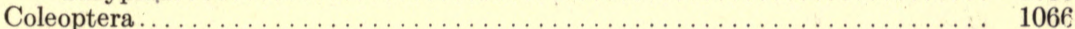

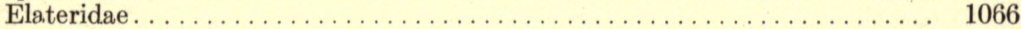

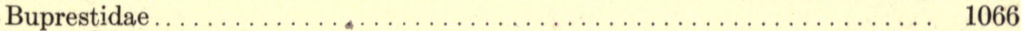

Scarabaeidae ...................................... 1066

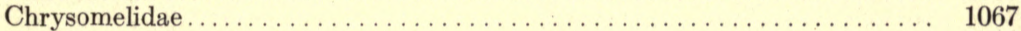

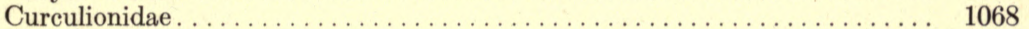

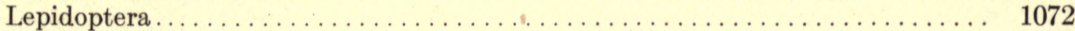

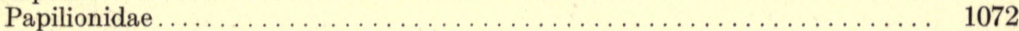

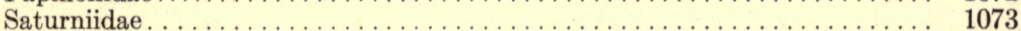

Aretiidae ......................................... 1073

Noctuidae. . . . . . . . . . . . . . . . . . . . . . . . . . . . . . 1073

Notodontidae..................................... 1074

Lymantriidae . . . . . . . . . . . . . . . . . . . . . . . . . . . . . . 1075

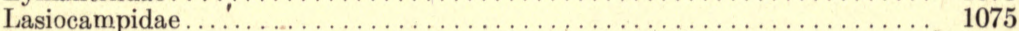

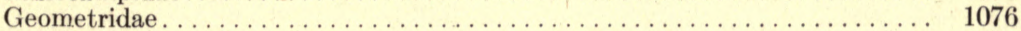

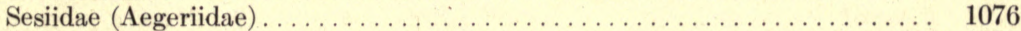

Pyralidae. . . . . . . . . . . . . . . . . . . . . . . . . . . . 1077

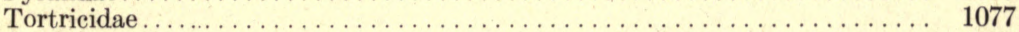

Yponomeutidae ..................................... 1078

Elachistidae ........................................ 1079

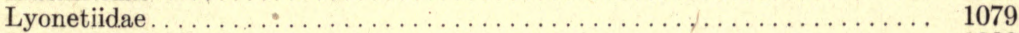

Cosmopterygidae. . . . . . . . . . . . . . . . . . . . . . . . . . . . 1080

Diptera ........................................... 1080

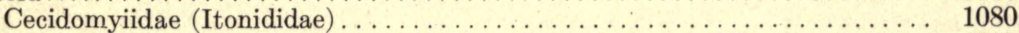

Trypetidae ......................................... 1085

Hymenoptera . . . . . . . . . . . . . . . . . . . . . . . . 1086

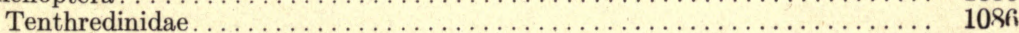


Literature cited

PAGE

Catalog of insects injurious to Crataegus . . . . . . . . . . . . . . . . . . . . . . . . . . . 1090

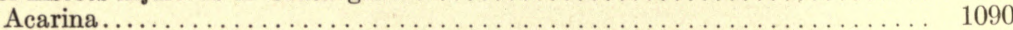

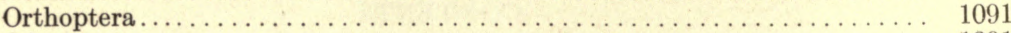

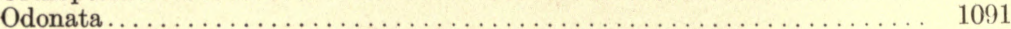

Hemiptera . . . . . . . . . . . . . . . . . . . . . . . . . . . . . . 1091

Thysanoptera ...................................... 1100

Coleoptera ....................................... 1100

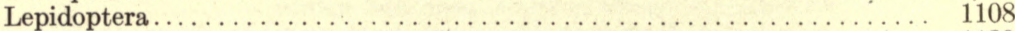

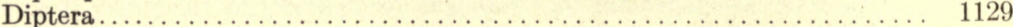

Hymenoptera . . . . . . . . . . . . . . . . . . . . . . . . . . 1131

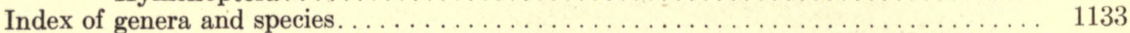


THE INSECT FAUNA OF THE GENUS CRATAEGUS 



\section{THE INSECT FAUNA OF THE GENUS CRATAEGUS}

\section{Walter H. Wellhouse}

This paper is submitted as a result of three years of study of the insects that feed on the plants belonging to the genus Crataegus. The writer's object at the time when the work was undertaken was primarily to learn, by collecting and rearing, what insects occur on the trees of this genus in central New York. As the interest in the work increased, it was decided to widen the field and make the list more complete by including the insects that other workers have found to be eaters of Crataegus.

There are three older lists of insects feeding on Crataegus which have been helpful in the preparation of the present catalog. Kaltenbach $(1872)^{1}$ gives a list of 104 European species, Packard (1890) gives 46 American species, and Felt (1906) gives 28 American species. With the exception of these three lists, the material included in this paper is gathered from widely scattered references and from the writer's observations. Since food-plant indices are very commonly omitted from entomological writings, it is difficult to get a list of all the insects that feed on a plant. Such a list can be obtained only by scanning the pages of a multitude of papers containing biological notes on all orders of insects. Much of that kind of work has been done in the preparation of this catalog, but, since it has not been possible to see all papers that might contain accounts of insects feeding on Crataegus, the writer does not claim that his list is complete.

The catalog contains 382 species, representing 9 orders and 55 families. They are distributed as follows:

Acarina, 10 species:

Eriophyidae. .

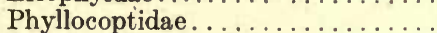

Tetranychidae.............. 2

Orthoptera, 4 species:

Gryllidae.

Acridiidae. . . ....................

Odonata, 1 species:

Agrionidae............... 1

Hemiptera (including Homoptera), 84 species:

Miridae (Capsidae) . . . . . . . . 12

Tingitidae ................ 4

Membracidae............... 4

Cicadellidae (Jassidae) ........... 18

Psyllidae (Chermidøe)........... 7

Aphididae.................. 22

Coccidae................... 17
Thysanoptera, 1 species:

Thrypidae.............. 1

Coleoptera, 74 species:

Elateridae................. 3 .

Buprestidae................ 6

Scarabaeidae................. 4

Cerambycidae............. 5

Chrysomelidae.............. 12

Curculionidae............. 40

Ipidae (Scolytidae)............. 2

Anthribidae................. 1

Dermestidae............... 1

Lepidoptera, 184 species:

Papilionidae............... 2

Nymphalidae................ 2

Pieridae................. 1

Lycaenidae................ 3

Sphingidae.............. 3

${ }^{1}$ Dates in parenthesis refer to Literature Cited, page 1083. 
Lepidoptera (continued):

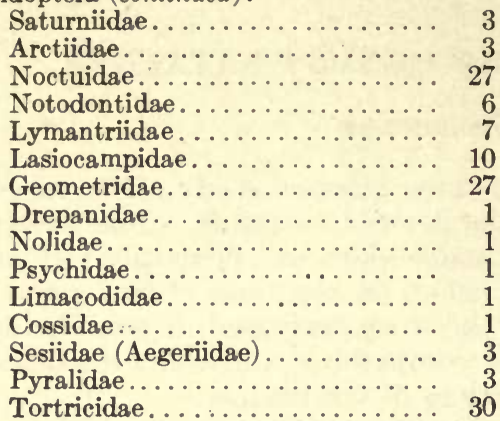

Lepidoptera (continued):

Yponomeutidae............. 7

Gelechiidae................ 6

Elachistidae............... 5

Gracilariidae............... 12

Glyphipterygidae.............. 2

Nepticulidae................. 11

Cosmopterygidae............ 2

Iyonetiidae................. 4

Diptera, 16 species:

Cecidomyiidae (Itonididae) . . . . . 15

Trypetidae................ 1

Hymenoptera, 8 species:

Tenthredinidae. 7

Chalcididae................ 1

The catalog includes insects that have been taken on the Crataegus trees in five continents. The number of species reported from each continent is as follows: North America, 213 species; Europe, 203; Asia, 88; Africa, 11; Australia, 8. All but 45 of the North American species are believed to be distinct from those of the Old World. A single Australian species is distinct from those of other continents. The insects recorded from Asia and Africa are found also in Europe.

It will be noticed that the mites, which have similar habits, are included with the insects in this paper.

Some helpful references to entomological notes concerning each species have been included in the catalog, which is intended as an aid to other workers who are investigating the insects of our deciduous fruit trees and related plants.

Grateful acknowledgment is made to Professors Glenn W. Herrick and James G. Needham, of the Department of Entomology at Cornell University, under whose direction the work was done and whose kindly criticisms and suggestions are appreciated; also to Dr. W. T. M. Forbes, -Dr. Edith M. Patch, Chas. W. Leng, Dr. P. B. Lawson, Professor Z. P. Metcalf, Dr. H. H. Knight, Professor Carl J. Drake, Dr. E. P. Felt, and Henry Dietrich, who have kindly aided in the determination of species; to Dr. K. M. Wiegand, who has kindly aided in the determination of species of Crataegus; and to Miss Lela G. Gross for able editorial assistance.

\section{THE GENUS CRATAEGUS}

Crataegus is the name of a group of trees and shrubs commonly known by their sharp thorns, white flowers (pink or red in a few cultivated varieties) in May, and red or yellowish fruit like minature apples in autumn. It is an ancient Greek name derived from kratos (strength), and was applied to the plants of this genus because of the hardness and durability of the wood. 
Among the popular names by which the genus is known most commonly are the following: hawthorn, thorn apple, red haw, white thorn, and thorn, in America; hawthorn and may, in England; aubepine, in France (snellier, by French Canadians); Weissdorn, in Germany; spinalba, in Italy. As the name hawthorn seems to be the one most commonly used by Englishspeaking peoples, the writer has used it in this paper to represent all species of Crataegus.

The genus is placed by many botanists in the family Rosaceae. Other botanists have divided the Rosaceae group and formed an apple family, Malaceae, in which Crataegus is included along with Malus, Pyrus, Cydonia, Mespilus, Sorbus, Amelanchier, Aronia, and Eriobotrya.

The determination of species of Crataegus is as great a taxonomic problem to botanists as the determination of the parasitic Hymenoptera is to entomologists. During the first ten years of this century about one thousand species of Crataegus were described in North America. Many of them are now regarded as hybrids and varieties, and a still further reduction of species is in progress. This taxonomic uncertainty makes it impossible in many cases to recognize specific hosts for the insects that feed on the hawthorns.

Crataegus is distributed over most of the temperate parts of the Northern Hemisphere. The genus is not indigenous in the Southern Hemisphere except in Amsrica, where it follows the unbroken mountain chain through the Tropics and grows in the Andes Mountains. It is found as far north as Newfoundland, Norway, and Sweden, and extends southward to the Mediterranean borders of Africa and Asia Minor. The European species have been introduced into Australia and other Europzan colonies in the Southern Hemisphere for cultivation.

Most species of hawthorns seem to thrive in any well-drained soil which is not acid and where rainfall is sufficient for the growth of forest trees, while a few species thrive in acid soils also. They are usually long-lived trees, and individuals one hundred years old are not uncommon.

Distribution is effected largely by means of birds and mammals, which eat the ripe fruits and carry the seeds in their digestive tracts to other communities. Within the same community, thickets are commonly formed from the new stems which grow from the roots of a single tree. Wherever the roots become exposed to light, as by washing on hillsides, a new stem may grow and a tree be formed from it.

\section{ECOLOGICAL SUMMARY}

The ecological relations of the hawthorns to their insect fauna may be summarized in a general way very briefly. The two basic needs of an insect which it is possible for a host plant to supply are food and shelter. The hawthorns furnish both food and shelter. 
They furnish food for nearly all of the insects studied. A few exceptions, such as the snowy tree cricket (Oecanthus niveus) and the damsel fly Lestes viridis, procure their food elsewhere and use the hawthorn branches merely to shelter their eggs from the weather and their enemies. Every part of the tree furnishes food for some species of insect, as may be seen from the following outline:

Trunk and branches

40 species

A. External feeders (scales, aphids, and cthers), 19

B. Internal feeders (borers), 21

Roots (aphids)...

Thorns (weevils).

Leaves

292

A. External feeders (miscellaneous), 235

B. Miners (tineids, weevils, sawflies), 37

C. Gall makers (aphids, mites, cecidomyiids), 20

Flowers (thrips, maggots, caterpillars, beetles, and others)

Fruit (caterpillars, bugs, maggots, grubs)

The other basic need of insects which a host plant may supply is shelter. Most of the insects included in this paper are sheltered to some extent by the hawthorn, although the completeness of the shelter varies with the habits of each species of insect. Some are protected only by their position on the surface of the tree. Others are partially sheltered in rolled leaves, bark crevices, and the like. Still others are securely housed within the plant tissues. The degree of shelter secured by those species living externally on the surface of the plant varies so greatly and so gradually that no distinct lines of division can be drawn in so general a statement as this. The more distinct groups of internal feeders (borers, leaf miners, and gall makers) are indicated above and are distinguished from the external feeders, which receive less complete shelter.

The fact that so many species of insects feed at the expense of the hawthorns suggests the idea that these trees are in danger of extinction. Such is not the case, however, for the hawthorns when not weakened by drought or flood are very hardy, long-lived trees. Some indications as to why they so successfully withstand the feeding of the insects may be seen from a study of the following data, which are based on statistics given in the last sections of this paper:

Approximate Feeding Period of Hawthorn Insects

Species

Species

March..................... 11

August.................. 117

April.................... 54

May........................ 190

June . . . . . . . . . . . . . . . 232

190 October..................... 80

July ........................ 131

November.

23

Time of feeding unknown

58

Food Plants of Hawthorn Insects

Food plants restricted to Crataegus. 
It will be noticed that there is a direct correspondence between the time of feeding of the insects and the time of growth of the trees. The greatest number of species feed during May and June, when the trees make their greatest growth. The number decreases slightly during July and August, at the time when droughts frequently check tree growth; and then it increases slightly in September, at the time when fall rains often cause a new growth. This relationship between the period of growth and the time of feeding seems to be one of Nature's adjustments for maint ining balance.

The fact that a large majority of the insects feed on other host plants also, lessens the danger of destruction of the hawthorns and is another of Nature's provisions for maintaining balance. There are, of course, many other factors that tend to lessen the insect injury to the trees, such as the interrelations of the insects with their parasites and preyers, but so little is known about them that the writer makes no attempt to discuss them.

A host of bees, flies, and beetles visit the blossoms in quest of pollen and nectar. The winter buds in some species of hawthorn become coated with a sticky exudation, which attracts insects emerging in late winter, such as the stone flies and the chironomids. These transient members of the Crataegus fauna have been omitted from consideration in this paper. A list of insects that visit the blossoms is given by Knuth (1908).

In the preparation of the catalog of hawthorn insects it became noticeable that some of the species which have more than one host plant have chosen only closely related hosts, such as the apple, the pear, or the medlar, while many others have chosen their hosts from plants that grow in the same communities regardless of close botanical relationship. A study of these combinations of hosts and the habitats in which they grow has led the writer to believe that the hawthorns are members of at least five different plant communities, which may be described as follows:

1. Open woods. In woodlands where the growth habit of the taller trees permits sunlight to reach the ground so that an undergrowth may develop, such as that in a forest of oak, hickory, and elm, Crataeg as is commonly found along with Corylus, Rhamnus, Carpinus, Prunus spinosa, and the like.

2. Deforested areas. Where a shrubby growth has sprung up after the destruction of a forest, numerous thorny forms such as Crataegus, Rubus, Berberis, and Prunus spinosa are frequently found.

3. Grazing lands. Hillsides or valleys where the soil is uncultivated and cattle are pastured are frequently dotted with Crataegus, Rosa, and crab apple, which because of their thorns can continue to thrive and outgrow the danger of being eaten by the cattle.

4. Stream banks. Just back of the willows and alders on moist alluvial soil beside streams, Crataegus grows to its greatest size and is associated with birch, willow, alder, and poplar.

5. Fence rows. Where shrubs are allowed to grow up along the fences, Prunus virginiana, Crataegus, wild plum, and wild cherry are frequently found closely associated.

In each of these five communities insects will be found which feed on the various plants of the community. For example, Psylla mali Schmid. 
feeds on Crataegus, Malus, Sorbus, Quercus, Ulmus, and Corylus, which may all be found in the open-woods community, as may the host plants of the flat-headed apple-tree borer, Chrysobothris femorata Fabr. On the other hand, the leaf beetle, Cryptocephalus bipunctatus Linn., feeds near the streams on such plants as Salix, Betula, Crataegus, and Corylus, and Agrilus vittaticollis Rand. is found along the fence rows on Crataegus, Prunus virginiana, and Amelanchier. No very distinct lines can be drawn between the members of these communities, since many of the plants and insects belong to more than one community.

\section{THE RELATION OF CRATAEGUS INSECTS TO APPLE, PEAR, AND QUINCE}

A more complete knowledge of the insects that feed on Crataegus is of considerable importance as an aid in the control of insect pests of the cultivated commercial fruits. It has for many years, since the days of Walsh and Riley, been recognized by entomologists as the original native host plant of a number of important insect pests which now attack the apple, the pear, and the quince in the northeastern section of the United States. In all probability new pests must be expected to attack the cultivated fruits in the future as the population of the country increases, since as a consequence less uncultivated land will remain where the insects may feed undisturbed on their natural hosts.

The main commercial fruits of the United States, such as the apple, the pear, the quince, and the cherry, are natives of the Old World and have been imported by man into America. With them were imported a number of foreign insects, such as the codling moth, the bud moth, and the sinuate pear borer, which continued to feed on them in this country. Many of the pests now destructive to these fruits, however, are native to North America and are not found in the Old World. Before the extensive planting of the imported fruits these insects must have fed on native plants. Among the most numerous of the native plants which are similar to the apple, the pear, and the quince are those of the genus Crataegus, and the members of this genus are widely distributed throughout many of our commercial fruit districts.

A young orchard which is set in the midst of hawthorns may be ruined in a few years by the insects that migrate to it from the surrounding trees. Well-established orchards may suffer from the attacks of new pests whenever there is a failure of the crop of wild haws or a clearing of the land occupied by hawthorns so that their natural guests must seek other hosts.

It is commonly known among entomologists that the apple maggot, Rhagoletis pomonella, was originally a hawthorn insect and that after the apple had been cultivated in North America for many years this insect selected the larger, juicier fruit of the apple for its home. It is still found in the haws but is now known as an apple pest. 
The apple redbug, Heterocordylus malinus, is another hawthorn insect which has adopted the apple. It was formerly believed that the false apple redbug, Lygidea mendax, was also originally a hawthorn insect, but the observations of Cushman (1916), as well as those of the writer, indicate that $L$. mendax is a wild-crab insect and does not feed extensively on hawthorns.

The quince curculio, Conotrachelus crataegi, is a very common feeder in haws which has occasionally injured quinces seriously and has thus gained its common name. Likewise the lesser apple worm, Laspeyresia prunivora, has gained its common name because of occasional migrations from hawthorn to apple.

Baker (1915:10) considers the woolly apple aphis, Eriosoma lanigera, to have been originally an elm-Crataegus feeder which has adopted the apple and traveled around the world with it. The woolly aphis is undoubtedly common on hawthorns.

Numerous other native American insects that feed on apple, pear, or quince are included in the catalog of hawthorn feeders beginning on page 1090 .

The possibility that foreign hawthorn insects may be imported and become pests in North America should also be considered. When introduced into a new environment away from their natural checks, these may become more important here. Recent examples of this are three small moths imported from Europe - the apple and thorn leaf skeletonizer, Simaethis pariana; the hawthorn ermine moth, Yponomeuta padellus; and the lesser bud moth, Recurvaria nanella. These have attracted the attention of economic entomologists in North America as apple and cherry pests, while in Europe they feed commonly on hawthorns.

Since the catalog of hawthorn insects included in this memoir lists their food plants and the continents where each species occurs, further examples of foreign hawthorn insects that are now in North America may be found there.

BIOLOGICAL NOTES ON INSECTS FEEDING ON CRATAEGUS, AS OBSERVED BY THE WRITER FROM 1917 TO $1920^{2}$

ACARINA

\section{Tetranychidae}

telarius Linn., Tetranychus (Red spider)

The leaves of all species of Crataegus observed showed attack by Tetranychus telarius. The European hawthorns, however, seem to be more often severely injured by these mites than the native species. The

2 The insects are grouped according to order and family, and arranged alphabetically by species within the family. 
injury is severest in warm, dry periods. The leaves at first become grayish, due to the presence of a fine white web and the cast skins of the mites attached to them. Later they turn brown and their margins curl toward the surface on which the mites have fed. The adults hibernate among the fallen leaves and a few were found in bark crevices on the trunk in April. The tiny, round, white eggs are laid on the leaves. The mites breed continually on the leaves from June to October.

\section{Eriophyidae}

Eriophyes sp. No. 1 (Hawthorn serpentine gall of Jarvis)

The species of Eriophyes here described produces long, green or red, serpentine galls confined to the space between two of the larger veins and extending from the midrib toward the margin of the leaf (fig. 102). The

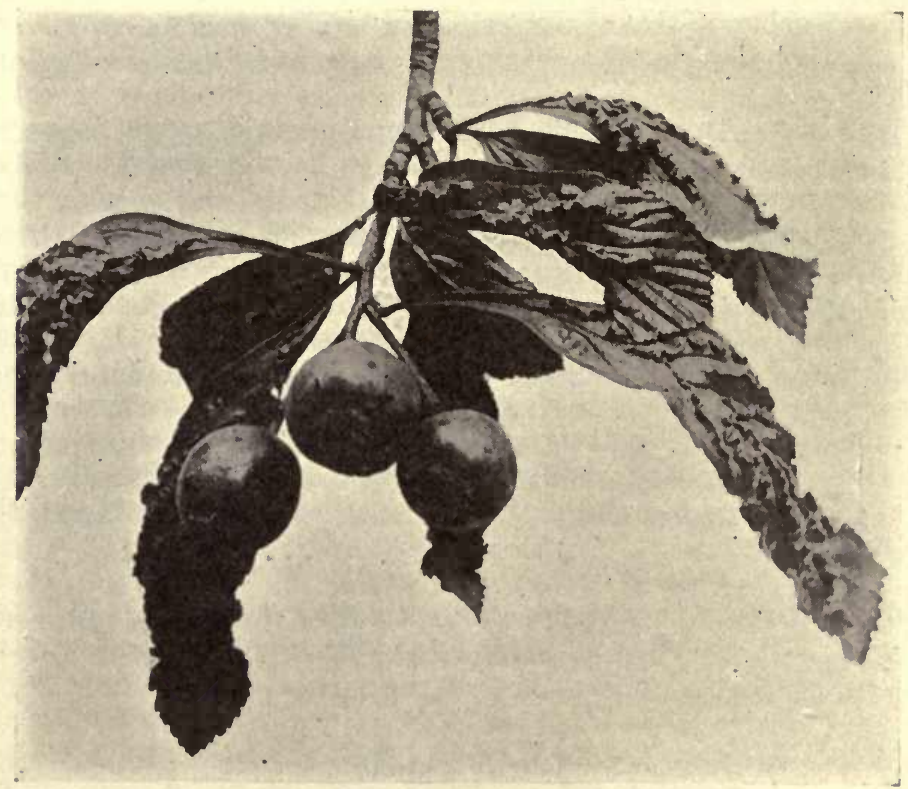

Fig. 102. Leaves of craetaeguz punctata showing serpentine galls PRODU CED BY ERIOPHYES SP. NO. 1

gall consists of a wavy projection on the upper side of the leaf and a wavy incision on the lower side. In cross section the leaf appears convoluted, with the galls projecting upward as loops or pockets in which the mites 
live (fig. 103). The leaf does not become thickened in these galls. The galls become extremely abundant on some trees, so that almost every leaf is deformed. The mites seem to prefer the shady branches of trees, rather than those in bright sunlight. They become most abundant during August, when the galls are swarming with the microscopic white mites. The galls were found most abundantly on Crataegus punctata, but they were found also on $C$. pruinosa and other native hawthorns.

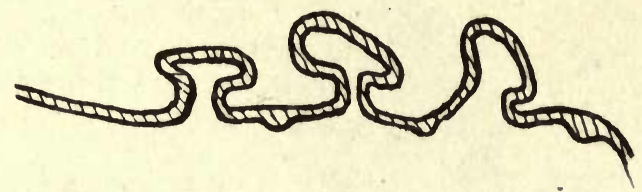

Fig. 103. Cross Section of a CRATAegus leaf, THROUGH THREE SERPENTINE GALLS

Eriophyes sp. No. 2 (Hawthorn

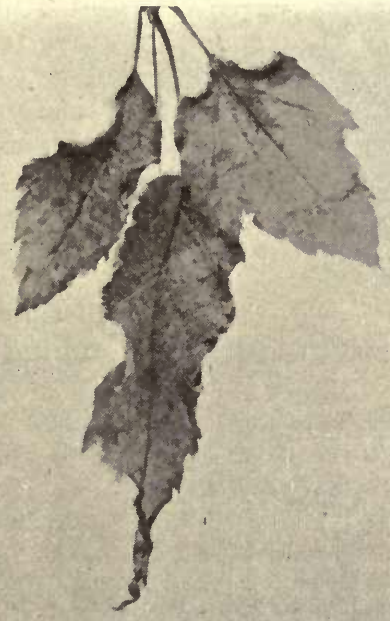
marginal gall)

Galls very similar to those of Eriophyes goniothorax Nal., which are found on hawthorns in Europe, are produced by Eriophyes sp. No. 2. The margin of the leaf is curled tightly downward for a distance of two centimeters or more (figs. 104 and 105), and the curled margin is paler green than the rest of the leaf. The mites live within the curl. This gall is not very common about Ithaca, but was found in a few cases on Crataegus coccinea.

Eriophyes sp. No. 3 (Thorn leaf pouch gall)

Many small, pale green pouches, standing on the upper side of the leaf and opening beneath the leaf by a small slit,

Fig. 104. HAWTHORN MARgiNal GALLS are caused by microscopic

white mites which live within the pouches. The galls vary in size and shape, but are generally about two millimeters high and are rounded on top (figs. 106 and 107). They may be found at any place on the leaf except on the larger veins. They are fairly common on Crataegus punctata but are not so abundant as the serpentine galls.

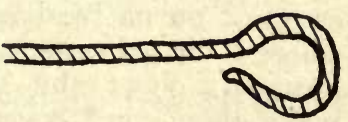

Fig. 105. CROSS SECTION THROUGH CURLED EDGE OF LEAF 


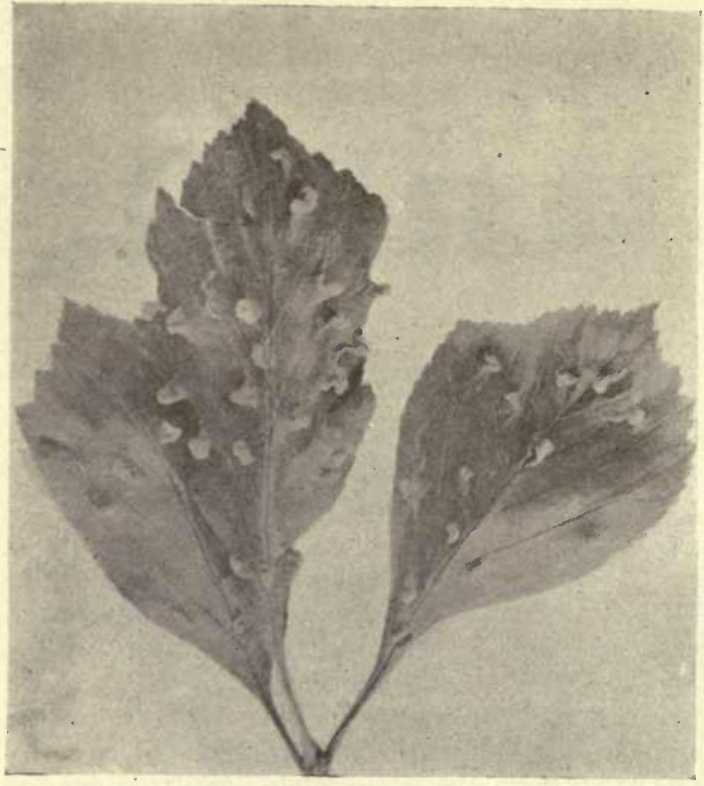

Fig. 106. THORN LEAF POUCH GALLS
ORTHOPTERA

Acridiidae

atlanis Riley, Melanoplus bivittatus Say, $M$.

femur-rubrum De Geer, $M$.

The common grasshoppers Melanoplus atlanis, $M$. bivittatus, and $M$. femur-rubrum sometimes leave their herbaceous host plants to feed on the foliage of the lower branches of hawthorn trees. The older nymphs and adults have been observed feeding in August and September. They feed irregularly on the leaves, sometimes eating the entire leaf and sometimes eating only the apex or one side of it.

\section{HEMIPTERA \\ Miridae (Capsidae)}

communis Knight, Lygus

One adult of Lygus communis was taken on June 21 and four were taken on August 2, puncturing the leaves of Crataegus punctata.

dislocatus Say, Horcias

A few adults of Horcias dislocatus were found feeding on leaves of $\mathrm{Cra}$ taegus punctata in June. They are black, rather stout, and 6 millimeters long.

malinus Reuter, Heterocordylus

(Dark apple redbug)

Nymphs and adults of Heterocordylus malinus are very common on native hawthorns, where their red color and rapid running over the branches make them very conspicuous. The young nymphs begin to appear about April 15, when

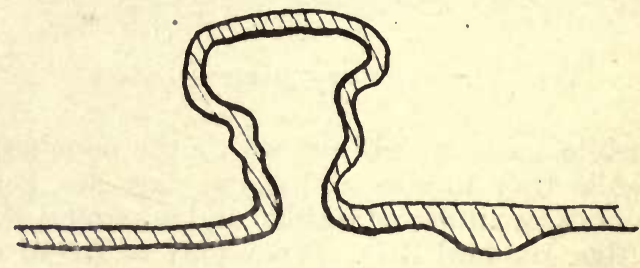

Fig. 107. CROSS SECTION THROUGH A THORN LEAF POUCH GALL 
the blossom clusters have just begun to separate and before the blossoms show pink. They puncture the leaves and the tender twigs but do not cause any noticeable injury. After the fruit sets they feed on the fruit also and cause very slight dimples where they puncture it. They become adult in late May and early June, and begin ovipositing in the twigs about June 15. The egg is deposited in a small slit made with the beak at the base of a young twig. Adults were found on the trees until late July. mendax Reuter, Lygidea (Bright apple redbug)

A few nymphs of Lygidea mendax were found feeding on the leaves and fruit of Crataegus in late April and in May. They are not so common as Heterocordylus malinus. In the warm laboratory the eggs hatched on March 27 on Crataegus punctata twigs, but no nymphs were found in the field until the blossoms were opening on April 25. Adults were found from June 2 to August 14. One adult in a breeding cage oviposited on June 19 in a twig of Crataegus crus-galli. She chose a year-old twig, drilled a hole through the bark at the base of the twig, and then, turning about, thrust an egg into the cavity.

ornatus VanD., Orthotylus

A few adults of Orthotylus ornatus were found feeding on the leaves of Crataegus pruinosa in June. They are brownish, spotted, slender, and 5.5 millimeters long.

ostryae Knight, Lygus

A few adults of Lygus ostryae were taken puncturing the leaves of Crataegus punctata in late June. They are pale yellowish brown, and are otherwise similar in appearance to the tarnished plant bug.

pellucida Uhl., Diaphnidia

The pale green nymphs of Diaphnidia pellucida are rather numerous on the foliage of Crataegus punctata during late May and early June. They run rapidly over the branches when disturbed, and feed on the leaves and tender twigs. Adults appeared from June 10 to June 15 in rearing cages in the laboratory, and others were found in the field on Jun 18. They are delicate, slender, pale green, and about 4 millimeters long.

pratensis Linn., Lygus

Adults of Lygus pratensis which have lived through the winter are sometimes found puncturing the buds of Crataegus in April, as soon as the buds show green, and a few were found puncturing the young fruit in late May.

univittatus Knight, Lygus

Adults of Lygus univittatus are rather common during late May and June, puncturing the leaves and fruit of native hawthorns. They resemble. $L$. communis very closely, but are generally paler. 


\section{Tingitidae}

bellula Gibson, Corythucha (Plates LXXII and LXXIII)

Although the original description of Corythucha bellula was published but recently (Gibson, 1918), the species seems to be fairly common where its host plants occur, and it has probably been confused with $C$. cydoniae by earlier observers who must have seen it on the hawthorns. It has been found by Drake in Ohio and by Criddle in Manitoba.

The host plants include those species of Crataegus that have hairy leaf veins, and also Alnus incana and Ribes oxyacanthoides. The writer has found the insect breeding in abundance on Crataegus neofluvialis and to some extent on $C$. albicans and $C$. punctata. The hawthorns with smooth leaves, such as $C$. pruinosa, $C$. crus-galli, and $C$. oxyacantha, even when their branches were intermingled with those of trees that were badly infested, revealed no nymphs nor eggs.

In a large thicket of $C$. neofluvialis trees near the Cornell University campus, the leaves were so discolored by the end of July that they attracted attention several hundred yards away. By the middle of August the leaves were falling, and the branches were bare by September 1 . No fruit matured on these trees. A few scattered trees of this species in other directions from the city were also badly infested. Individual trees of $C$. albicans and $C$. punctata showed an occasional branch badly infested and with leaves discolored. The injury is caused by the nymphs and the adults puncturing the under surface of the leaf and sucking the sap, producing at first a mottled effect due to the pale areas around the feeding punctures, while later the leaf turns brown and falls to the ground. Ornamental plantings of Crataegus in parks and gardens are rendered unsightly and weakened by this injury.

There are two generations annually at Ithaca. The first brood hatches in July from eggs laid in late May and in June, and the nymphs become mature in from twenty to twenty-five days. The second-brood eggs are laid in late July and in August, and the adults appear in late August and in September.

The adults of the second brood hibernate among the fallen leaves and in erevices of the bark. Many of them remain on the leaves on which they were feeding before the leaves fell. They appeared the last of May, and during early June were feeding on the new Crataegus leaves. As a rule only one pair of adults was found on a leaf, and they remained feeding and ovipositing on that same leaf for several days. 'After emergence from the nymphal skin in September, the adults of the second brood continue feeding on the leaves until they fall, in late September or in October.

The egg is subelliptical, with the basal end rounded and the apical end bent slightly to one side and capped with a rather broad cylindrical collar 

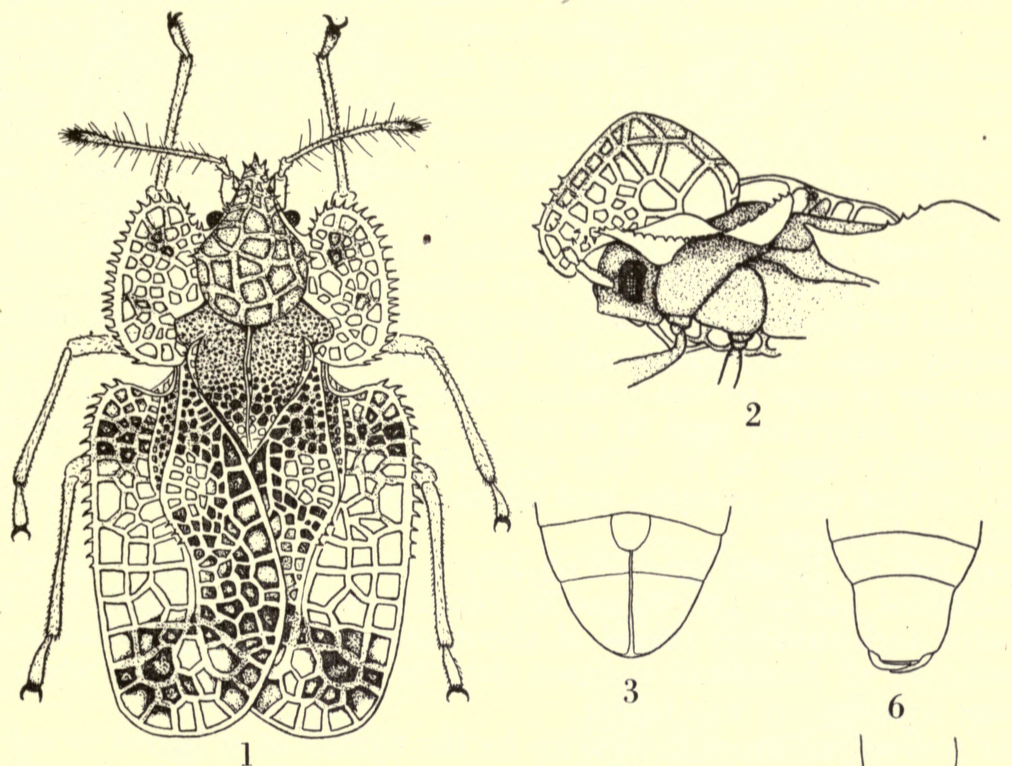

2

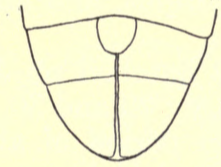

3

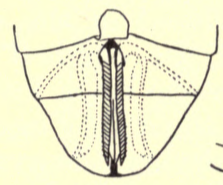

4

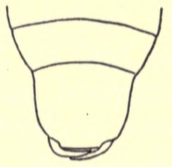

6

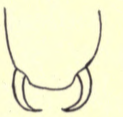

7

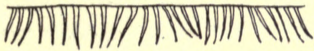

8

CORY'THUCHA BELLULA

1, Adult. 2, Lateral view of hood and carina. 3, Tip of abdomen of female, with ovipositor at rest. 4, Same with ovipositor exserted; chitinized parts within body shown by dotted lines. 5, Ovipositor. 6, Tip of abdomen of male, with claspers at rest. 7, Same with claspers exserted. 8, Eggs in position among hairs in axil of leaf veins 
surmounted by a low cone with irregular ridges extending from base to apex. From the apex of this cone there arises in some cases a short, blunt prolongation, but often this is absent. The egg is without waxy covering over the chorion, which is smooth, unsculptured, and of a shining darkbrown color but somewhat lighter toward the base. The cap, or cone, is often whitish. The egg, exclusive of the apical prolongation of the cap, is 0.52 millimeter long, and 0.21 millimeter broad at its greatest width.

The eggs are laid on the under surface of the leaf, in the axils formed by the midrib and its lateral branches. Although the female has a welldeveloped, sawlike, four-valved ovipositor, the eggs are not inserted into the leaf tissue. They are placed among the hairs on the veins and are in some cases glued together with an adhesive material. They are generally laid in small groups, some groups containing as many as eighteen or twenty eggs; but occasionally they are laid singly. In counting the number of eggs on one hundred infested leaves the writer found an average of forty-nine eggs to a leaf. Occasionally a leaf had seventyfive or eighty eggs on it. The egg-laying period extends over several weeks, so that eggs, nymphs, and adults may be found at the same time in July and August.

Eggs laid on June 2 hatched on July 9 and 10, while the eggs of the second brood, laid on July 29 and 30, hatched on August 15 and 16 . This indicates an incubation period of about thirty-seven days in the cooler temperature of June, and eighteen days in July and August when the average temperature was higher.

The conical egg cap is pushed up by the nymph as it begins to emerge from the egg still inclosed in the embryonic membranous sac. When about halfway out of the eggshell the nymph splits the membranous sac and slips it off over the head, leaving it with the egg cap on the outer end hanging out from the empty eggshell.

After emerging and drying, the nymphs begin to feed at once in colonies near the eggshells. They molt five times, feeding from three to six days between molts, the earlier stages requiring three or four days while the later ones require five or six days. In molting, the cuticula breaks along the median dorsal line from the front of the head to about the second abdominal segment. The insect on emerging is limp, and is almost colorless except for the eye facets which are bright red. The body color soon darkens and the eyes a few hours later become black. During the fifth stage the nymph wanders about more freely over the leaf and in some cases goes to adjoining leaves. Descriptions of the nymphal stages follow.

First stage. - Length $0.5 \mathrm{~mm}$., greatest width $0.15 \mathrm{~mm}$. General shape an elongate ellipse, somewhat broader cephalad than caudad and more elongate than in the later stages. At first almost colorless but soon becoming dark brown. Beak 4-segmented and extending back to sixth abdominal segment. Antenna 3-segmented, the basal two segments being shorter than the third segment; basal segment without spines or hairs, second segment with 
MeMoIR 56
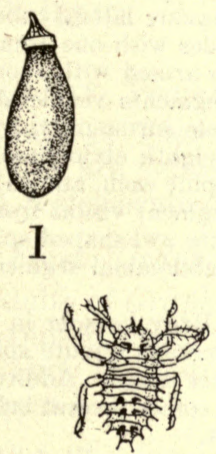

3
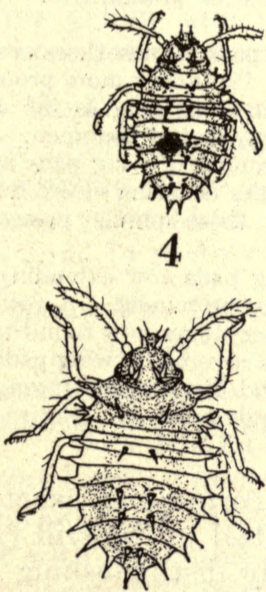

5
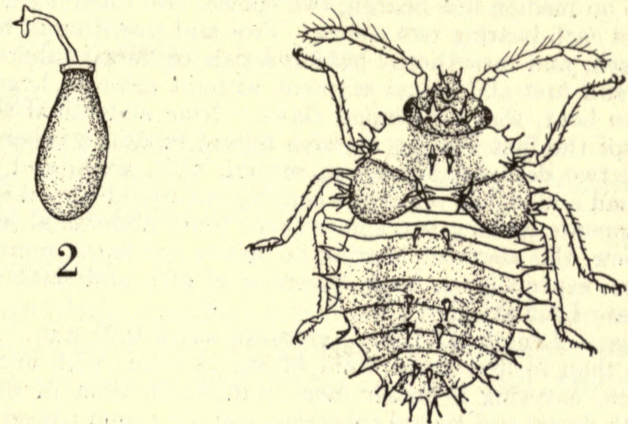

6

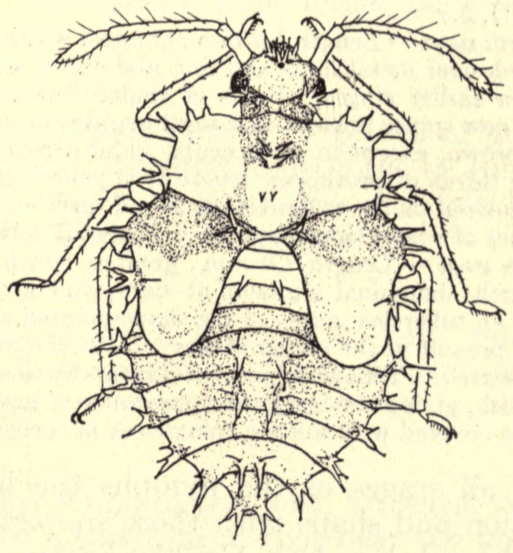

7

YOUNG STAGES OF CORYTHUCHA BELLULA

1. Egg. 2, Egg after hatching. 3, First-stage nymph. 4, Second-stage nymph. 5, Thirdstage nymph. 6, Fourth-stage nymph. 7, Fifth-stage nymph 
a few short hairs, third segment with numerous long spines and hairs, some with rounded tip and conical base, others with pointed tip. Head with five prominent dorsal tubercles, two slightly separated just above base of beak, each bearing a round-tipped spine; one tubercle back of these on median line bearing two spines; two tubercles near posterior margin, widely separated and each bearing two spines. Pro- and mesothorax having lateral tubercles with a spine on each, and mesothorax having a pair of dorsal tubercles with one spine on each. Metathorax and first abdominal segment without spines. Legs armed with short, pointed hairs and two bent, sharp, terminal claws. Nine abdominal segments visible above, each of these except the first bearing on each lateral margin a tubercle surmounted by a roundtipped spine; two dorsal tubercles on second, fifth, sixth, and eighth abdominal segments, those on second and eighth segments bearing one round-tipped spine each, and those on fifth and sixth segments bearing two spines each; tenth abdominal segment visible from a lateral or ventral view, this segment bearing no spines nor hairs; minute awl-shaped spinules over dorsal surface, especially on large tubercles of fifth and sixth abdominal segments and on thorax. (Plate LXXIII, 3.)

Second stage.- Length $0.68 \mathrm{~mm}$., greatest width $0.27 \mathrm{~mm}$. Body broader in proportion to its length than in first stage; dark brown in color, with numerous minute spinules over dorsal surface, covering it much more completely than in first stage. Additional small spines on both dorsal and lateral tubercles, and the round-tipped spines present before having a slightly longer conical base in this stage. (Plate LXXIII, 4.)

Third stage. - Length $0.82 \mathrm{~mm}$., greatest width $0.44 \mathrm{~mm}$. Antenna with four segments. Round-tipped spines arising from a base longer than the spines, and a few additional small spines on tubercles. Pro- and mesothorax beginning to increase in prominence. (Plate LXXIII, 5.)

Fourth stage.- Length $1.2 \mathrm{~mm}$, greatest width $0.7 \mathrm{~mm}$. Wing pads of mesothorax extending back over metathorax and first abdominal segment at sides. Prothorax more prominent than in earlier stages. Bases of round-tipped spines several times as long as the spines. A few new spines present on lateral margins of pro- and mesothorax and of abdomen. Color dark brown, except in an irregular band across abdomen just caudad of wing pads and on lateral thirds of prothorax, where it is yellowish. Minute spinules covering entire dorsum, light-colored on the yellowish parts and dark on the brown parts; these spinules present also on bases of round-tipped spines. (Plate LXXIII, 6.)

Fifth stage.- Length $1.6 \mathrm{~mm}$., greatest width $0.96 \mathrm{~mm}$. Wing pads now extending back to fourth abdominal segment at sides, and prothorax still more prominent. A few more spines on tubercles; many of the sharp-pointed spines of the earlier stages now round-tipped; spines present in the earlier stages on lateral margins of segments covered by wing pads have disappeared. Yellowish parts of prothorax increased in size, and distal part of wing pads yellowish, giving the body the appearance of having two light bands across it. Entire dorsal surface covered with minute spinules as in earlier stages. (Plate LXXIII, 7.)

In all stages of the nymphs the larger spines correspond exactly in position and shape with those so excellently described by Morrill (1903) for the oak lace bug, Corythucha arcuata. The only distinguishing characters between the nymphs of the two species which the writer has been able to observe are the size and the prevalence of minute awl-shaped spinules on the dorsal surface. Nymphs of $C$. bellula are smaller, and possess more spinules, than those of $C$. arcuata. The larger spines of both species which are mounted on elongate bases seem to have an eversible sac on the tip which gives them a trumpet shape when it is drawn in and a round tip when it is extended.

The natural enemies of these spiny creatures seem to be few. the immature stages of several spiders were seen to prey upon them. 
The webs of these spiders sometimes cover the infested leaves of a tree and entangle whole colonies of the lace bugs. The adults that survive the winter are comparatively few, so that the first brood of $C$. bellula does little injury.

\section{Cicadellidae (Jassidae)}

clitellarius Say, Thamnotettix

The adults of Thamnotettix clitellarius are of medium size, 5 millimeters long. They are yellow, with black wings which have a prominent yellow spot. A few specimens were found on June 11.

coccinea Först., Graphocephala

The adults of Graphocephala coccinea are 8 millimeters long, are slender, with a pointed head, and have the wings striped with alternate red and green. They are found on native hawthorns in July and August, but are not common.

curtisii Fb., Euscelis

The adults of Euscelis curtisii are small, 4 millimeters long, with many narrow yellow and black stripes. Specimens were found on June 23, but were not common.

fitchi VanD., Idiocerus (Black apple leaf hopper)

The adult of Idiocerus fitchi is 6 millimaters long, is brown or grayish with oblique white marks, and is found on native hawthorns in July and August. The black nymphs were reared on Crataegus punctata leaves from June 14 to July 2 . The species winters in the egg stage.

lachrymalis Fb., Idiocerus

The adults of Idiocerus lachrymalis are 8 millimeters long, and are brownish or grayish mottled, with dark venation. They occur on native hawthorns in June and July. They are not common.

lineatus Linn., Philaenus

The adults of Philaenus lineatus are 6 millimeters long, brownish yellow, stout with a pointed head, and with a small black spot near the apex on the inner margin of the wing. They are found on native hawthorns from July 1 to July 15 , but are not common.

mali LeB., Empoasca (Apple leaf hopper)

The adults of Empoasca mali are $3 \frac{1}{2}$ millimeters long, slender, pale green. They are found rarely on Crataegus in late June.

obliqua Say, Erythroneura

The adults of Erythroneura obliqua are $2 \frac{1}{2}$ millimeters long, with the wings striped red and white. They are very abundant on the leaves of native 
hawthorns. They hibernate among the fallen leaves under the trees, and hundreds of them were present under Crataegus punctata trees in March, 1919. During warm days in winter they hop about over the leaves. Some individuals have pale pink stripes, and others reddish brown. Adults are found feeding on the trees in June and October.

pallidus Fb., Idiocerus

A single adult of Idiocerus pallidus was taken on June 23, on Crataegus punctata. It was 6 millimeters long, and was similar in size and shape to $I$. fitchi but was almost white.

provancheri VanD., Idiocerus

The adults of Idiocerus provancheri are $5 \frac{1}{2}$ millimeters long, and are brown or blackish with an elongate yellow spot on the base of the inner margin of the wing. They are common on the leaves of native hawthorns during June and July. Nymphs in the rearing cages hatched from eggs in Crataegus punctata twigs just as the buds were expanding in April. They became adult in three weeks.

querci Fitch, Empoa

The small, whitish leaf hoppers known as Empoa querci are very abundant on both native and imported hawthorns. The nymphs may be found on the under side of the leaves in late June and July, and again in September. The adults likewise occur on the under side of the foliage in June, August, and late September or early October. They hibernate among the fallen leaves and become active on warm winter days. They are 3 millimeters long, and are pale yellowish white in color.

seminudus Say, Eutettix

The adults of Eutettix seminudus are $4 \frac{1}{2}$ millimeters long, rather stout, and white with a light brown band across the middle of the wings. They are rather common on Crataegus punctata and $C$. tomentosa foliage from mid-July to September.

suturalis $\mathrm{Fb}$., Idiocerus

The adults of Idiocerus suturalis are $5 \frac{1}{2}$ millimeters long, and are pallid except for the black inner margin of the wings. They are found on native Crataegus in June and July, but are rare.

vanduzei Gill., Eupteryx

The adults of Eupteryx vanduzei are $2 \frac{1}{2}$ millimeters long, and are slender with a pointed head. The head, the thorax, and the apical part of the wings are brown, and the central part of the body and of the wings is greenish yellow. One nymph was taken on Crataegus punctata foliage, and the adult emerged on August 15. The species is rarely found. 
vulgaris $\mathrm{Fb}$., Lamenia

The adults of Lamenia vulgaris are 4 millimeters long, bluish gray, and rather stout. They are abundant on native hawthorns during the last half of June.

\section{Membracidae}

crataegi Fitch, Glossonotus (Hawthorn tree hopper)

The adults of Glossonotus crataegi are fairly common on the branches of native hawthorns' during July and early August.

flavicephala Goding, Ophiderma

The adults of Ophiderma flavicephala are 8 millimeters long, are brown with a yellowish white stripe on each side and across the rear end of the prothorax, and are without a hump. They are rarely found on the branches of Crataegus punctata and $C$. tomentosa during June.

tauriná Fitch, Ceresa

The adults of Ceresa taurina are 8 millimeters long, are pale green, and have the prothorax prolonged into a horn on each side of the head. They are found occasionally on the branches of Crataegus punctata and $C$. neofluvialis in late July and August. No nymphs were reared to the adult stage on Crataegus, but several nymphs answering the description of this species as given by Hodgkiss (1910) hatched on April 20 and lived through three instars on Crataegus punctata foliage.

\section{Aphididae}

corrugatans Sir., Pemphigus (Woolly thorn aphis)

A few colonies of the flocculent greenish aphids of the species Pemphigus corrugatans were found in early June on Crataegus punctata. They live on the under side of the leaves and curl the leaf margins downward.

crataegi Monell, Macrosiphum

The apterous females of Macrosiphum crataegi may be found from late May until October on the native hawthorns at Ithaca, and during July and August the species may become so abundant as to seriously injure the

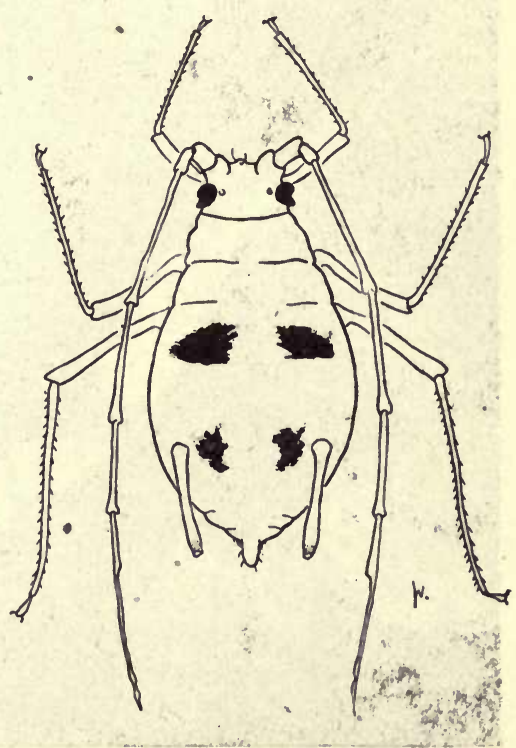

Fig. 108. MaCrosiphum GRATAECI 
trees. During the summer of 1919 the writer saw a small Crataegus pruinosa tree killed and a very large $C$. punctata tree almost entirely defoliated due to the sucking of sap by myriads of these aphids. They are rather large, yellowish green aphids, with long cornicles, and their most easily recognizable character is the presence of four dark green spots - arranged in a rectangle on the dorsal side of the abdomen (fig. 108). The entire life history is passed on Crataegus trees. The black winter eggs are placed on the twigs and the smaller branches. They begin to hatch in May, after the leaves are well opened. The young aphids move to the lower surface of the leaves, and their feeding, as the colony increases, causes the leaves to curl downward.

In late June an alate brood appears and migrates to near-by branches or trees to start new colonies. It is after this brood appears that the species becomes so injurious.

\section{crataegifoliae Fitch, Aphis}

In early May, 1918, the Crataegus coccinea trees at Ithaca began to show the terminal rosettes of curled leaves caused by Aphis crataegifoliae. The rosettes turned red, and the aphids within them also were red. The infested

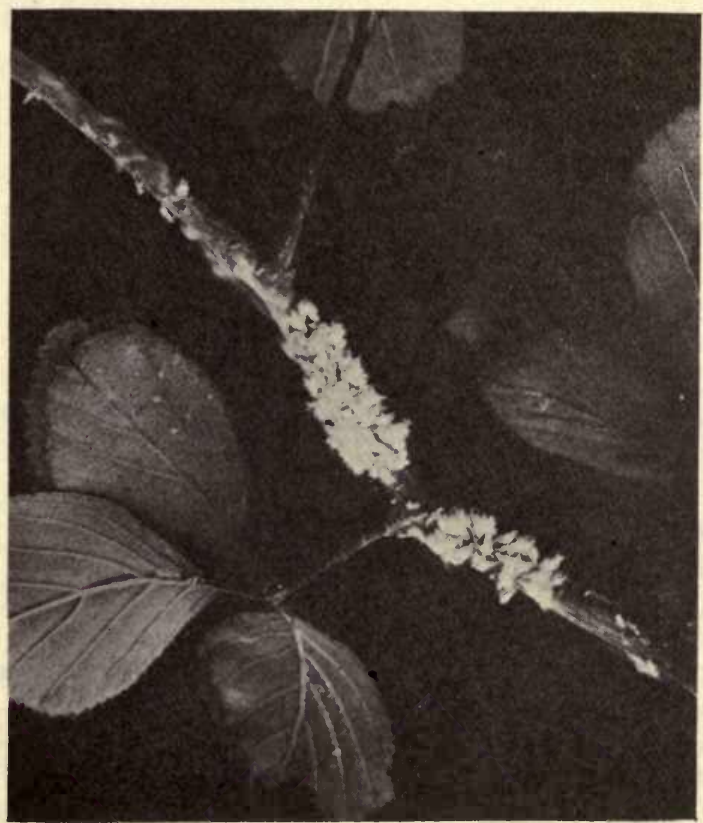

Fig. 109. eriosoma LANIGERA ON HAWTHORN branches remained deformed and somewhat stunted throughout the season, although the aphids departed from the trees about May 20 to seek leguminous hosts. No aphids of this species were observed the next year.

lanigera Hausm., Erioscma (Woolly aphis)

The woolly aphids first become noticeable in carly June as small white spots on the tender twigs of Crataegus. In a favorable season such as the summer of 1918 , they become very conspicuous and cover entire branches by late summer (fig. 109). The writer has not found the roots of Crataegus infested. 
pomi De Geer, Aphis (Green apple aphis)

During June and July the succulent sprouts of European and native hawthorns are badly infested by green apple aphids. Whenever the weather becomes unfavorable for their enemies they increase rapidly and infest entire trees or hedges, but fair weather checks them again.

\section{prunifoliae Fitch, Rhopalosiphum (Apple bud aphis)}

The dark green stem mothers of the species Rhopalosiphum prunifoliae begin to appear on the buds of native hawthorns as soon as the bud scales have separated enough to show the green leaves within. The colonies increase during April and early May, doing some damage to the young leaves and buds, but before June they migrate from the trees to grasses and are not often found on the trees between early June and late autumn. The winter eggs are laid on hawthorn twigs and buds.

\section{Coccidae}

corni Bouché, Lecanium (European fruit lecanium)

The species Lecanium corni is often very abundant on the lower side of branches of native hawthorns, and occasionally a branch is found to be almost entirely covered with these scales. Lower or inner branches that receive a scanty supply of light appear to be killed by them. The young, flat scales are sometimes very plentiful on the leaves in late summer.

furfura Fitch, Chionaspis (Scurfy scale)

The flat, whitish scale known as Chionaspis furfura is very common and noticeable on the bark of all Crataegus species which the writer has observed. The small, elongate, white, male scales are often very abundant on the leaves and bark of Crataegus punctata. The injury caused by these scales is not noticeable.

perniciosus Comst., Aspidiotus (San José scale)

Although the San José scale is fairly common on all species at Ithaca, it does not seem to increase rapidly enough to become injurious. It is more commonly found on the smooth bark of young trees than on old, rough-barked trees.

ulmi Linn., Lepidosaphes (Oyster-shell scale)

The oyster-shell scale is common on the bark of native and European hawthorns, and a few badly infested branches have been found. Generally, however, this species seems to be unimportant as a pest of Crataegus. vitis Linn., Pulvinaria (Cottony scale)

The species Pulvinaria vitis is occasionally found on the twigs and branches of native hawthorns, but is not very abundant. 


\section{THYSANOPTERA}

tritici Fitch, Euthrips

\section{Thrypidae}

Nymphs and adults of Euthrips tritici are very common in flowers and flower buds of native hawthorns in April and May. Many flower buds fail to open, and inside of them are found from one to a dozen or more of these thrips. They were exceedingly abundant in the Cornell University arboretum in 1918, and very few hawthorns there bore fruit that year.

\section{COLEOPTERA}

dubitans Lec., Limonius

\section{Elateridae}

The beetles of the species Limonius dubitans occasionally are found eating leaves of native hawthorns in late May and early June. On May 31,1919 , one of these click beetles was found on a Crataegus pruinosa leaf where it had been feeding, and was attacked by an adult pentatomid, Apeteticus madestus Dallas. The latter had its beak inserted into the beetle, which died while being carried to the laboratory.

pubescens Melsh., Agriotes

The beetles of Agriotes pubescens were eating the leaves of Crataegus punctata on May 23. The species is not common.

\section{Melanotus sp.}

The beetles of Melanotus sp. were eating the leaves of Crataegus punctata on June 6 and June 8. The species is not common.

aerosus Melsh., Brachys

\section{Buprestidae}

The beetles of Brachys aerosus were found feeding on Crataegus punctata leaves in warm sunlight from May 30 to June 20. There were commonly two or three to a leaf, feeding on the upper surface and cutting small holes through the leaf. As many as fifty of the beetles were found on one tree, while neighboring trees had none. They are from 4 to 5 millimeters long, and are brown and gold in color.

elongata'Fabr., Dichelonycha

\section{Scarabaeidae}

The beetles of Dichelonycha elongata were found feeding on Crataegus punctata foliage, six being seen on one tree on May 31. A seventh beetle was killed by three adult pentatomids of the specias A peteticus modestus, which were feeding on its body. 
testacea Kirby, Dichelonycha

The beetles of Dichelonycha testacea were found on Crataegus tomentosa foliage on May 29 and July 1. They cut irregular patches from the edge of the leaf. The species is not common.

\section{borealis Shev., Dibolia}

\section{Chrysomelidae}

The green flea beetles of the species Dibolia borealis are $2 \frac{1}{2}$ millimeters long. They feed on native hawthorn foliage in May, as soon as it is expanded. They hibernate beneath bark scales on the trunk and the branches, and when warmed in the hand in February they very soon become active.

carinata Germ., Haltica

The metallic violet or green flea bretles of the species Haltica carinata are 4 millimeters long. They feed on foliage of native hawthorns in June. They are not common.

cucumeris Harris, Epitrix

Tiny shining bluish beetles less than $\dot{2}$ millimeters long, of the species Epitrix cucumeris, were found feeding on Crataegus punctata foliage in June. The species is not common.

helxines Linn., Crepidodera

The shining greenish flea beetles of the species Crepidodera helxines are 3 millimeters long. They feed on the foliage of native hawthorns and are frequently so numerous as to cause considerable injury. They are found feeding in May, June, July, and August, but are most abundant in late May and in June. The beetles hibernate under bark scales on the trunk and the larger branches, where many of them die from the attack of a white fungous growth before spring.

marginalis Ill., Systena

Yellowish brown, slender flea beetles 4 millimeters long, of the species Systena marginalis, were found in August and early September eating holes in leaves of native hawthorns. The species is fairly common.

\section{villosula Melsh., Xanthonia}

The stout brownish or black beetles of the species Xanthonia villosula are 4 millimeters long. They were found feeding on the leaves of Crataegus punctata from late June to early August. Occasionally they are so abundant as to completely riddle the foliage of a tree with the holes they cut in feeding (Wellhouse, 1919). Feeding punctures are shown in figure 110 , on the following page. 


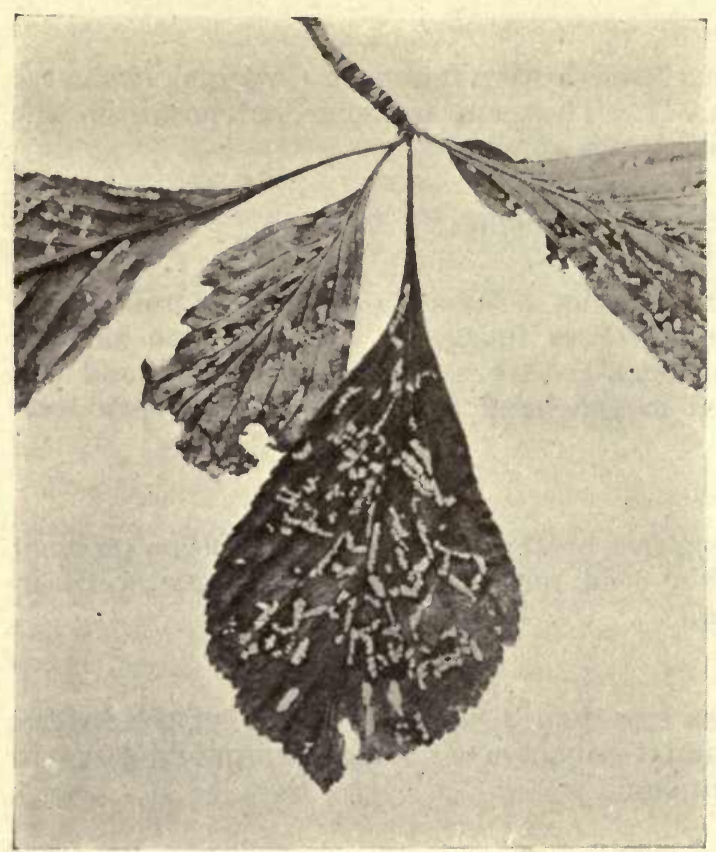

Fig. 110. FEEDING PUNCTURES OF XANTHONIA VILLOSULA IN LEAVES OF CRATAEgUS PUNCTATA

\section{Curculionidae}

crataegi Walsh, Conotrachelus (Quince curculio)

The square-shouldered brown beetles of $C o n o-$ trachelus crataegi were found puncturing the fruit of Crataegus for feeding and oviposition in July and August, 1918, and in late May and June, 1919. The early months of 1919 were much warmer than those of 1918 at Ithaca, and this probably is the cause of the great variation in the time of their appearance. The larvae develop within the haws, feeding on the pulp surrounding the large, stony seeds. A larva commonily eats about one-half of the entire pulp of the fruit before emerging in the autumn, when it leaves the fruit by a large, round, exit hole. It then burrows down two or three inches in the soil and spends the winter as a larva curled in a smooth-walled earthen cell. In June, 1918, the writer found ninety-six larvae in the soil beneath one Crataegus punctata tree. Some of them pupated in June and others in July. They are very common on all the native hawthorns.

nebulosus Lec., Anthonomus (Hawthorn blossom weevil)

One of the most interesting and injurious of the insects found on the hawthorns is Anthonomus nebulosus, a member of a very destructive genus of blossom weevils. Its mode of life resembles in a general way that of the Mexican cotton boll weevil, $A$. grandis, and is almost identical with that of the European apple-blossom weevil, A . pomorum (Theobald, 1909: 104-110).

The original description of $A$. nebulosus is to be found in the Proceedings of the American Philosophical Society (Leconte, 1876), and a more complete description is given by Dietz (1891). In the present account it is 
sufficient to say that $A$. nebulosus is a brown or grayish oval beetle, from 3.75 to 4.25 millimeters long, generally with a whitish, V-shaped mark on the fore part of the elytra, with a long, slender, curved beak, and the front femur having two teeth on its apical part, one large and the other small (Plate LXXIV, page 1070).

The species has been found in New York, New Jersey, Michigan, Indiana, Missouri, Arkansas, and Louisiana, and therefore it seems probable that it is present wherever its hosts are found east of the Rocky Mountains. Although Dietz considers this species to be more characteristic of the European fauna than of our own, no record can be found of its occurrence in Europe or elsewhere outside of this country.

Its hosts include a number of the larger-flowered species of hawthorns, such as Crataegus punctata, $C$. brainerdi, $C$. pruinosa, and $C$. mollis. The smaller-flowered species, such as $C$. oxyacantha, are not selected by the beetles for oviposition, probably because there is not space enough for the full development of the larva within the bud.

The injury caused by the hawthorn blossom weevil is most apparent while the trees are in full bloom. At that time the infested blossoms are brown and remain closed. On badly infested trees fully fifty per cent of the blossoms may be in this condition and the trees present a scorched appearance. As the young fruit begins to set, the infested blossoms commonly fall to the ground, but they may sometimes be seen on the trees even after the beetles have emerged in June.

The beetles come out of hibernation and appear on the branches of the hosts about mid-April, feeding ravenously on the buds, which are showing green. It is not uncommon to see a beetle with feet braced and beak inserted up to the eyes in a bud while it hurriedly eats the tender leaves within. As soon as all the food within reach of the entrance hole is eaten, the beetle seeks another bud on the twig and repeats the process. The puncture in the bud is round, is 0.3 millimeter in diameter, and turns dark as soon as the beak is withdrawn. The presence of the beetles may be detected by these dark round holes in the buds before the egg-laying period arrives. The beetles continue to feed on the buds during suitable weather until the clusters have separated enough for oviposition in the blossoms.

During cool weather the beetles remain inactive, generally in the axils of the twigs with their heads down. A few observations on the relation of temperature to their activities were made, and these indicate that the beetles remain inactive while the temperature is below $50^{\circ} \mathrm{F}$. The optimum temperature is from $60^{\circ}$ to $70^{\circ}$, and when it is raised to $78^{\circ}$ the beetles rush about like mad, attempting to oviposit in every bud. Under most conditions they seem reluctant to fly, but when placed on distasteful food they fly away. They continue their activities on cloudy or rainy days and at night if the temperature is sufficiently high. 


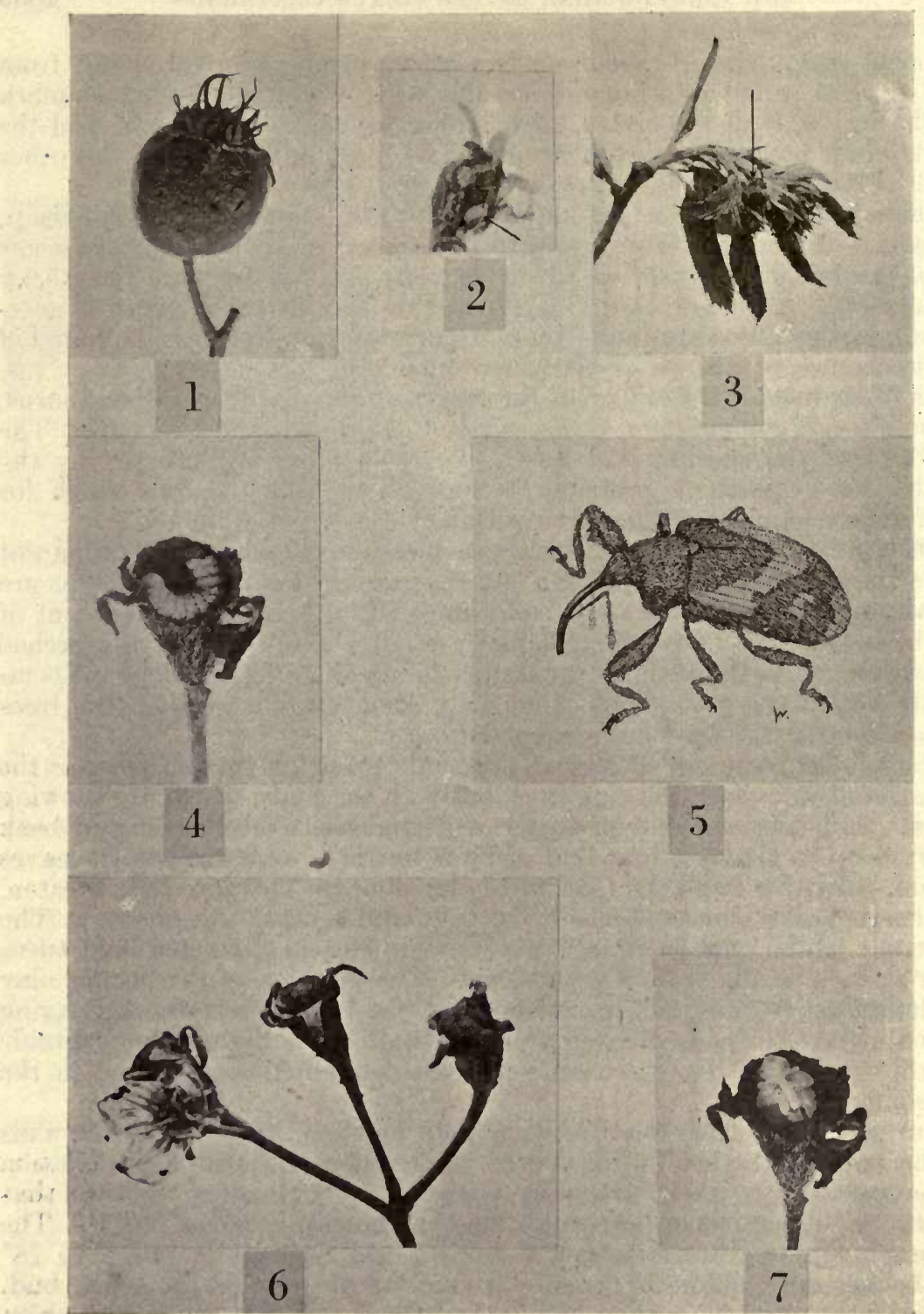

\section{ANTHONOMUS NEBULOSUS}

1. Feeding punctures of beetles in hawthorn fruit. 2, Egg in blossom/bud. 3, Female ovipositing in blossom bud. 4, Flower with petals removed to show full-grown larva in its natural position. 5, Actult beetle. 6, Three flower buds containing larvae, and one normal blosson. 7, Flower with petals removed to'show pupa in its natural position 
The period between the opening of the blossom clusters and the opening of the blossoms themselves is the time of oviposition, and the length of this period probably influences the amount of injury to a considerable extent. If it is prolonged by cool, cloudy weather, then eggs may be placed in more of the blossoms before they open. In central New York the oviposition period is about May 15.

After selecting a suitable blossom bud, the female makes a hole in the side of the calyx with her beak. Then, turning around, she thrusts the egg into the hole with her ovipositor, and moves to another bud to repeat the process. A clear liquid fills the hole where the egg is thrust in, which soon hardens and seals the opening completely. The act of oviposition requires about ten minutes when the temperature is $68^{\circ}$ or $70^{\circ}$, but it requires an hour at $54^{\circ}$.

The egg is pearly white, 0.6 millimeter long, 0.36 millimeter wide, elliptical, generally the same size at both ends but when tucked in tightly between the anthers it may be narrower at one end to conform to the space it fills. It is of almost the same size and color as the anthers and is difficult to distinguish from them. The corium is smooth, unsculptured, and delicate, drying and collapsing when exposed to the air for one hour.

After about a week the young, white, curved, legless larva is found within the bud. It feeds on the anthers, and, as it grows, consumes all the internal parts of the flower but leaves intact the wall of the receptacle and the closed petals which form the roof of its house. The petals become stiff as if they were starched, and do not shrink away as they turn brown. After feeding for a couple of weeks the larva is dirty white, is from 6 to 8 millimeters long, is still legless, has a small brown head, and lies in a curved position. At about this time it molts and changes to a white, free pupa 6 millimeters long, with a dark caudal spine, two dark prominent spines on the apex of the head, and several smaller spines farther back on the head. After pupating during a week or a little longer, the beetle makes a hole in the top or the side of its house with its beak, and emerges.

It begins to feed a few minutes after emergence, choosing for its food the first young thorn or fruit in its pathway as it wanders along the branch. The thorns of the current season's growth seem to be a very attractive food. A hole is drilled near the base of the thorn, and the beetle spends hours with its beak inserted in the hole completely up to its eyes, prying and straining to enlarge the cavity within the thorn. The round hole at the base of a thorn does not heal during the season's growth, and the presence of such holes will indicate at any time of the year the presence of the blossom weevils. The beetles attack the fruit also and make several round holes in a single fruit before seeking another. The holes become brown almost immediately. The writer has never found 
the beetles eating leaves or tender twigs, but they sometimes feed on the succulent globular leaf galls of cecidomyiid larvae. They will puncture and feed on young apples in the cages when fresh haws are not to be had, but the writer has found none feeding on apples in the field.

After feeding for a week or ten days the beetles may be found in copulation on the branches, and a week or so later, as warm July weather comes, they disappear from the trees. Those kept in breeding cages remained hidden in fallen curled leaves and hollow twigs on the ground all summer and winter without feeding until the next spring. A search for their hiding places in the field revealed a score of the beetles inclosed in ourled, dried leaves on the ground beneath their host trees.

The life cycle may be summarized as follows: The immature stages (egg, larva, and pupa) are completed within the closed blossom in from twenty-seven to thirty-five days, and the remainder of the year is passed in the adult stage. The adults feed on thorns and fruit for two or threc weeks after emerging from the blossoms, and then remain quiescent among fallen leaves on the ground until the next spring, when they feed for about a month on the buds before ovipositing. Soon after oviposition the beetles die. In New York the eggs are laid about mid-May and the beetles emerge from the blossoms in June. W. D. Pierce, in a letter to the writer, says the beetles emerge in late March and early April in Louisiana. The time of their development in different latitudes is dependent on the opening of the hawthorn blossoms in those latitudes.

A number of natural enemies of the blossom weevil have been observed. Various birds, especially sparrows, pick open the brown blossoms to eat the larvae and the pupae. Pierce (1912:77) found the weevils to be parasitized by Catolaccus hunteri and Sigalphus sp. The writer has bred another chalcid, Habrocytus piercei Cwfd., from the larva of the weevil, the adult parasites emerging on June 16 and 17.

quadrigibbus Say, Tachypterus (Apple curculio)

The four-humped brownish beetles of the species Tachypterus quadrigibbus were found occasionally feeding on the fruit of native hawthorns in June. Fruits of Crataegus punctata were put into rearing cages on June 25, and from these fruits five adults of this species emerged on July 15 and July 18.

\section{LEPIDOPTERA}

\section{Papilionidae}

turnus Linn., Papilio (Tiger swallowtail)

The green larvae of Papilio turnus, with their peculiar eye spots, were found feeding on the foliage of native hawthorns from June 20 to August 2. The species is not very common. 


\section{Saturniidae}

io Fabr., Automeris

The eggs of Automeris io are not uncommon on the under side of hawthorn leaves in late June and in July. They are very characteristic and conspicuous. A cluster of eggs may consist of a dozen or more; each large and creamy white with a dark blue dot on the distal end. The larvae feed in colonies on the foliage during July, August, and September. They are at first dark, then green, and are always covered with a mass of dark, stinging spines.

\section{Arctiidae}

caryae Harris, Halisidota (Hickory tussack moth)

The black-and-white-tufted caterpillars of the species Halisidota caryae are fairly common on native hawthorns during August.

tesselaris A. and S., Halisidota

The caterpillars of Halisidota tesselaris are similar to those of $H$. caryae and are found occasionally on the foliage with them, but are not so common.

textor Harris, Hyphantria (Fall webworm)

A single colony of larvae of Hyphantria textor was feeding on Crataegus pruinosa on July 31, 1918. An egg cluster which was probably of this species hatched on June 19, and the young larvae fed on C. punctata leaves for a few days and then died.

americana Harris, Acronycta

\section{Noctuidae}

The larvae of Acronycta americana are green, with an abundant covering of yellowish white hairs and a few long pencils of black hairs. They were found feeding on the leaves of native hawthorns in late June and July. The species is not common.

\section{dactylina Grote, Acronycta}

The larvae of Acronycta dactylina are entirely covered with yellowish white hairs and have three long pencils of black hairs. They were feeding on the foliage of Crataegus punctata from August 15 to September. The species is not common.

luteicoma G. and R., Acronycta

The larvae of Acronycta luteicoma are black, with tufts of white hairs on segments 3 to 6 and tufts of black hairs on the other segments. They were found feeding on Crataegus punctata leaves from June 23 to July 22. The species is not common. 
occidentalis G. and R., Acronycta

The larva of Acronycta occidentalis is hairy, with a dark head and dorsal stripes. The remainder of the body is at first whitish but in later stages is reddish. Larvae of this species were feeding on Crataegus punctata foliage from August 13 to September. The species is not common.

pyramidoides Guen., Amphipyra

The larva of Amphipyra pyramidoides is green, with a white dorsal and two yellow lateral stripes, and is found feeding on native hawthorn leaves in May. One larva constructed a silken cocoon among dead leaves on the ground on June 2 and the moth emerged on July 18. The species is not common.

\section{radcliffei Harv., Acronycta}

The larva of Acronycta radcliffei is greenish or black, has a dorsal line of green or brown with faint yellow and red lines, has a hump on segment 12 , and is sparsely hairy. It feeds on the leaves of Crataegus punctata from June 29 to July 22 . The species is not common.

superans Guen., Acronycta

The larva of Acronycta superans is green, with a black dorsal line widened into a spot on several abdominal segments and with the last segment angularly elevated. There are few hairs on the body. It was feeding on Crataegus punctata leaves from June 9 to July 1, and pupated in a silken cocoon among leaves and decayed wood on the ground. The moth emerged on July 23. Only one larva was found.

\section{Notodontidae}

concinna A. and S., Schizura (Red-humped apple caterpillar)

The brownish, red-humped larvae of Schizura concinna feed on leaves of native hawthorns during July, August, and early September. Occasionally they defoliate several branches of a tree, but they are not generally injurious as is Datana ministra. They seem to prefer apple to hawthorn. On July 27, 1918, a count was made of the infested trees in several thickets where seedling apples and hawthorns were growing together. Although the hawthorns were much more numerous than the apples, the latter had forty-six infested trees while the former had only three.

\section{manteo Doub., Heterocampa}

The larva of Heterocampa manteo is bright green marked with red. It was found feeding on the foliage of native hawthorns in late June and in July. The species is not very common. One larva taken from a Crataegus punctata tree on August 15 continued to feed in the cage until September 2 , when it wandered away to find a suitable place for spinning its cocoon. 


\section{ministra Dru., Datana (Yellow-necked apple caterpillar)}

One of the most destructive species to both native and European hawthorns during the past few years has been Datana ministra. Very few trees have escaped without at least one colony of these yellow-necked, black-bodied, gray-haired caterpillars feeding on a branch in July and August. Many trees have had an entire branch stripped bare of leaves, and occasionally a whole tree has been defoliated.

The light brown moths appeared and were found ovipositing during June and July. The clusters of white eggs, each cluster containing from 25 to 100 , were deposited on the lower side of the leaves and were a common sight in July. The larvae of a colony begin to feed at the tip of a branch and migrate toward its base as they grow, leaving the bare branch behind them. As they become larger they scatter to adjacent branches and feed singly or by twos and threes. They become full-grown and enter the soil in September.

Several observations were made to determine whether the larvae prefer hawthorn to apple. When confined in cages they eat one as readily as the other. In the natural uncultivated areas where hawthorn, apple, and pear grow wild, however, it was noticed that the colonies of larvae were commoner on hawthorn than on the other trees. In one field containing 50 hawthorn, 39 apple, and 17 pear trees, 79 colonies of larvae were counted. Of these colonies 56 were on hawthorn, 15 on apple, and 8 on pear.

\section{Lymantriidae}

leucostigma A. and S., Hemerocampa (White-marked tussock caterpillar)

The larva of Hemerocampa leucostigma, with its bright red head, its red tubercles on segments 6 and 7 of the abdomen, its four white tussocks, and its three long, black pencils of hairs, is a common sight on both native and European hawthorns. It feeds on the foliage during June and July, and the hairy cocoons are common on the branches in winter.

\section{Lasiocampidae}

americana Harris, Epicnaptera

The large larva of Epicnaptera americana is gray with white spots and two red bands above, and orange with a row of lateral diamond-shaped black spots below. It feeds at night on Crataegus punctata foliage in July and August, The species is not common.

americana Fabr., Malacosoma (Apple tent caterpillar)

During the years 1917 to 1920 , only the old egg masses of Malacosoma americana were found on the twigs of hawthorns about Ithaca. Only two colonies of larvae were seen on the favorite host, wild cherry, and only one colony on apple. 
cognataria Guen., Lycia

\section{Geometridae}

The larva of Lycia cognataria is green and is $4 \frac{1}{2}$ centimeters long. It has two pairs of prolegs. On its head are blunt horns, and it bears a prominent red tubercle on the next to the last segment. It feeds on Crataegus punctata and $C$. pruinosa foliage in July. It is not a common species.

magnarius Guen., Ennomios

A moth of Ennomos magnarius emerged from a brown silken cocoon on a twig of Crataegus pruinosa on September 30. Eggs were found on a C. punctata twig on November 12 . The brownish larvae, 5 centimeters long, were found occasionally in May and June.

pometeria Peck, Alsophila (Fall cankerworm)

The small greenish or brownish larvae of Alsophila pometeria are fairly common on native hawthorns in May.

subsignarius Hüb., Ennomos

The white moths of Ennomos subsignarius emerged on July 6 and July 18 from pale yellowish pupae which were found tied with silk between the leaves of Crataegus punctata. A few of the brown and red larvae were found feeding on the foliage of native hawthorns in May.

tiliaria Harris, Erranis (Lime-tree spanworm)

The yellow-and-black-striped larvae of Erranis tiliaria are common on native hawthorn foliage in May and June.

titea Cram., Phigalia

Two larvae of Phigalia titea were found feeding on Crataegus punctata leaves on June 2 and June 5.

vernata Peck, Paleacrita (Spring cankerworm)

The larvae of Paleacrita vernata are common on foliage of native and European hawthorns in May and early June.

scitula Harris, Sesia

\section{Sesiidae (Aegeriidae)}

A single Crataegus punctata tree about eight years old and 5 feet high was killed by the larvae of Sesia scitula. The trunk was entirely girdled by four larvae which tunneled beneath the bark two inches above the soil. The sapwood was only slightly indented by their burrows around it. They pupated during June in silken cocoons covered with frass within the burrows, and the moths emerged from July 18 to July 24 . In emerg- 
ing, the moth pushes through one end of the cocoon, and then sheds the pupal skin while protruding about two-thirds of its length beyond the cocoon. The black, clear-winged moth has a broad and a narrow band of yellow across the abdomen.

\section{Pyralidae}

indigenella Zell., Mineola (Leaf crumpler)

The cornucopia-like winter cases of Mineola indigenella, a leaf crumpler, are easily seen on almost any hawthorn tree during the winter, attached firmly to the twigs and the branches and often with partly eaten leaves attached. The larvae carry the cases with them and feed on the leaves in April and May. They pupate within the same cases attached to twigs in June, and at Ithaca the moths emerge in late June.

\section{Tortricidae}

\section{argyrospila Walk., Archips (Fruit-tree leaf roller)}

The greenish larvae of Archips argyrospila, with their black heads and shields, are fairly abundant on the foliage of native hawthorns during May and are found occasionally in June. They tie together a cluster of leaves and feed on a leaf within the cluster. Moths emerged from the larval nests in late June and early July.

\section{chionosema Zell., Olethreutes}

The pale green larvae of Olethreutes chionosema.fold the leaves of native hawthorns and feed on the upper surface of the leaves within the fold. Each larva folds a single leaf at a time. They are fairly common on the hawthorns and apple trees about Ithaca during May. The moths fly during June after pupating within the folded leaf. A few moths taken on August 14 and 15 seem to indicate a second brood. The moth (fig. 111) is brownish, with a large white spot on the costal edge of the fore wing, and has a wing expanse of from 15 to 16 millimeters.

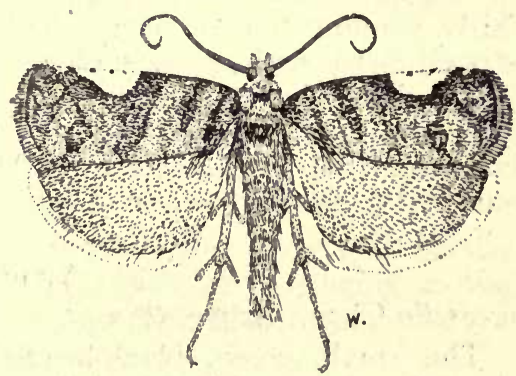

Fig. 111. olethreutes ChIONOSEMA nubeculana Clem., Ancylis

The greenish larvae of Ancylis nubeculana were found in late summer in rolled leaves of Crataegus punctata. They pupated in May and the moths emerged from June 8 to June 18. The species is not very common. 
ocellana Fabr., Tmetocera (Bud moth)

The brownish larvae of Tmetocera ocellana are commonly found in the partly opened leaf buds in April and May, on both native and European hawthorns. The moths emerge from the larval nests in June and early July.

prunivora Walsh, Laspeyresia (Lesser apple worm)

The small white caterpillars of Laspeyresia prunivora are very common in the fruit of many native hawthorns in late summer. They eat most of the pulp from one side of the fruit, causing the skin to sink in there. The larvae of the second generation sometimes remain in the fruit all winter, living within a mixture of silk and pellets of frass. Others spin silken hibernacula under the bark of the trunk very similar to those of the codlingmoth larvae but smaller. They pupate within the hibernacula in the spring and the moths emerge in May and June. In the laboratory they emerged in March. Moths of the first generation were taken in the field from August 15 to August 30.

quadrifasciana Fern, Eulia

The yellowish larvae of Eulia quadrifasciana tie together with silk the leaves of terminal clusters on Crataegus punctata in May. They pupate within the larval nests and the moths emerge in early June. The moth is yellow and orange, with darker oblique bands on the fore wings. The species is not very common.

rosaceana Harris, Cacoecia (Oblique-banded leaf roller)

Clusters of leaves tied together by the larvas of Cacoscia rosaceana are fairly common on all native hawthorns in May and July. The greenstriped larva, with its brown head and shield, is generally found on a single leaf under a slight web, feeding on one side of the leaf only. When fullgrown the larva ties a cluster of leaves together to pupate within. Moths emerged from these nests from May 26 to June 30, and a second brood emerged from August 1 to August 15.

\section{oreasella Clem., Argyresthia}

\section{Yponomeutidae}

The small, green, black-headed larva of Argyresthia oreasella bores. through a terminal leaf bud down into the twig and makes a hole in the side of the twig about $\frac{1}{2}$ inch from the tip, through which the frass is cast out of the burrow. When disturbed the larva runs quickly out of either the hole in the twig or the hole in the bud, to escape. Infested twigs wilt soon after the larva has. left the burrow, and then become brown and dry, giving the tree a fire-blighted appearance (fig. 112). Larvae of this species were found in many native hawthorn twigs in May. They leave the 
twigs when full-grown, and spin a parchment-like white cocoon surrounded by an open layer of lacework attached to the surface of a leaf. The moths emerged from June 15 to June 30. A few moths taken in the field on August 16 seem to indicate a second brood. The moth is slender, and is white with oblique gold bands on the fore wings while the hind wings are dark gray. Its wing expanse is about 13 millimeters. It has a peculiar habit of standing on its head when at rest on the leaves or the bark.

\section{Elachistidae}

fletcherella Fern., Coleophora (Cigar case-bearer)

The brown, cigar-shaped cases of the larvae of Coleophora fletcherella are common on all the hawthorns throughout the growing season. They have been specially abundant

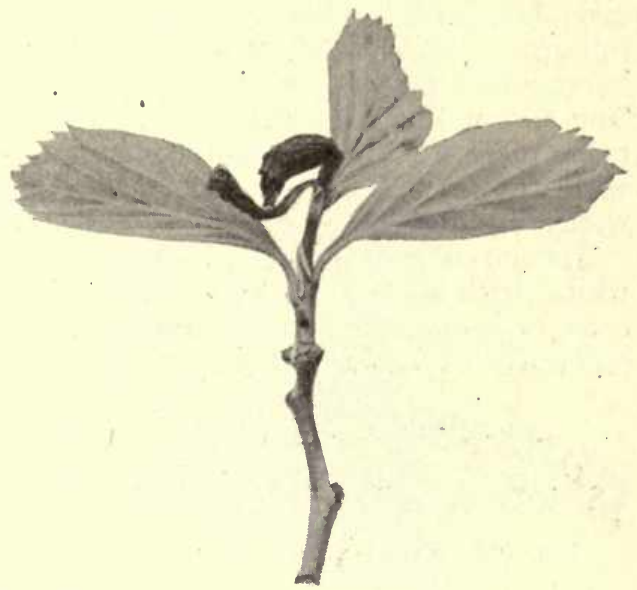

Fig. 112. TERMINAL OF HAWTHORN TWIG DESTROYED BY LARVA OF ARGYRESTHIA OREASELLA

and injurious on trees and hedges of Crataegus oxyacantha, the European hawthorn, during the years 1918 and 1919. The moths emerged from the cases in late June and July.

malivorella Riley, Coleophora (Pistol case-bearer)

The curved cases of the larvae of Coleophora malivorella are fairly common on hawthorns but not so abundant as those of $C$. fletcherella.

splendoriferella Clem., Coptodisca (Resplendent shield-bearer)

The small, yellowish brown, winter shields of Coptodisca splendoriferella are rather commonly found attached to the bark and swinging in the wind on the branches of native hawthorns, and their blotch mines in the leaves are not uncommon.

\section{Lyonetiidae}

pomifoliella Clem., Bucculatrix (Ribbed-cocoon-maker of apple)

The elongate, white, ribbed cocoons of Bucculatrix pomifoliella are common on native hawthorns and are rather noticeable in winter, when the trees are leafless. The moths emerge in late May. 


\section{Cosmopterygidae}

curvilineella Chamb., Blastodacna (Hawthorn fruit miner)

The larvae of Blastodacna curvilineella are very commonly found tunneling in the fruit of native hawthorns in late summer. They become full-grown in September and October, when they leave the fruit and burrow into the ends of dead twigs or other decaying wood to hibernate. The hibernation cavity is lined with silk, and in the early spring pupation takes place there. The moths emerge in May and June. They are gray, with two or three indjstinct dusky longitudinal short streaks on the wings, and have a wing expanse of 1 centimeter.

The larva is from 9 to 10 millimeters long. In color it is yellowish white, with a brown head and thoracic legs, red spots near the spiracles, more or less blackish among the setae on the dorsum of each segment but especially noticeable on the prothorax and the anal segment, and many

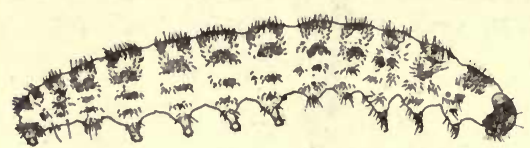

Fig. 113. LARVA OF BLASTODACNA CURVILINEELLA patches of black setae arranged as shown in figure 113. It feeds on the pulp of the fruit and leaves many brown pellets of excrement in the burrow behind it. Often one whole side of a fruit is mined out, leaving only the skin to cover it.

The moths have been bred from larvae in Crataegus pruinosa, C. neofluvialis, and C. macracantha, and the larvae have been found in a number of other native hawthorns. The moth has been reported by Chambers from Kentucky (1872) and from Canada (1875), and therefore it probably occurs throughout the Eastern States.

A closely related European species, $B$. hellerella Dup., feeds in the fruit of hawthorns and also bores into young apple shoots (page 1116).'

\section{DIPTERA}

\section{Cecidomyiidae (Itonididae)}

absnbrina Felt, Rhizomyia

crataegifolia Felt, Lestodiplosis (Hawthorn fringed-cup gall)

Adults of both Rhizomyia absobrina and Lestodiplosis crataegifolia have been reared by Dr. Felt from larvae in the galls. The galls are green and cup-shaped, and are covered externally with round-tipped spines 4 or 5 millimeters in diameter and about the same in height (figs. 114 and 115). They occur on the larger veins and petioles of leaves and on the ends of young twigs of Crataegus pruinosa and C. macracantha. Several galls are commonly found in a group on the same or adjoining leaves. Those on the leaves are on the upper side, but extend through the leaves to form a smooth, semi-globular swelling on the lower side. 


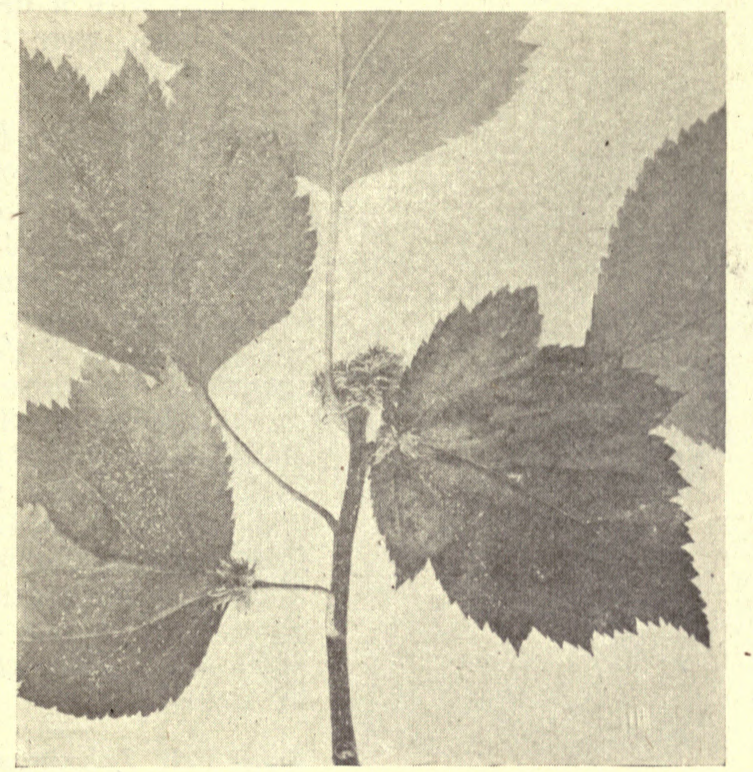

Fig. 114. HAWTHORN FRINGED-CUP GALLS

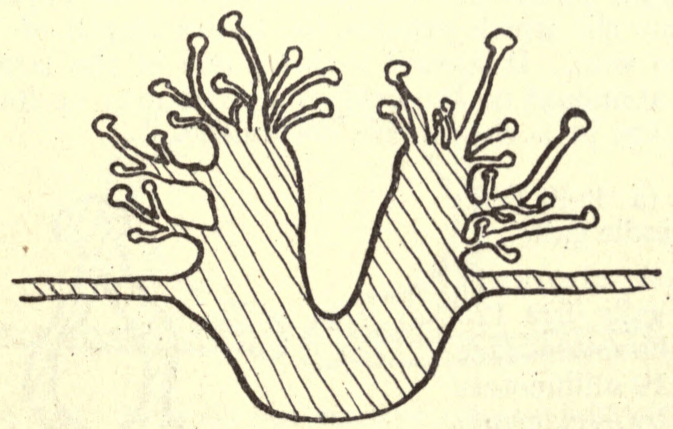

Fig. 115. CROSS SECTION THROUGH A HAWTHORN FRINGED-CUP GALL 


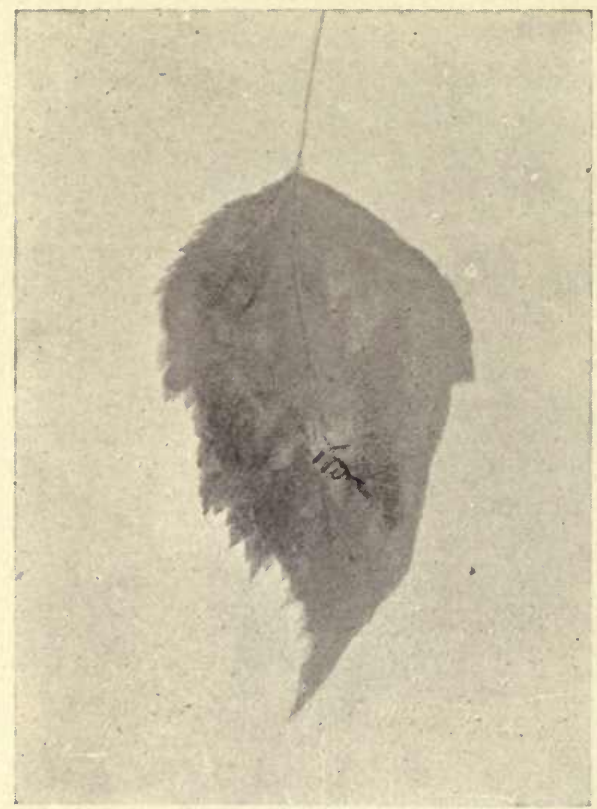

FIG. 116. THORN COCKSCOMB GALL

White larvae, 3.5 millimeters long and with a distinct brown breast-bone, were found, one in each gall, in June.

crataegifolia Felt, Hormomyia (Thorn cockscomb gall)

Green or red cockscomb-like galls (figs. 116 and 117) produced by Hormomyia crataegifolia are found on the upper or the lower side of leaves of Crataegus pruinosa, $C$. macrosperma, and $C$. coccinea. They are often in groups on a leaf or a cluster of leaves, and each gall includes a vein. The gall is from 8 to 12 millimeters long and 5 millimeters high, and is open to the outside by a long, narrow slit on the opposite side of the leaf. These galls are found in August.

venae Felt, Lobopteromyia (Thorn vein gall)

Round or oval, thick-walled, green galls (figs. 118 and 119) from 5 to 8 millimeters long, produced by Lobopteromyia venae, are found on either the upper or the lower surface of leaves of Crataegus punctata. The gall opens on the opposite side of the leaf by a narrow slit which extends the entire length of the gall in the direction of the vein. It always includes one of the larger veins. The galls are fairly abundant in June, when several may be found on one leaf and all the leaves in a cluster are deformed:

Cecidomyia sp. (a. 1840 Felt) (Thorn spindle gall)

Red or green, elongate spindle-shaped galls (figs. 120 and 121) 2 millimeters wide and from 5 to 10 inillimeters long, produced by Cecidomyia sp., are found on either side of the leaves of Crataegus punctata. The gall opens by

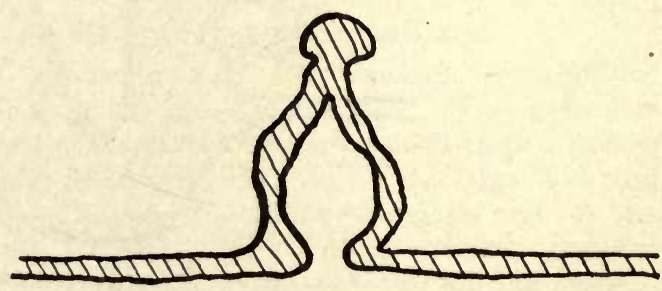

Fig. 117. CROSS SECTION THROUGH A THORN COCKSCOMB GALL 


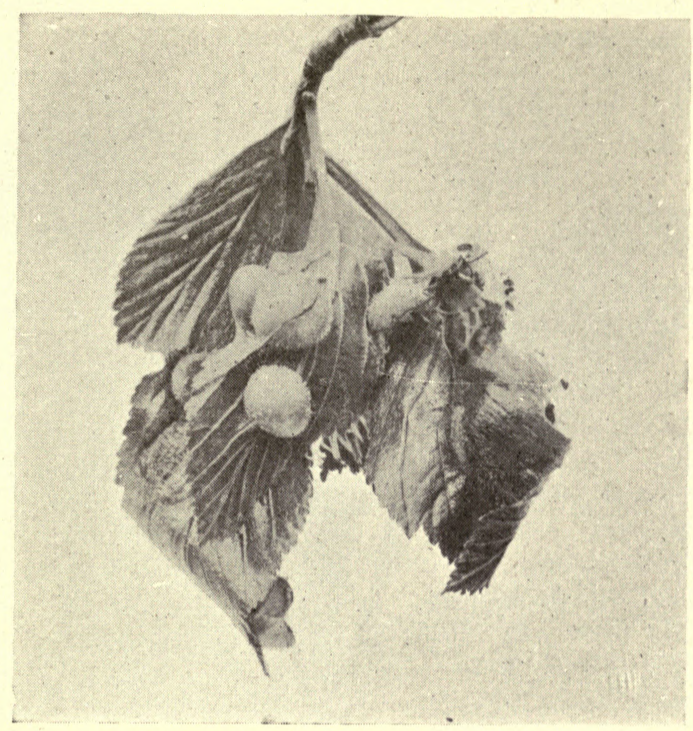

Fig. 118. THORN VEIN GALLS

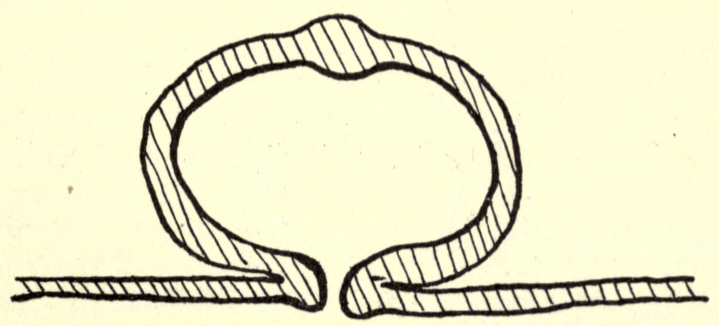

Fig. 119. CROSS SECtion through a thorN vein Gall 


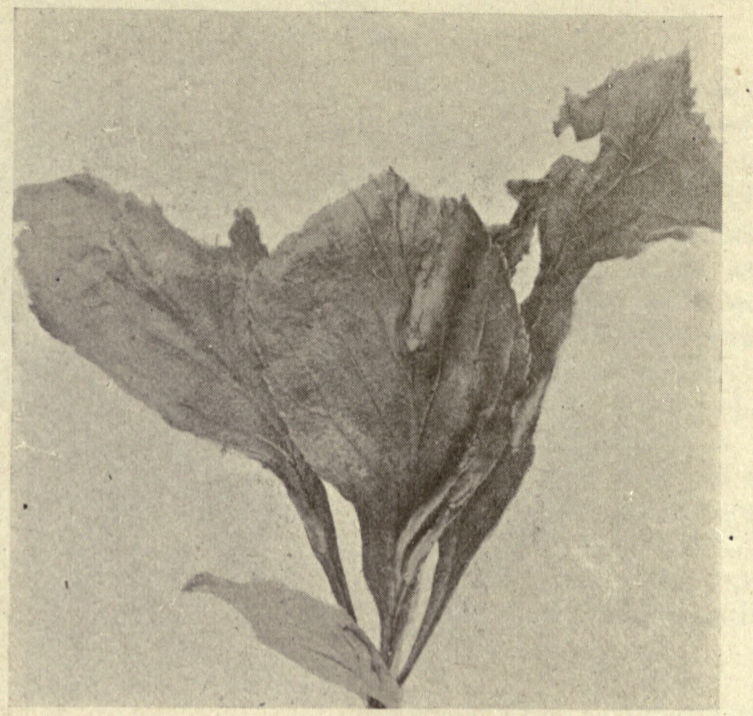

Fig. 120. THORN SPINDLE GALLS

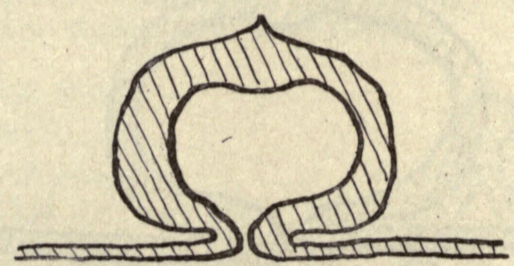

Fig. 121. CROSS SECTION THROUGH A THORN SPINDLE GALL 


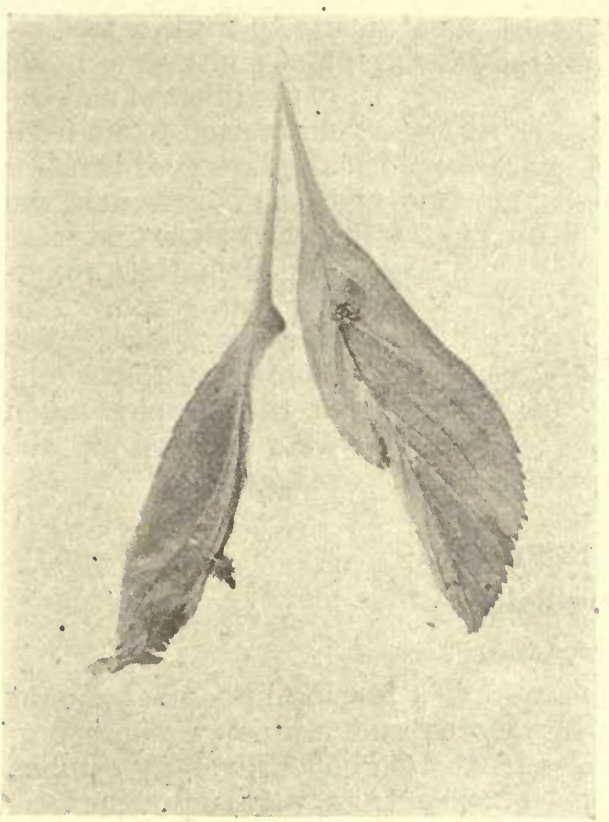

Fig. 122. Pineapple Galls

a long, narrow slit on the opposite side of the leaf. These galls occur very commonly in groups on the same leaf or on adjoining leaves. A single yellow larva, 1 millimeter long, and slender, is found in each gall in July or August.

Pineapple gall (maker unknown)

Red or green spiny galls, shaped and armored like a pineapple (figs. 122, 123, and 124), 3 millimeters in diameter and 5 millimeters high, are found on the upper side of Crataegus punctata leaves in July and August. The pineapple gall is thick and is covered with fleshy spines at the base, but becomes slender, with long, slender spines, toward the apex, which is composed of two flat, leaflike, vertical plates. The gall opens between these two plates. Generally but one gall is found on a leaf and it is commonly on the midvein.

\section{Trypetidae}

pomonella Walsh, Rhagoletis (Apple maggot)

The maggots of Rhagoletis pomonella have been reared and flies obtained from the fruits of Crataegus punctata, C. albicans, C. pruinosa, C. brainerdi, and $C$. macrosperma. 'The species probably' lives also in the fruits of other large-fruited haw th orns. No larvae have been found in the small fruits of $C$. neofluvialis and $C$. oxyacantha, although these have been carefully watched. The maggots leave the fruit to enter the ground in autumn, and the flies emerge from the brown puparia in June and July.

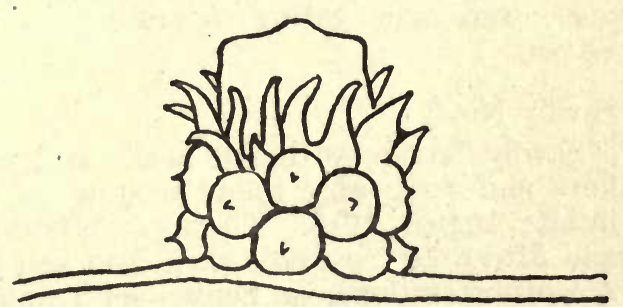

Fig. 123. SIDE VIEW OF PINEAPPLE GALL 
All of the flies reared on hawthorns are equal in size to those reared on apple, not small like those reared on the blueberry. Counts were made

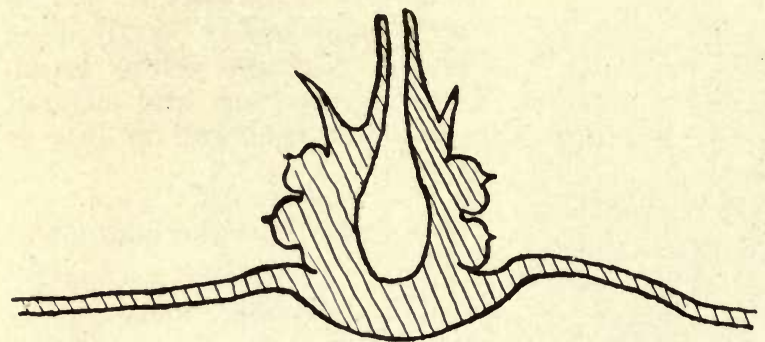

Fig. 124. Cross SEction through a PINEAPPLE GALL of the infested and the uninfested fruits from a square yard beneath each of ten trees of the three species first mentioned in the preceding paragraph. The counts showed that from 20 to 25 per cent of the samples taken were infested by the maggots.

\section{HYMENOPTERA \\ Tenthredinidae}

cerasi Linn., Caliroa (Pear and cherry slug)

The sluglike larvae of Caliroa cerasi were in a few localities so abundant that they defoliated a few native hawthorns and injured a number of others. In August, 1918, several trees on the Cornell University campus were completely defoliated, while neighboring trees were untouched by the larvae.

Sawfly No. 1

On June 23, 1918, a leaf of Crataegus pruinosa was found with a row of fourteen eggs inserted in the margin. The eggs hatched on June 28, and a row of little green larvae, with large, black heads and many black dots scattered over the body, began to feed gregariously on the edge of the leaf. All of them died within a few days.

Sawfly No 2

On May 24, 1918, several medium-sized sawfly larvae, bright green all over, were seen eating separately on the edges of Crataegus punctata leaves.

Sawfly No. 3

Sawfly larvae, with red heads and yellow bodies marked with black lines and dots, were found feeding on the leaves of Crataegus punctata in late August, 1918. They were feeding two or three together on a leaf, and fifteen larvae were taken from one tree. When they became about 2 centimeters long, on September 1 and 2, they spun brown cocoons on the ground among débris. A tree with ten larvae of the same species 
feeding on it was found on September 19, 1919, and these larvae spun cocoons on the ground on September 22 and 23.

Sawfly No. 4

A few larvae $2 \frac{1}{2}$ centimeters long, with black heads and yellow bodies marked with black lines and dots, were found feeding on the foliage of C. pruinosa in July and August, 1918. They spun brown cocoons on top of the ground, in the cages. 


\section{LITERATURE CITED}

Baker, A. C. The woolly apple aphis. U. S. Agr. Dept. Rept. 101: 1-55. 1915.

Chambers, V. T. [Blastodacna curvilineella] G.? curvilineella. N. sp. In Micro-Lepidoptera. Canad. ent. 4:172-173. 1872.

[Blastodacna curvilineella] G. bicristatella. N. sp. In Tineina from Canada: Canad. ent. 7:210. 1875.

Cushman, R. A. The native food-plants of the apple red-bugs. Ent. Soc. Washington. Proc. 18:196. 1916.

Dietz, William G. A. nebulosus Lec. In Revision of the genera and species of Anthonomini inhabiting North America. Amer. Ent. Soc. Trans. 18:203-204. 1891.

Felt, Ephraim Porter. Wild thorn. In Insects affecting park and woodland trees. New York State Mus. Memoir 82:734-735. 1906.

Gibson, Edmund H. Corythucha bellula new species. In The genus Corythucha Stal. Amer. Ent. Soc. Trans. 44:93-94. 1918.

Hodgkiss, H. E. Ceresa taurina Fitch. In The apple and pear membracids. New York (Geneva) Agr. Exp. Sta. Tech. bul. 17:100-105. 1910.

Kaltenbach, J. H. Die Pflanzenfeinde aus der Klasse der Insekten, p. 1-848. (Reference on p. 207-213.) 1872.

KNuth, Paul. Crataegus L. In Handbook of flower pollination, 2:385388. (Translated by J. R. Ainsworth Davis.) 1908.

LeConte, John L. A. nebulosus, n. sp. In The Rhynchophora of America, north of Mexico. Amer. Philosoph. Soc. Proc. 15:197. 1876.

Morrill, Austin W. Notes on the immature stages of some tingitids of the genus Corythuca. Psyche 10:127-134. 1903.

Packard, Alpheus S. Insects affecting the wild thorn. In Fifth report of the United States Entomological Commission on insects injurious to forest and shade trees, p. 532-537. 1890.

Pierce, W. Dwight. The insect enemies of the cotton boll weevil. U. S. Ent. Bur. Bul. 100:1-99. 1912. 
Theobald, Fred V. The app'e blossom weevil. In The insect and other allied pests of orchard, bush, and hothouse fruits, and their prevention and treatment, p. 104-110. 1909.

Wellhouse, Walter H. Xanthonia villosula Melsh. injuring forest trees. Journ. econ. ent. 12:396-397. 1919.

Memoir 52, Studies in Pollen, with Special Reference to Longevity, the fourth preceding number in this series of publications, was mailed on March 9, 1922. 


\section{CATALOG OF INSECTS INJURIOUS TO CRATAEGUS ${ }^{3}$}

\section{ACARINA}

armatus Can., Epetrimerus.............................Fam. Phyllocoptidae

Host - Crataegus oxyacantha.

Injury - Forms galls on leaves.

Distributio ? - Europe.

Referencss - Houard, C. Les zoocecides des plantes d'Europe, 1:515. 1908.

Theobald, F. V. Board Agr. London. Journ. 20:106-116. 1913.

calycobius Nal., Eriophyes............................. Fam. Eriophyidae

Host - Crataegus oxyacantha.

Injury - Deforms leaf buds and causes them to remain closed.

Distribution - Europe.

Reference - Ross, H. Die Pflanzengallen Mittel- und Nordeuropas, p. 132. 1911.

crataegi Can., Eriophyes........................................ Eriophyidae

Host-Crataegus oxyacantha.

Injury - Forms galls on leaves, on both upper and lower surfaces. A single leaf may have a hundred galls on it.

Distribution-Europe.

Reference - Connold, E. T. British vegetable galls, p. 132. 1902.

crataegi-vermiculus Walsh, Eriophyes......................... Fam. Eriophyidae

Hosts - Crataegus tomentosa, C. crus-galli.

Injury - Forms curled leaf galls on upper side of leaf.

Distribution - North America.

Reference - Walsh, B. D. Ent. Soc. Philadelphia. Proc. 6:227. 1866.

goniothorax Nal., Eriophyes................................... Eriophyidae

Synonyms - Erineum oxyacanthae Am., Erineum clandestinum Grev.

Host-Crataegus oxyacantha.

Injury - Forms galls on edges of lobes of leaf, causing them to curl downward and become thickened.

Distribution-Europe.

References - Kaltenbach, J. H. Pflanzenfeinde, p. 213. 1872.

Connold, E. T. British vegetable galls, p. 138. 1902.

pilosus Can., Tetranychus.

Fam. Tetranychidae

Hosts - Crataegus, Malus, Pyrus, Prunus.

Injury - Feeds on leaves, causing them to turn brownis`.

Distribution - Europe, North America.

Reference - Caesar, L. Can. ent. 47:57. 1915.

pyracanthae Link., Eriophyes.................................... Eriophyidae

Hosts - Crataegus punctata, C. pyracantha.

Injury - Makes galls on leaves. Galls almost flat, reddish, covered with many fine, capitate hairs.

Distribution - North America.

Reference - Chadwick, G. H. New York State Mus. Bul. 124:131. 1908.

pyri Pagst., Eriophyes (Pear leaf blister mite)................... Fam. Eriophyidae Hosts - Pyrus, Malus, Crataegus, Cydonia, Sorbus, Amelanchier.

Injury - Makes yellowish or reddish blisters on leaves.

? The insects are grouped according to order, and arranged alphabetically by species within the order. 
Distribution - Europe, North America, Australia.

References - Slingerland, M. V., and Crosby, C. R. Manual of fruit insects, p. 227. 1914.

Wilson, H. F. Oregon Agr. Exp. Sta. Bien. crop pest and hort. rept. 2:123. 1915 .

telarius Linn., Tetranychus (Red spider)

(See page 1051.)

Eriophyes sp. (Hawthorn serpentine gall of Jarvis) . . . . . . . . . . Fam. Eriophyidae

Host - Crataegus.

Injury - Makes long, irregular, wavy galls on upper surface of leaves.

Distribution - North America.

Reference - Jarvis, T. D. Ent. Soc. Ont. Rept. 37:60. 1906.

(Figs. 102 and 103, pages 1052 and 1053.)

\section{ORTHOPTERA}

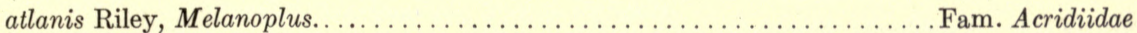
(See page 1054.)

bivitattus Say, Melanoplus. Fam. Acridiidae

(See page 1054.)

femur-rubrum De Geer, Melanoplus

Fam. Acridiidae

(See page 1054.)

niveus De Geer, Oecanthus (Snowy tree cricket)

Hosts - Malus, Rubus, Salix, Crataegus, Ulmus, Quercus, and other species.

Injury - Female slits bark to deposit eggs. Slits give entrance to cankers and cause scars on branches.

Distribution - North America, Cuba.

Reference-Parrott, P. J., and Fulton, B. B. New York (Geneva) Agr. Exp. Sta. Bul. 388. 1914.

\section{ODONATA}

viridis v. d. Lind., Lestes. . . . . . . . .........................Fam. Agrionidae

Hosts - Crataegus oxyacantha and other species.

Injury - Oviposition punctures in twigs cause galls to form.

Distribution - Europe.

References - Pierre, P. F. M. Rev. sci. Bourbonnais 15:181. 1902.

Houard, C. Les zoocecides des plantes d'Europe, 1:514. 1908.

\section{HEMIPTERA}

aceris Sign., Phenacoccus................................... Fam. Coccidae

Hosts - Crataegus oxyacantha and many other woody plants.

Injury - Sucks sap from tender bark of young shoots and calloused wounds. Sometimes seriously injures grape.

Distribution - Europe.

References - Lindinger, L. Die Schildläuse, p. 214. 1912.

Carpenter, G. H. Roy. Dublin Soc. Econ. proc. 2:142-160. 1914.

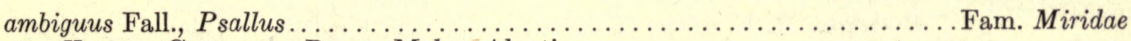

Hosts - Crataegus, Pyrus, Malus, Alnetis.

Distribution - Europe.

References - Reuter, O. M. Hemiptera gymnocerata Europae 1:105. 1878. Leonardi, G. Gli insetti 4:98. 1901. 


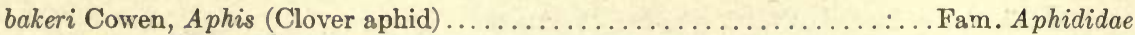
Hosts - Malus, Crataegus, clover.

Injury - Sucks juice from opening buds of fruit trees.

Distribution - North America.

References - Quaintance, A. L., and Baker, A. C. U. S. Agr. Dept. Farmers' bul. 804:15. 1917.

Patch, E. M. Maine Agr. Exp. Sta. Bul. 270:49. 1918.

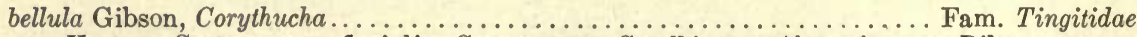

Hosts - Crataegus neofluvialis, C. punctata, C. albicans, Alnus incana, Ribes oxyacanthoides.

Injury - Bot's young and adult bugs suck juice from leaves, causing them to turn brown and drop off.

Distribution - Northeastern United States, Canada.

References - Gibson, E. H. Amer. Ent. Soc. Trans. 44:93. 1918.

Wellhouse, W: H. Journ. econ. ent. 12:441. 1919.

(Plates LXXII and LXXIII, pages 1057 and 1059.)

betulae Bär., Epidiaspis (European pear scale) .....................Fam. Coccidae

Synonyms - Epidiaspis leperi Sign., E. piricola De Geer, Diaspis piri Colv.

Hosts - Pyrus, Malus, Prunus, Crataegus, and other species.

Injury - Very injurious to young twigs and branches of apple and pear in southern Europe, where the bark becomes incrusted.

Distribution - South and middle Europe, United States.

References - Lindinger, L. Die Schildläuse, p. 213. 1912.

Essig, E. O. Injurious and beneficial insects of California, p. 172.1915.

bituberculatum Targ., Lecanium.............................. Fam. Coccidae

Hosts - Crataegus oxyacantha, Malus, Pyrus.

Injury - Sucks sap from bark, sometimes killing young trees.

Distribution - Europe, North America.

References - Sorauer, P. Handbuch der Pflanzenkrankheiten 3:695. 1913.

Dietz, H. F., and Morrison, H. Indiana State Ent. Ann. rept. 8:254. 1916.

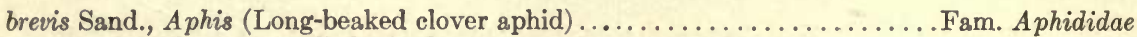

Hosts - Crataegus, Cydonia, Pyrus, clovers, sweet pea.

Injury - Curls and turns purplish the terminal leaves of Crataegus shoots during June.

Distribution - United States.

Reference - Patch, E. M. Journ. agr. res. 3:431. 1915.

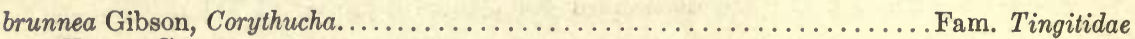

Host - Crataegus.

Injury - Sucks juice from foliage.

Distribution - Suthern United States.

Reference - Gibson, E. H. Amer. Ent. Soc. Trans. 44:93. 1918.

bubalis Fabr., Ceresa (Buffalo tree hopper)........................ Membracidae

Hosts - Malus, Crataegus, and other species.

Injury - Adult makes incisions, in branches for oviposition. Incisions are slow to heal and allow entrance of borers and fungi.

Distribution - North America.

References - Packard, A. S. Fifth rept. U. S. Ent. Comm., p. 535. 1890.

Hodgkiss, H. E. New York (Geneva) Agr. Exp. Sta. Tech. bul: 17:92. 1910.

clitellarius Say, Thamnotettix

(See page 1061.) 


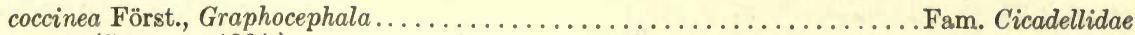
(See page 1061.)

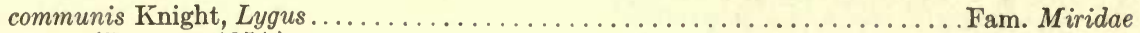
(See page 1054.)

corni Bouché, Lecanium (European fruit lecanium). Fam. Coccidae Hosts - Crataegus, Malus, Prunus, and other species.

Injury - May suck so much sap from branches as to kill them, but commoner injury is due to growth of sooty fungus over sticky secretion which the insects drop on foliage, fruit, and branches.

Distribution - Europe, North Amęrica.

References - Sorauer, P. Handbuch der Pflanzenkrankheiten 3:695. 1913.

Slingerland, M. V., and Crosby, C. R. Manual of fruit insects, p. 261. 1914.

corrugatans Sir., Pemphigus (Woolly thorn aphis) Fam. Aphididae Hosts - Crataegus, Amelanchier, Pyrus, Cydonia.

Injury - Distorts leaves into a rolled curl.

Distribution - North America.

References - Patch, E. M. Maine Agr. Exp. Sta. Bul. 233. 1914.

Quaintance, A. L., and Baker, A. C. U. S. Agr. Dept. Farmers' bul. 804: 19. 1917.

coryli Linn., Lecanium

Synonyms - Eulecanium pyri Schr., Lecanium capreae Linn.

Hosts - Malus, Crataegus, Pyrus, and other species.

Injury - Sucks sap from bark, not commonly injurious.

Distribution - Europe, North America.

References - Theobald, F. V. Insect pests of fruits, p. 175. 1909.

Lindinger, L. Die Schildläuse, p. 216.1912.

costalis Flor., Psylla.

Fam. Psyllidae

Hosts - Malus, Crataegus, Sorbus, Quercus.

Distribution - Europe.

Refere ce-Harrison, J. W. H. Naturalist (London), no. 707, p. 400. 1915.

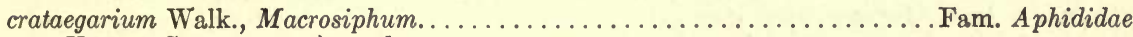
Host - Crataegus oxyacantha.

Distribution - Enlgand.

References - Walker, F. Ann. mag. nat. hist. 6:46. 1850.

Theobald, F. V. Journ. econ. biol. 8:142. 1913.

crataegi Kalt., Aphis

Synonyms - Aphis pyri Boyer, A. crataegi Koch, A. ranunculi Kalt.

Hosts - Crataegus oxyacantha, $C$. azarolus, Malus, Ranunculus.

Injury - Curls, discolors, and blisters leaves on terminal shoots.

Distribution - Europe.

References - Dobrovliansky, V. V. Biology of aphids of tree and bush fruits (Kiev). 1913.

Van der Goot, P. Holländischen Blattläuse, p. 174. 1915.

Theobald, F. V. Entomologist 48:259. 1915.

crataegi Fitch, Glossonotus (Hawthorn tree hopper)

Fam. Membracidae

Hosts - Crataegus, Malus, Cydonia.

Distribution - North America.

References - Fitch, A. Third annual report on noxious insects of New York, p. 334. 1856.

Funkhouser, W. D. Cornell Univ. Agr. Exp. Sta. Memoir 11:248. 1917. 
crataegi VanD., Idiocerus...................................... Cicadellidae Host - Crataegus.

Injury - Adults and young suck juice from foliage.

Distribution - North America.

Reference - Van Duzee, E. P. Can. ent. 22:110. 1890.

crataegi Monell, Macrosiphum.

Hosts - Crataegus punctatx, C. coccinea, C. oxyacantha.

Injury - Sucks juice from lower side of leaves and from tender twigs. Leaves curl downward and in severe infestations trees may be defoliated.

Distribution - North America.

Reference - Patch, E. M. Maine Agr. Exp. Sta. Bul. 233:255. 1914.

(Fig. 108, page 1063.)

crataegi Tullgr., Prociphilus. Fam. Aphididae

Hosts - Crataegus oxyacantha, Malus.

Injury - Curls and discolors leaves and sometimes injures blossoms.

Distribution - Europe.

Reference - Van der Goot, P. Holländischen Blattläuse, p. 450. 1915.

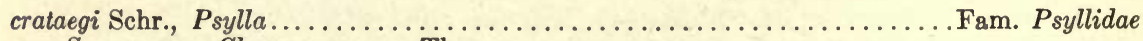
Synonym - Chermes quercus Thoms.

Hosts - Cratzegus oxyacantha, Quercus sp.

Injury - Causes small red blisters to form on upper side of leaves.

Distribution - Europe.

Reference - Aulmann, G. Psyllidarum catalogus, p. 13. 1913.

crataegi Dgl., Typhlocyba

Hosts - Crataegus oxyacantha, apple (?).

Injury - Nymphs and adults suck juice from foliage, but commonly they are not numerous enough to cause much injury.

Distribution - Europe.

References - Douglas, J. W. Ent. mo. mag. 12:203. 1876.

Melichar, L. Cicadinen von Mittel-Europe, p. 348. 1896.

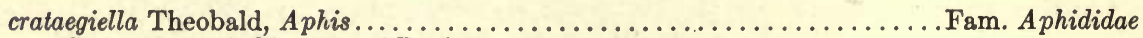
Synonym-Aphis crataegi Buck.

Host - Crataegus oxyacantha.

Injury - Curls and discolors leaves of terminal shoots, which turn reddish brown.

Distribution - Europe.

References - Buckton, G. B. Monograph of British aphides, 2:35. 1879.

Theobald, F. V. List of Aphididae of Hastings District, p. 9. 1912.

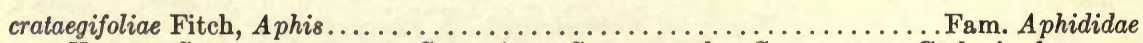
Hosts - Crataegus punctata, C. coccinea, C. oxyacantha, C. tomentosa, Cydonia, legumes. Injury - Curls and discolors leaves and young shoots, turning them purplish.

Distribution - North America.

Reference-Quaintance, A. L., and Baker, A. C. U. S. Agr. Dept. Farmers' bul. 804:18. 1917.

crataegus-coccinea Rafin., Aphis. Fam. Aphididae

Host - Crataegus coccinea.

Distribution - North America.

References - Rafinesque, C. S. Amer. mo. mag. and crit. rev. 3:16. 1818. Patch, E. M. Maine Agr. Exp. Sta. Bul. 270:48. 1918.

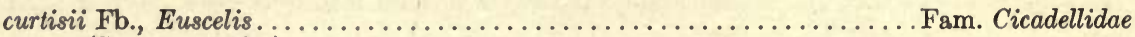
(See page 1161.) 
cydoniae Fitch, Corythucha.

Synonyms - Corythucha arcuata Comst., C. crataegi O. \& D.

Hosts - Crataegus, Cydonia.

Injury - Nymphs and adults suck juice from leaves, causing them to turn brown.

Distribution - North America.

References - Fitch, A. Country gent. 17:25. 1861.

Comstock, J. H. U. S. Ent. Rept. 1879:221. 1879.

Gibson, E. H. Amer. Ent. Soc. Trans. 44:87. 1918.

dearnessi King, Phenacoccus.................................Fam. Coccidae

Synonym - Phenacoccus betheli Ckll.

Hosts - Crataegus, Amelanchier.

Distribution - Canada, United States.

Reference - Ferris, G. F. Contribution to knowledge of Coccidae of southwestern United States, p. 68. 1919.

dislocatus Say, Horcias .

(See page 1054.)

dumetorum Schiff., Physatocheila...........................Fam. Tingitidae

Hosts - Crataegus oxyacantha, Pyrus communis, Prunus padus, P. spinosa.

Distribution - Europe, Egypt.

References - Kaltenbach, J. H. Pflanzenfeinde, p. 213. 1872.

Saunders, E. Hemiptera of British Islands, p. 135. 1892.

edentula Buck., Aphis.

Host - Crataegus oxyacantha.

Distribution - Europe.

Reference - Buckton, G. B. Monograph of British aphides, 2:39. 1879.

fitchi VanD., Idiocerus (Black apple leaf hopper)................... Fam. Cicadellidae Synonym - Idiocerus maculipennis Fitch.

Hosts - Crataegus, Malus, Pyrus.

Injury - Adults and young suck juice from foliage. Not commonly injurious.

Distribution - North America.

References - Van Duzee, E. P. Catalog of Hemiptera, p. 580. 1916. Brittain, W. H., and Saunders, L. G. Can. ent. 49:149. 1917.

flavicephala Goding, Ophiderma ...................................... Membracidae (See page 1063.)

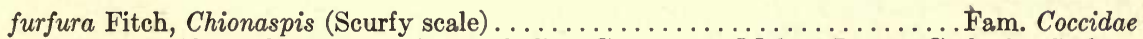
Hosts - About 25 tree species, including Crataegus, Malus, Pyrus, Cydonia, Sorbus.

Injury - Occasionally incrusts bark of trees and greatly weakens or kills them.

Distribution - North America.

References - Slingerland, M. V., and Crosby, C. R. Manual of fruit insects, p. 176. 1914.

Essig, E. O. Injurious and beneficial insects of California, p. 158. 1915.

hederae Vall., Aspidiotus...................................Fam. Coccidae

Synonym - Aspidiotus nerii Bouché.

Hosts - Many woody and herbaceous plants, including Crataegus azarolus.

Distribution - Europe, Asia, North Africa (on Crataegus in Algeria), North America.

References - Lindinger, L. Die Schildläuse, p. 213. 1912.

Sorauer, P. Handbuch der Pflanzenkrankheiten 3:689. 1913.

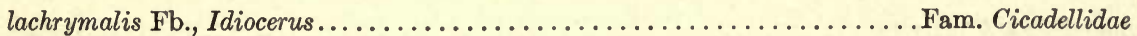

(See page 1061.) 
lanigera Hausm., Eriosoma (Woolly aphis)............................ Aphididae Synonyms - Eriosoma crataegi Oest., Schizoneura americana Riley.

Hosts - Cratregus, Malus, Ulmus americana.

Injury - Sucks sap from tender shoots, branches, and roots, often stunting growth.

Distribution - North America, Europe, Africa, Australia, South America.

References - Theobald, F. V. Insect pests of fruits, p. 141. 1909.

Baker, A. C. U. S. Agr. Dept. Rept. 101. 1915.

(Fig. 109, page 1064.)

Becker, G. G. Journ. econ. ent. 11:245. 1918.

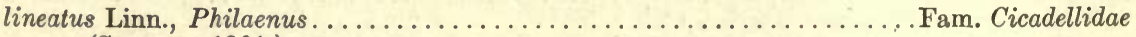
(See page 1061.)

maii LeB., Empoasca (Apple leaf hopper)........................... Cicadellidae (See page 1061.)

mali Schmid., Psylla. Fam. Psyllidive Synonym - Psylla crataegicola Först.

Hosts - Crataegus oxyacantha, Malus, Pyrus, Sorbus, Quercus, Ulmus, Corylus.

Injury - Nymphs suck juice from foliage and blossoms, and prevent setting of fruit.

Distribution - Europe, Asia, Nova Scotia.

References - Kaltenbach, J. H. Pflanzenfeinde, p. 213. 1872.

Theobald, F. V. Insect pests of fruits, p. 153.1909.

Brittain, W. H. Journ. econ. ent. 15:96. 1922.

malinus Reuter, Heterocordylus (Dark apple redbug)...................... Miridae

Hosts - Crataegus, Malus.

Injury - Nymphs and adults puncture leaves and fruit to suck juice. Cause dimples

in fruit, which deform it.

Distribution - Northeastern United States, Canada.

References - Slingerland, M. V., and Crosby, C. R. Manual of fruit insects, p. 28. 1914.

Cushman, R. A. Ent. Soc. Washington. Proc. 18:196. 1916.

marutae Oest., Aphis .

Hosts - Cratregus, Anthemis cotula.

Distribution - North America.

References - Oestlund, O. W. Aphididae of Minnesota, p. 40. 1886.

Hunter, 1901, p. 101. (Cited by Patch, E. M. Maine Agr. Exp. Sta. Bul. 270:49. 1918.)

melanoneura Först., Psylla

Synonym - Psylla crataegi Först.

Hosts - Crataegus oxyacantha, Quercus, and other species.

Distribution - Europe, Asia.

References - Aulmann, G. Psyllidarum catalogus, p. 20. 1913.

Harrison, J. W. H. Naturalist (London), no. 707, p. 400. 1915.

mendax Reuter, Lygidea (Bright apple redbug) ................... Fam. Miridae

Hosts - Malus, Crataegus.

Injury - Nymphs and adults puncture leaves and fruit to suck juice, and cause dimples in fruit.

Distribution - Northeastern United States, Canada.

References - Slingerland, M. V., and Crosby, C. R. Manual of fruit insects, p. 28. 1914.

Cushman, R. A. Ent. Soc. Washington. Proc. 18:196. 1916.

mespili v.d.G., Ovatus.............................Fam. Aphididae

Hosts - Crataegus oxyacantha, Mespilus germanica. 
Injury - Sucks sap from tender shoots and leaves.

Distribution - Europe.

Reference - Van der Goot, P. Holländischen Blattläuse, p. 136. 1915.

nigrofasciatum Perg., Lecanium (Terrapin scale) . . . . . . . . . . . . . . . . Fam. Coccidae

Hosts - Prunus, Acer, Malus, Crataegus, Tilia, Platanus, and other species.

Injury - Sucks sap from bark and secretes much sticky liquid, which covers surface of branches, foliage, and fruit and on which a sooty fungus grows, thus rendering fruit unsalable.

Distribution - North America.

References - Felt, E.P. New York State Mus. Memoir 81:201. 1905.

Slingerland, M. V., and Crosby, C. R. Manual of fruit insects, p. 293. 1914.

obliqua Say, Erythroneura .

.Fam. Cicadellidae

(See page 1061.)

oleae Colvee, Parlatoria. Fam. Coccidae

Hosts - Many woody plants, including Crataegus germanica.

Injury - May incrust the bark, and sometimes the leaves and the fruit, of trees of the genera Citrus, Pyrus, and Olea especially.

Distribution - Mediterranean region.

References - Lindinger, L. Die Schildläuse, p. 213. 1912.

Sorauer, P. Handbuch der Pflanzenkrankheiten 3:694. 1913.

olivaceus Fabr., Deraeocoris................................... Fam. Miridae

Synonym-Capsus medius Kirschb.

Hosts - Malus, Crataegus, Prunus, Corylus.

Injury - Sucks juice from foliage.

Distribution - Europe.

References - Kaltenbach, J. H. Pfanzenfeinde, p. 213. 1872.

Reuter, O. M. Hemiptera gymnocerata Europae 5:30. 1896.

ornatus VanD., Orthotylus.......................................... Midae (See page 1055.)

ostreiformis Curt., Aspidiotus (European fruit-tree scale). . . Fam. Coccidae

Synonym - Aspidiotus oxyacanthae Sign.

Hosts - Malus, Prunus, Pyrus, Crataegus, and many other woody plants.

Injury - May completely incrust the bark and kill the tree.

Distribution - Europe, Asia Minor, North America.

References - Theobald, F. V. Insect pests of fruits, p. 386. 1909. Lindinger, I. Die Schildläuse, p. 213. 1912.

ostryae Knight, Lygus. .

Fam. Miridae

(See page 1055.)

oxyacanthae Schr., Myzus . Fam. Aphididae

Synonym - Aphis oxyacanthae Koch.

Hosts - Crataegus oxyacantha, Pyrus, Malus, Prunus.

Injury - Sucks juice from leaves, causing yellow or red swellings on them and making them curl.

Distribution - Europe.

References - Koch, C. L. Pflanzenläuse, p. 55. 1857.

Ross, H. Die Pflanzengallen Mittel- und Nordeuropas, p. 132. 1911.

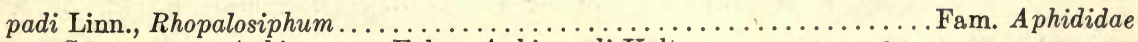

Synonyms - Aphis avenae Fabr., A phis padi Kalt.

Hosts - Prunus padus, Crataegus, Malus, Pyrus, grasses. 
Injury - Sucks juice from opening buds of fruit trees in early spring.

Distribution - Europe, North America.

References - Leonardi, G. Gli insetti 4:228. 1901.

Baker, A. C. Journ. agr. res. 18:311. 1919.

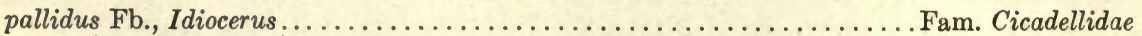

(See page 1062.)

pellucida Uhl., Diaphnidia....................................... Miridae

(See page 1055.)

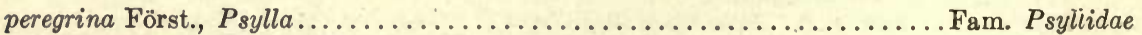

Synonym - Psylla crataegicola Flor.

Hosts - Crataegus oxyacantha, Carpinus betulus.

Injury - Sucks juice from young shoots and foliage.

Distribution - Europe, Asia.

Reference - Aulmann, G. Psyllidarum catalogus, p. 22.1913.

perniciosus Comst., Aspidiotus (San José scale).................. Fam. Coccidae

Hosts - Many woody plants, including Crataegus and other Malaceae.

Injury - May incrust bark and kill trees in favorable weather.

Distribution - Asia, North America, South America, Australia, Hawaii.

References - Sorauer, P. Handbuch der Pflanzenkrankheiten 3:690. 1913.

Glenn, P. A. State Ent. Illinois. Rept. 28:87. 1915.

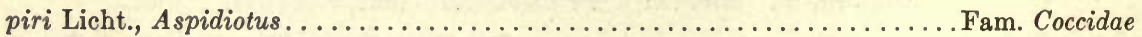

Hosts - Pyrus, Malus, Crataegus, Fraxinus, Prunus.

Injury - May incrust branches and thus weaken or kill them.

Distribution - Europe, Asia Minor.

References - Lindinger, L. Die Schildläuse, p. 214. 1912.

Sorauer, P. Handbuch der Pflanzenkrankheiten 3:690. 1913.

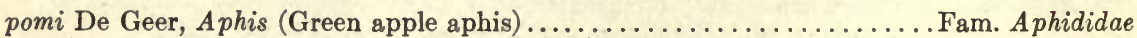

Synonyms - Aphis mali Fabr., A. oxyacanthae Schr.

Hosts - Malus, Crataegus, grasses.

Injury - Sucks sap, causing leaves to curl, but no discoloration appears.

Distribution - Europe, North America.

References - Kaltenbach, J. H. Pflanzenfeinde, p. 202.1872.

Matheson, R. Cornell Univ. Agr. Exp. Sta. Memoir 24:686. 1919.

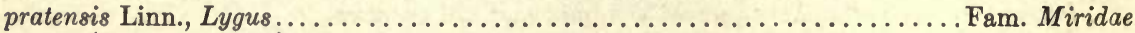

(See page 1055.)

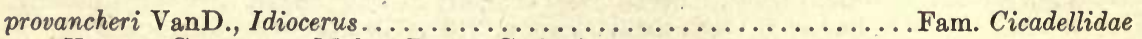

Hosts - Crataegus, Malus, Pyrus, Cydonia.

Injury - Nymphs and adults suck juice from foliage.

Distribution - North America.

References - Leonard, M. D. Journ. econ. ent. 8:415. 1915.

Van Duzee, E. P. Catalog of Hemiptera, p. 580. 1916.

pruinosum Coq., Lecanium (Frosted scale)............................ Coccidae

Hosts - Many woody plants, including Crataegus.

Injury - Principal injury from smutty fungus growing on honeydew secreted by insects on fruit and foliage.

Distribution - North America.

References - Sanders, J. G. Journ. econ. ent. 2:442. 1909.

Essig, E. O. Injurious and beneficial insects of California, p. 149. 1915.

prunifoliae Fitch, Rhopalosiphum (Apple bud aphis)................Fam. Aphididae

Synonyms - Aphis avenae (of American authors), Aphis fitchii Sand. 
Hosts - Malus, Pyrus, Crataegus, Prunus, many grasses.

Injury - Sucks juice from opening buds of trees in spring.

Distribution - North America.

References - Quaintance, A. L. U. S. Ent. Bur. Circ. 81. 1907. Baker, A. C. Journ. agr. res. 18:311. 1919.

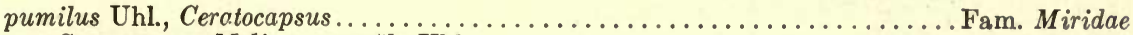

Synonym - Melinna pumila Uhl.

Hosts - Crataegus, Salix.

Injury - Adult sucks sap from foliage.

Distribution - Eastern United States.

Reference - Uhler, P. R. Ent. Amer. 3:69. 1887.

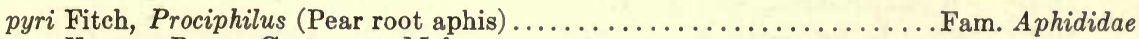
Hosts - Pyrus, Crataegus, Malus.

Injury - Sucks sap from roots.

Distribution - Eastern North America.

References - Quaintance, A. L., and Baker, A. C. U. S. Agr. Dept. Farmers' bul. 804: 19. 1917.

Wilson, H. F., and Vickery, R. A. Wisconsin Acad. Sci., Arts, and Letters. Trans. 19:140. 1918.

querci Fitch, Empoa

(See page 1062.)

rosae Linn., Empoa (Rose leaf hopper)......................... Cicadellidae Hosts - Rosa, Malus, Pyrus, Prunus, Crataegus, Cydonia, and other species.

Injury - Nymphs and adults suck juice from lower leaves of trees, causing yellowing of foliage and in some cases defoliation.

Distribution - Europe, North America.

Reference-Ackerman, A. J. U. S. Agr. Dept. Bul. 805:20. 1919.

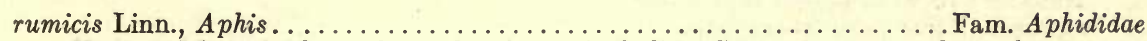
Hosts - Many herbs and woody plants, including Crataegus oxyacantha and pear.

Injury - Sucks juice from foliage in spring and fall.

Distribution - Europe, North America.

References - Börner. Nat. Ver. Bremen. Abhandl. 23:152. 1914.

Van der Goot, P. Holländischen Blattläuse, p. 220. 1915.

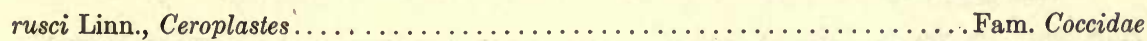

Hosts - Many plants, including Crataegus.

Injury - Sucks juice from bark, leaves, and fruit.

Distribution - Mediterraneán region.

References - Lindinger, L. Die Schildläuse, p. 214. 1912.

Sorauer, P. Handbuch der Pflanzenkrankheiten 3:695. 1913.

saliceti Först., Psylla.

Fam. Psyllidae

Hosts - Salix, Crataegus oxyacantha.

Injury - Sucks juice from foliage.

Distribution - Europe, Asia, Japan.

Reference - Aulmann, G. Psyllidarum catalogus, p. 26. 1913.

seminudus Say, Eutettix. Fam. Cicadellidae (See page 1062.)

sorbi Kalt., Aphis (Rosy apple aphis).

Synonym - Apliis malifoliae Fitch.

Hosts - Malus, Pyrus, Crataegus, Sorbus, Plantago.

Injury - Cur.s leaves and deforms fruit. 
Distribution - Europe, North America.

References - Van der Goot, P. Holländischen Blattläuse, p. 177. 1915.

Matheson, R. Cornell Univ. Agr. Exp. Sta. Memoir 24:718. 1919.

suturalis $\mathrm{Fb} .$, Idiocerus

(See page 1062.)

taurina Fitch, Ceresa...

(See page 1063.)

ulmi Linn., Lepidosaphes (Oyster-shell scale).

Synonym - Mytilaspis pomorum Bouché.

Hosts - Many woody plants, including Crataegus.

Injury - Sucks juice from bark and foliage.

Distribution - Europe, Asia, Africa, Australia, North America, South America, Hawaii.

References - Theobald, F. V. Insect pests of fruits, p. 170. 1909.

Sorauer, P. Handbuch der Pflanzenkrankheiten 3:692. 1913.

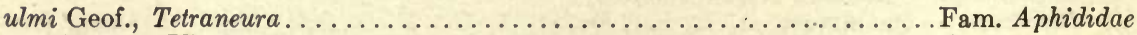

Hosts - Ulmus, Crataegus oxyacantha, many grasses.

Injury - Sucks juice from leaves, causing galls to form on upper surface.

Distribution - Europe.

References - Van der Goot, P. Holländischen Blattläuse, p. 484. 1915.

Patch, E. M. Maine Agr. Exp. Sta. Bul. 270:49. 1918.

univittatus Knight, Lygus.

Fam. Miridae

Host - Crataegus.

Injury - Adults suck juice and puncture fruit and tender foliage.

Distribution - Northeastern United States.

Reference - Knight, H. H. Brooklyn Ent. Soc. Bul. 14:21. 1919.

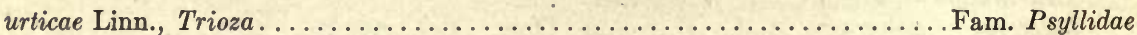

Hosts - Urtica, Crataegus oxyacantha.

Injury - Sucks juice from foliage.

Distribution - Europe, Asia.

References - Aulmann, G. Psyllidarum catalogus, p. 56. 1913.

Harrison, J. W. H. Naturalist (London), no. 707, p. 400. 1915.

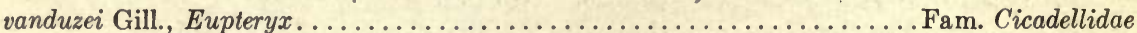

(See page 1062.)

vitis Linn., Pulvinaria (Cottony scale) ...................... Fam. Coccidae Synonyms - Pulvinaria betulae Linn., $P$. innumerabilis Rath., $P$. oxyacanthae Linn.

Hosts - Many woody plants, including Crataegus.

Injury - Sucks sap from bark and tender shoots.

Distribution - Europe, America, Africa, Asia Minor.

Reference - Lindinger, L. Die Schildläuse, p. 215. 1912.

vulgaris $\mathbf{F b}$., Lamenia. .

Fam. Cicadellidae

(See page 1063.)

\section{THYSANOPTERA}

tritici Fitch, Euthrips.

(See page 1066.)

\section{COLEOPTERA}

aeneovirens Marsh, Rhynchites, var. punctatus Oliv. Fam. Curculionidae

Host - Crataegus oxyacantha.

Distribution - Europe.

Reference - Bargagli, P. Rincofori Europei, p. 181. 1893. 
aenescens Lec., Magdalis (Bronze apple weevil) Fam. Curculionidae

Hosts - Malus, Crataegus, Prunus.

Injury - Larva tunnels under bark, sometimes killing tree. Adults feed on leaves.

Distribution - Northwestern United States, Canada.

References - Chittenden, F. H. U. S. Ent. Bur. Bul. 22:37. 1900.

Slingerland, M. V., and Crosky, C. R. Manual of fruit insects, p. 199. 1914.

ae quatus Linn., Rhynchites................................. Curculionidae

Hosts - Crataegus, Malus, Prunus, Sorbus.

Injury - Beetles puncture fruit buds and leaves in feeding.

Distribution - Europe.

References - Kaltenbach; J. H. Pflanzenfeinde, p. 181.1872.

Bargagli, P. Rincofori Europei, p. 181. 1883.

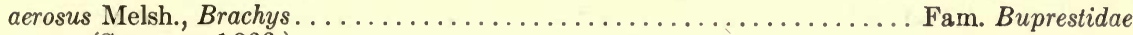
(See page 1066.)

albida Lec., Syneta....................................Fam. Chrysomelidae

Hosts - Malus, Pyrus, Cydonia, Crataegus, Prunus, Corylus, and other species.

Injury - Beetles feed on flowers and foliage, sometimes defoliating young trees.

Distribution - Western United States.

References - Wilson, H. F., and Moznette, G. F. Oregon Agr. Exp. Sta. Bien. crop pest and hort. rept. 2:96. 1915.

alpina Linn., Rosalia............................. Fam. Cerambycidae

Hosts - Crataegus oxyacantha, Fagus sp.

Injury - Larva tunnels under bark, girdling branches, and then enters solid wood.

Distribution - Europe.

References - Kaltenbach, J. H. Pflanzenfeinde, p. 207. 1872.

Holeczek, A. Ent. Nachr. 13:308. 1887.

auratus Scop., Rhynchites .

Fam. Curculionidae

Synonym - Rhynchites bacchus Oliv.

Hosts - Crataegus oxyacantha, Prunus spinosa, Malus.

Injury - Beetles cut off petioles of leaves, and larvae feed in fruit.

Distribution - Europe, Asia.

References - Kaltenbach, J. H. Pflanzenfeinde, p. 153. 1872.

Bargagli, P. Rincofori Europei, p. 183. 1883.

bacchus Linn., Rhynchites (Purple apple weevil).

Fam. Curculionidae

Hosts - Malus, Crataegus.

Injury - Larvae feed in fruit, much like codling moth.

Distribution - Europe, Asia.

References - Kaltenbach, J. H. Pfianzenfeinde, p. 207. 1872.

Theobald, F. V. Insect pests of fruits, p. 121. 1909.

barbicornis Lat., Magdalis (Apple stem piercer).................Fam. Curculionidae

Hosts - Malus, Cydonia, Crataegus.

Injury - Larvae tunnel under bark, causing discolored, sunken areas.

Distribution - Europe, United States (New York and Massachusetts), imported recently.

References - Henschel, G. A. O. Die schädlichen forst- und obstbaum Insekten, p. 94 . 1895.

Blatchley, W. S., and Leng, C. W. Rhynchophora of north eastern America, p. 257.1916.

Pierce, W. D. Manual of dangerous insects, p. 132.1917.

bipunctatus Iinn., Cryptocephalus............................. Chrysomelidae Hosts - Crataegus, Corylus, Salix, Betula. 
Injury - Beetles eat holes in foliage.

Distribution - Europe.

References - Redtenbacher, L. Fauna Austriaca. Die Käfer, p. 901. 1858. Kaltenbach, J. H. Pflanzenfeinde, p. 207. 1872.

borealis Shev., Dibolia. Fam. Chrysomelidae (See page 1067.)

calva Lec., Limnobaris.

Host - Crataegus.

Distribution - Eastern United States.

Reference-Hamilton, J. Amer. Ent. Soc. Trans. 22:377. 1895.

candida Fabr., Saperda (Round-headed apple-tree borer)............Fam. Cerambycidae Synonym - Saperda bivittata Say.

Hosts - Cydonia, Malus, Sorbus, Amelanchier, Pyrus, Crataegus.

Injury - Larvae tunnel under bark of trunk and into sapwood. Not commonly injurious to Crataegus.

Distribution - North America.

References - Glover, T. Manuscript notes from my journal, p. 87. 1877.

Felt, E. P., and Joutel, L. H. New York State Mus. Bul. 74:28. 1904. Becker, G. G. Arkansas Agr. Exp. Sta. Bul. 146:5. 1918.

carinata Germ., Haltica

(See page 1067.)

caudatus Rossi, Otiorrhynchus

Host - Crataegus oxyacantha.

Distribution - Europe.

References - Marseul, M. S. A. Monographie des Otiorhynchides, p. 127. 1872.

Bargagli, P. Rincofori Europei, p. 63. 1883.

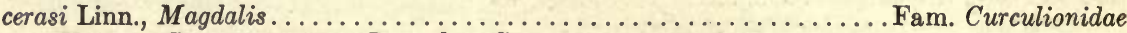

Hosts - Prunus cerasus, P. padus, Crataegus oxyacantha.

Injury - Larva burrows under bark.

Distribution - Europe.

References - Redtenbacher, L. Fauna Austriaca. Die Käfer, p. 758. 1858.

Bargagli, P. Rincofori Europei, p. 195. 1883.

Pierce, W. D. Manual of dangerous insects, p. 132.1917.

coeruleocephalus Schel., Rhynchites........................... Curculionidae

Hosts - Crataegus oxyacantha, Betula, Quercus.

Distribution - Europe.

References - Kaltenbach, J. H. Pflanzenfeinde, p. 589. 1872.

Bargagli, P. Rincofori Europei, p. 187. 1883.

colaspidoides Gyll., Diphucephala.

Hosts - Prunus, Crataegus oxyacantha.

Injury - Beetles appear in swarms, like locusts, and defoliate trees and shrubs.

Distribution - Australia.

References - Insect life 3:425. 1890.

French, C. Destructive insects of Victoria, 2:27. 1893.

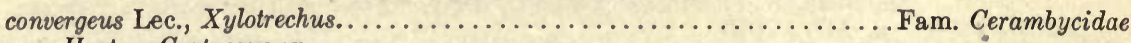

Host - Crataegus sp.

Injury - Larva tunnels in branches.

Distribution - North America.

Reference - LeConte, J. L. Amer. Ent. Soc. Trans. 8:xxiv. 1880. 
crataegi Walsh, Conotrachelus (Quince curculio).

Hosts - Crataegus spp., Cydonia.

Injury - Larvae feed within fruit, partially destroying it.

Distribution - Eastern United States.

References - Riley, C. V. Third Missouri rept., p. 35. 1871.

Slingerland, M. V. Cornell Univ. Agr. Exp. Sta. Bul. 148. 1898.

crataegi Germ., Otiorrhynchus ................................. Curculionidae

Host - Crataegus oxyacantha.

Distribution - Europe.

References - Marseul, M. S. A. Monographie des Otiorhynchides, p. 287. 1872.

Bargagli, P. Rincof ori Europei, p. 63. 1883.

crataegi Walsh, Pseudanthonomus (Apple weevil).................Fam. Curculionidae

Hosts - Crataegus, Malus, Kalmia latifolia.

Injury - Larvae burrow in fruit, beetles puncture fruit and foliage.

Distribution - Eastern United States, Canada.

References - Brooks, F. E. West Virginia Agr. Exp. Sta. Bul. 126.1910.

Blatchley, W. S., and Leng, C. W. Rhynchophora of north eastern America, p. 318. 1916.

cretata Newm., Saperda (Spotted apple-tree borer).

Fam. Cerambycidae

Hosts - Malus, Crataegus, Amelanchier.

Injury - Larvae kill branches by girdling and tunneling in sapwood.

Distribution - Eastern North America.

References - Osborn, H. Iowa State Hort. Soc. Trans. 15:11. 1880.

Hamilton, J. Amer. Ent. Soc. Trans. 22:369. 1895.

Felt, E. P., and Joutel, L. H. New York State Mus. Bul. 74:50. 1904.

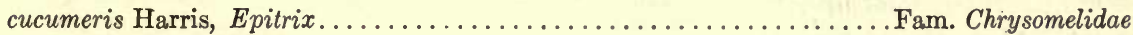
(See page 1067.)

decipiens Lec., Anthonomus................................ Curculionidae

Hosts - Crataegus, cotton (?); beetles in abundance beaten from Crataegus sp. by Dr. Hamilton.

Distribution - North America.

Reference - Blatchley, W. S., and Leng, C. W. Rhynchophora of north eastern America, p. 316. 1916.

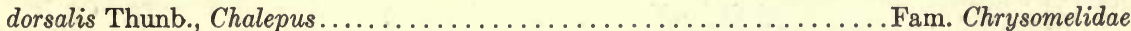

Hosts - Robinia, Malus, Quercus, Crataegus, Rubus, and other species.

Injury - Beetles eat foliage.

Distribution - North America.

Reference - Houser, J. S. Ohio Agr. Exp. Sta. Bul. 332:231. 1918.

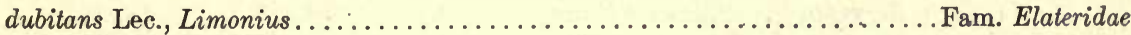
(See page 1066.)

elongata Fabr., Dichelonycha. Fam. Scarabaeidae (See page 1066.)

fayi Bland, Saperda (Thorn limb borer)

Hosts - Crataegus crus-galli, C. tomentosa.

Injury - Larvae burrow in smaller branches, killing them and producing gall-like swellings which weaken the branches so that they break in winds.

Distribution - Eastern North America.

Reference-Felt, E. P., and Joutel, L. H. New York State Mus. Bul. 74:62. 1904. femorata Fabr., Chrysobothris (Flat-headed apple-tree borer)...........Fam. Buprestidae Hosts - Many trees, including Crataegus, but especially Quercus, Malus, Prunus. 
Injury - Larvae burrow in sapwood of weakened trees.

Distribution - North America.

Reference - Brooks, F. E. U. S. Agr. Dept. Farmers' bul. 1065:5. 1919.

flavicornis Boh. Schn., Anthonomus........................... Curculionidae

Hosts - Crataegus, Solanum, dogwood, and other species.

Distribution - North America.

Reference - Blatchley, W. S., and Leng, C. W. Rhynchophora of north eastern America, p. 298. 1916.

flavicornis Clairv., Ramphus................................ Curculionidae

Synonym - Ramphus oxyacanthae Marsh.

Hosts - Malus, Crataegus oxyacantha, Betula, Salix, Prunus, Populus.

Injury - Larvae mine in leaves.

Distribution - Europe.

References - Heyden, C. von. Berlin. ent. Zeit. 6:63. 1862.

Bargagli, P. Rincofori Europei, p. 251. 1883.

foliacea Lec., Haltica (Apple flea beetle). Fam. Chrysomelidae

Hosts - Malus, Crataegus.

Injury - Beetles and larvae eat many small holes in foliage.

Distribution - North America.

Reference - Murtfeldt, M. E. Insect life 1:74. 1888.

giganteus Krinick., Rhyrechites.........................Fam. Curculionidae

Host - Crataegus oxyacantha.

Distribution - Europe, Asia.

References - Desbrochers, L. Monographie des Rhinomaceridae;.p. 345. 1869.

Bargagli, P. Rincofori Europei, p. 180, 188.1883.

helxines Linn., Crepidodera............................ Fam. Chrysomelidae

Hosts - Crataegus, Salix, Malus, Pyrus, Ulmus, Populus.

Injury - Beetles eat many small holes in leaves.

Distribution - Europe, North America.

References - Blatchley, W. S. Coleoptera of Indiana, p. 1214. 1910.

Slingerland, M. V., and Crosby, C. R. Manual of fruit insects, p. 205. 1914.

icosandriae Scop., Rhynchites.

Fam. Curculionidae

Synonym - Rhynchites conicus Ill.

Hosts - Crataegus oxyacantha, Malus, Pyrus, Prunus, Sorbus.

Injury - Beetles cut off tender twigs. Serious pest in nurseries.

Distribution - Europe, Asia.

References - Kaltenbach, J. H. Pflanzenfeinde, p. 154, 207. ' 1872.

Bargagli, P. Rincofori Europei, p. 188. 1883.

impressifrons Gyll., Polydrusus.............................. Curculionidae

Hosts - Salix, Populus, Crataegus, Quercus, Malus, Pyrus, Corylus, and other species.

Injury - Beetles eat buds, leaves, and tender twigs in May and June.

Distribution - Europe, New York (imported about 1906).

References - Parrott, P. J., and Glasgow, H. New York (Geneva) Agr. Exp. Sta. Tech. bul. 56:7. 1916 .

Pierce, W. D. Journ. econ. ent. 9:424. 1916.

maculicornis Germ., Phyllobius (Green leaf weevil)

Fam. Curculionidae

Hosts - Malus, Pyrus, Prunus, Quercus, Crataegus, Acer.

Injury - Beetle eats into opening buds, and later eats holes in leaves.

Distribution - Europe, Asia.

Reference - Theobald, F. V. Insect pests of fruits, p. 119. 1909. 
marginalis Ill., Systena....

Fam. Chrysomelidae

(See page 1067.)

metasternalis Cr., Tymnes... .

Fam. Chrysomelidae

Host - Crataegus.

Listribution - North America.

Reference - Smith, J. B. Insects of New Jersey, p. 344. 1909.

mixtus Lec., Anthonomopsis. ..

Hosts - Crataegus, Prunus.

Distribution - North America.

Reference - Blatchley, W. S., and Leng, C. W. Rhynchophora of north eastern America, p. 286.1916.

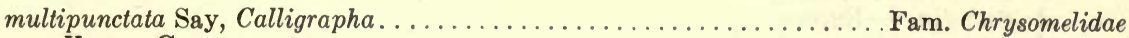
Host - Crataegus.

Distribution - North America.

Reference - Blatchley, W. S. Coleoptera of Indiana, p. 1158. 1910.

naso Lec., Conotrachelus..............................Fam. Curculionidae

Hosts - Crataegus, Quercus virginiana.

Injury - Larva feeds in fruit.

Distribution - North America.

References - Hamilton, J. Can. ent. $21: 34.1889$.

Pierce, W. D. Nebraska State Bd. Agr. Ann. rept. 1906-07:275. 1907.

nebulosus Lec., Anthonomus (Hawthorn blossom weevil)............. Fam. Curculionidae (See page 1068.)

nenuphar Hbst., Conotrachelus (Plum curculio)

Hosts - Prunus, Pyrus, Malus, Cydonia, Crataegus.

Injury - Larvae feed in fruit, and beetles deform fruits by their feeding punctures.

Distribution - North America east of Rocky Mountains.

Reference - Slingerland, M. V., and Crosby, C. R. Manual of fruit insects, p. 243. 1914.

nitidipennis Boh., Magdalis. .

Hosts - Crataegus, Populus, Salix.

Distribution - Europe.

References - Redtenbacher, L. Fauna Austriaca. Die Käfer, p. 759. 1858.

Bargagli, P. Rincofori Europei, p. 196. 1883.

oblongus Linn., Phyllobius...............................Fam. Curculionidae

Hosts - Malus, Crataegus, Populus, Corylus, and other species.

Injury - Beetles eat into opening buds, and later eat leaves.

Distribution - Europe, Asia.

Reference - Bargagli, P. Rincofori Europei, p. 79. 1883.

Theobald, F. V. Insect pests of fruits, p. 119. 1909.

olivaceus Gyll., Rhynchites.............................Fam. Curculionidae

Synonym - Rhynchites comatus Dej.

Hosts - Crataegus, Corylus, Prunus.

Distribution - Europe.

References - Kaltenbaeh, J. H. Pflanzenfeinde, p. 154, 207. 1872.

Bargagli, P, Rincofori Europei, p. 190. . 1883.

pauxillus Germ., Rhynchites.

Hosts - Crataegus oxyacantha, Malus.

Injury - Beetles cut off twigs.

Distribution - Europe. 
References - Kaltenbach, J. H. Pflanzenfeinde, p. 207. 1872.

Theobald, F. V. Insect pests of fruits, p. 118. 1909.

politus Say, Agrilus

Hosts - Crataegus, Salix, Quercus, Corylus.

Injury - Larva tunnels under bark, causing gall-like swellings on twigs of Crataegus and girdling twigs of oak with a spiral tunnel.

Distribution - North America.

References - Smith, J. B. Insects of New Jersey, p. 295. 1909.

Felt, E. P. New York State Mus. Bul. 200:135. 1918.

pomonae Fabr., Apion.

Hosts - Vicia, Crataegus.

Distribution-Europe.

References-Curtis, J. Farm insects, p. 487. 1860.

Bargagli, P. Rincofori Europei, p. 165. 1883.

pomorum Linn., Anthonomus (Apple blossom weevil) .............. Fam. Curculionidae Hosts - Malus, Pyrus, Crataegus.

Injury - Larva feeds within closed fruit bud, destroying it. Often a very serious pest of apple in Europe. Whitehead records shaking 1530 adults from a single tree in two days.

Distribution - Europe, one specimen recorded from Ohio taken among A. nebulosus.

References - Kaltenbach, J. H. Pflanzenfeinde, p. 207. 1872.

Dietz, Wm. G. Amer. Ent. Soc. Trans. 18:204. 1891.

Whitehead, C. Report on injurious insects in Great Britain, p. 44. 1892.

Henschel, G. A. O. Die schädlichen forst- und obstbaum Insekten, p. 571. 1895.

Collinge, W. E. Manual of injurious insects, p. 97. 1912.

posticatus Boh. Schn., Conotrachelus.

.Fam. Curculionidae

Hosts - Crataegus, Prunus, Carya.

Injury - Larva feeds in fruit.

Distribution - North America.

References - Hamilton, J. Can. ent. 21:34. 1889.

Blatchley, W. S., and Leng, C. W. Rhynchophora of north eastern America, p. 477. 1916 .

profundus Lec., Anthonomus.....

Fam. Curculionidae

Hosts - Crataegus, Quercus.

Injury - Larva feeds in fruit.

Distribution - North America.

Reference - Blatchley, W. S., and Leng, C. W. Rhynchophora of north eastern America, p. 290.1916.

pruni Ratz., Eccoptogaster.

Hosts - Malus, Pyrus, Prunus, Crataegus, Ulmus.

Injury - Larva girdle 3 weakened trees by mining in cambium layer.

Distribution - Europe, Asia.

References - Kaltenbach, J. H. Pflanzenfeinde, p. 154. 1872.

Wahl, C. von. Borkenkäfer an den Obstbäumen und ihre Bekämfung. Augustenberg Flugblatt, no. 3, p. 4. 1914.

pruni Linn., Magdalis............................Fam, Curculianidae

Hosts - Prunus, Crataegus, Rosa, and other species,

Injury - Larva tunnels under bark of branches.

Distribution - Europe, Asia. 
References - Bargagli, P. Rincofori Europei, p. 196.1883.

Pierce, W. D. Manual of dangerous insects, p. 132.1917.

pterygomalis Boh., Polydrusus.........................Fam. Curculionidae

Hosts - Crataegus oxyacantha, Prunus, Salix, Betula, Corylus, Fagus.

Injury - Beetles feed on foliage.

Distribution - Europe, Asia.

Reference-Pierce, W. D. Journ. econ. ent. 9:431. 196.

pubescens Melsh., Agriotes.

Fam. Elateridae

(See page 1066.)

pubescens Fabr., Rhynchites.

Synonym - Rhynchites cyanicolor Schr.

Hosts - Crataegus, Corylus, Alnus, Quercus.

Distribution - Europe.

References - Kaltenbach, J. H. Pflanzenfeinde, p. 207. 1872.

Bargagli, P. Rincofori Europei, p. 191. 1883.

quadrigibbus Say, Tachypterus (Apple curculio) ................. Fam. Curculionidae

Hosts - Malus, Crataegus, Amelanchier, Pyrus.

Injury - Larva feeds in fruit, beetles puncture fruit and young twigs.

Distribution - Eastern North America.

References - Brooks, F. E. West Virginia Agr. Exp. Sta. Bul. 126. 1910.

Mitchell, J. B., and Pierce, W. D. Ent. Soc. Washington. Proc. 13:53. 1911.

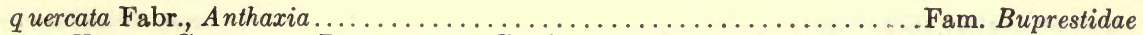

Hosts - Crataegus; Pinus strobus, Cercis, and other species.

Injury - Larva bores in dead or dying branches.

Distribution - North America.

Reference - Knull, Josef N. Ent. news 31:6. 1920.

rufus Ol., Orchestes.

Hosts - Ulmus, Quercus, Salix, Crataegus, Prunus.

Distribution - Europe.

Reference - Bargagli, P. Rincofori Europei, p. 217. 1883.

rugulosus Ratz., Eccoptogaster (Fruit-tree bark beetle)................. Fam. Ipidae

Hosts - Prunus, Cydonia, Malus, Crataegus, Sorbus, Amelanchier.

Injury - Larva and adult mine in cambium layer of weak trees, frequently killing them.

Distribution - Europe, Asia, North America.

References - Gossard, H. A. Ohio Agr. Exp. Sta. Circ. 140. 1913.

Wahl, C. von. Borkenkäfer an den Obstbäumen und ihre Bekämfung. Augustenberg Flugblatt, no. 3, p. 4. 1914.

Swaine, J. M. Can. Agr. Dept. Bul. 14:52. 1918.

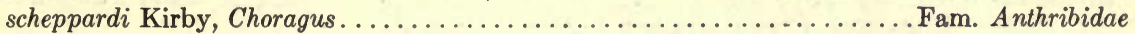

Synonym - Alticopus galeazii Vill.

Host - Crataegus oxyacantha.

Injury - Larva burrows in dying twigs.

Distribution - Europe.

References - Redtenbacher, L. Fauna Austriaca. Die Käfer, p. 674. 1858.

Kaltenbach, J. H. Pflanzenfeinde, p. 208. 1872.

sericeus Schal., Polydrusus............................. Curculionidae

Hosts - Pyrus, Prunus, Crataegus, Malus, Fagus, Salix, Quercus, Alnus, and other species.

Injury - Beetles feed on buds and foliage. 
Distribution - Europe, Asia, recently imported into United States (Indiana).

References - Kaltenbach, J. H. Pflanzenfeinde, p. 179. 1872. Bargagli, P. Rincofori Eurcpei, p. 59. 1883.

Pierce, W. D. Journ. eccn. ent. 9:428. 1916.

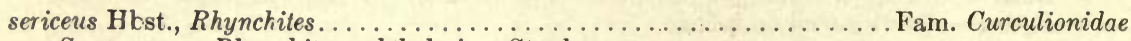

Synonym - Rhynchites ophthalmicus Steph.

Hosts - Crataegus, Corylus, Quercus, Betula.

Listribution - Europe.

References - Kaltenbach, J. H. Pflanzenfeinde, p. 154, 207. 1872.

Bargagli, P. Rincofcri Eurcpei, p. 191. 1883.

sinuatus Oliv., Agrilus (Sinuate pear borer).

Hosts - Pyrus communis, Crataegus, Sorbus.

Injury - Larva tunnels in sapwocd, raking a zigzag mine.

Listribution - Eurcpe, Ncrth Ancerica.

References - Smith, J. B. New Jersey Ägr. Exp. Sta. Ann. rept. 15:550. 1894.

Scrauer, P. Handbuch der Pflanzenkrankheiten 3:487. 1913.

subspinosus Fabr., Mocrodoctylus (Rcse chafer)....................... Scarabaeidae

Hosts - Vitis, Malus, Pyrus, Rcsa, Crataegus, and cther species.

Injury - Beetles feed on fcliage, flowers, and fruit, and are sometimes very injurious. Listribution - North America.

References - Hartzell, F. Z. New York (Geneva) Agr. Exp. Sta. Bul. 331:534. 1910. Slingerland, M. V., and Crcsby, C. R. Manual of fruit insects, p. 397. 1914.

testacea Kirby, Dichelonycha .

Fam. Scarabaeidae

(See page 1067.)

tomentosus Fabr., Byturus (Raspberry beetle).

Hosts - Rubus, Crataegus, Malus, Pyrus.

Injury - Beetles feed on flowers and foliage.

Listribution - Europe.

References - Sorauer, P. Handbuch der Pflanzenkrankheiten 3:472. 1913. Bot. journ. London 5:73. 1917.

tubulatus Say, Idiostethus. Fam. Curculionidae

Hosts - Orchids, Crataegus.

Distribution - North America.

References - Pierce, W. D. Nebraska State Bd. Agr. Ann. rept. 1906-07:284. 1907. Blatchley, W.S., and Leng, C. W. Rhynchophora of north eastern America, p. 404. 1916.

villosula Melsh., Xanthonia Fam. Chrysomelidae (See page 1067.)

vittaticollis Rand., Agrilus.

Hosts - Crataegus, Prunus virginiana, Amelanchier.

Injury - Beetles feed on foliage.

Distribution - Eastern United States.

Reference-Blanchard, F. Amer. ent. 5:32. 1889.

Melanotus sp. Fam. Dermestidae (See page 1066.)

Fam. Elateridae

\section{LEPIDOPTERA}

abbotti Swains, Sphecodina.

Hosts - Vitis, Ampelopsis, Crataegus tomentosa.

Injury - Larvae feed on foliage. 
Distribution - Eastern North America.

References - Packard, A. S. Fifth rept. U. S. Ent. Comm., p. 536. 1890.

Beutenmueller, William. Hawk moths of the vicinity of New York City, p. 12.1903.

achatana Fabr., Olethreutes.

Fam. Tortricidae

Hosts - Crataegus, Malus.

Injury - Larvae roll leaves and eat them.

Distribution - Europe, Asia Minor.

References - Kaltenbach, J. H. Pflanzenfeinde, p. 209.1872.

Theobald, F. V. Insect pests of fruits, p. 81. 1909.

advenella Zk., Rhodophaex.

Fam. Pyralidae

Hosts - Crataegus, Pyrus.

Injury - Larvae tie leaves and eat them.

Distribution - Europe.

References - Kaltenbach, J. H. Pflanzenfeinde, p. 209. 1872.

Spuler, A. Schmetterlinge Europas, 2:216. 1910.

aescularia Schiff., Anisopteryx (March moth) .................. Fam. Geometridae

Hosts - Crataegus, Malus, Prunus, Pyrus, Quercus, Tilia, Ulmus, Acer, and other species.

Injury - Larvae feed on foliage, sometimes defoliating trees.

Distribution - Europe.

Reference - Theobald, F. V. Insect pests of fruits, p. 61. 1909.

americana Harris, Acronycta.............................Fam. Noctuidae

(See page 1073.)

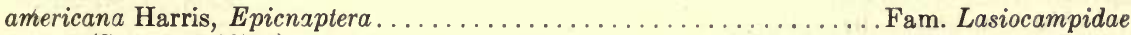

(See page 1075.)

americana Fabr., Malacosoma (Apple tent caterpillar).................. Lasiocampidae

Hosts - Prunus, Malus, Crataegus, Sorbus, Rosa, Amelanchier, Quercus, Salix, and other species.

Injury - Larvae defoliate branches, living within a silken tent.

Distribution - North America.

References - Felt. E. P. New York State Mus. Memoir 82:550. 1906.

Slingerland, M. V., and Crosby, C. R. Manual of fruit insects, p. 112. 1914.

anatipennella Hüb., Coleophora. Fam. Elachistidae

Synonym - Coleophora tiliella Zell.

Hosts - Crataegus, Quercus, Tilia, Corylus, Prunus spinosa.

Injury - Larva eats patches of green tissue from leaf.

Distribution - Europe.

References - Kaltenbach, J. H. Pflanzenfeinde, p. 210. 1872.

Spuler, A. Schmetterlinge Europas, 2:400. 1910.

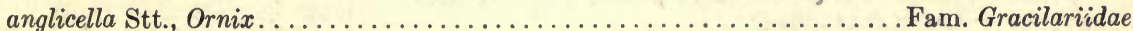

Hosts - Crataegus, Fragaria.

Injury - Larva mines in leaf.

Distribution - Europe, Asia, one record in Massachusetts.

References - Stainton, H. T. Natural history of the Tineina, 8:292. 1864.

Kaltenbach, J. H. Pflanzenfeinde, p. 171. 1872.

Dietz, W. G. Amer. Ent. Soc. Trans. 33:294. 1907.

Spuler, A. Schmetterlinge Europas, 2:410. 1910.

angustiorana Haw., Capua

.Fam. Tortricidae

Hosts - Crataegus, Laurus, Smilax, Pyrus, and other species. 
Injury - Larva ties leaves together and feeds on them.

Distribution - Southern Europe, northern Africa, Asia Minor.

Reference - Spuler, A. Schmetterlinge Europas, 2:246. 1910.

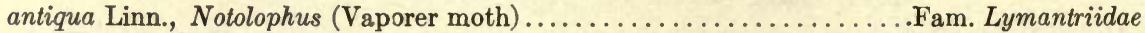

Hosts - Malus, Prunus, Rosa, Crataegus, Ulmus, Tilia, and other species.

Injury - Larvae defoliate branches.

Distribution - Europe, Asia, North America.

References - Packard, A. S. Fifth rept. U. S. Ent. Comm., p. 536. 1890.

Theobald, F. V. Insect pests of fruits, p. 38. 1909.

argyrospila Walk., Archips (Fruit-tree leaf roller) ................. Fam. Tortricidae (See page 1077.)

arthemis Dru., Basilarchia

Hosts - Crataegus, Salix, Tilia, Populus.

Injury - Larvae eat leaves, except midrib, beginning at apex.

Distribution - Eastern United States.

References - French, G. H. Butterflies of the eastern United States, p. 208. 1886.

Edwards, H. U. S. Nat. Mus. Bul. 35:27. 1889.

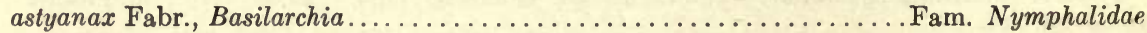

Hosts - Salix, Prunus, Malus, Tilia, Crataegus, and other species.

Injury - Larva eats leaf on both sides of midrib, beginning at apex.

Distribution - Eastern and southern United States.

References - Packard, A. S. $\quad$ Fifth rept. U. S. Ent. Comm., p. 535. 1890.

Holland, W. J. Butterfly book, p. 184. 1898.

aterrima Wck., Nepticula. .Fam. Nepticulidae

Host - Crataegus oxyacantha.

Injury - Larva mines in leaf.

Distribution - Germany.

Reference - Spuler, A. Schmetterlinge Europas, 2:480. 1910.

atricollis Stt., Nepticula ...........................Fam. Nepticulidae

Hosts - Malus malus, Prunus spinosa, Crataegus oxyacantha.

Injury - Larva mines in leaf.

Distribution - Europe.

Reference - Spuler, A. Schmetterlinge Europas, 2:479. 1910.

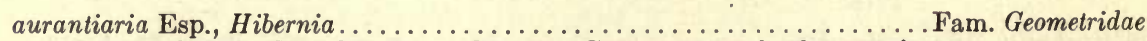

Hosts - Betula, Populus, Rosa, Quercus, Crataegus, and other species.

Injury - Larva eats leaves.

Distribution - Europe.

References - Kaltenbach, J. H. Pflanzenfeinde, p. 209, 218. 1872.

Spuler, A. Schmetterlinge Europas, 2:98. 1910.

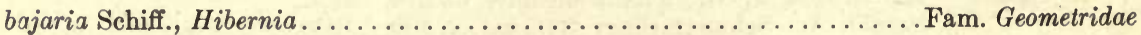

Hosts - Prunus, Pyrus, Crataegus, Ligustrum, Syringa.

Injury - Larva eats foliage.

Distribution - Europe.

References - Kaltenbach, J. H. Pflanzenfeinde, p. 166.1872. Spuler, A. Schmetterlinge Europas, 2:98. 1910.

betulae Zell., Lithocoll tis .

Hosts - Crataegus, Pyrus, Cydonia, Betula.

Injury - Larva mines in upper side of leaf.

Distribution - Europe.

References - Kaltenbach, J. H. Pflanzenfeinde, p. 198.1872.

Spuler, A. Schmetterlinge Furopas, 2:419. 1910. 
betularia Linn., Amphidasis (Pepper-and-salt moth) ................ Fam. Geometridxe Hosts - Malus, Prunus, Crataegus, Quercus, Ulmus, Populus, Betula.

Injury - Larvae defoliate trees in late summer.

Distribution - Europe, Asia, Japan.

Reference - Theobald, F. V. Insect pests of fruits, p. 64. 1909.

bidentata Clerck., Gonodontis (Scalloped hazel moth) ................Fam. Geometridxe Hosts - Corylus, Betula, Prunus, Crataggus, Pyrus, Quercus, and other species.

Injury - Larva feeds on foliage.

Distribution - Europe, Asia, Japan.

Reference - Collinge, W. E. Manual of injurious insects, p. 138. 1912.

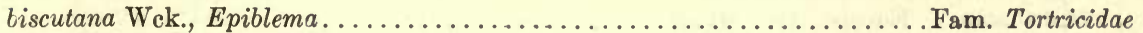
Hosts - Betula, Crataegus oxyacantha.

Injury - Larva ties together terminal clusters of leaves and feeds within.

Distribution - Norway, Finland.

Reference - Spuler, A. Schmetterlinge Europas, 2:283. 1910.

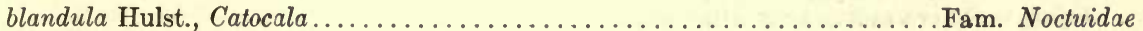
Host - Crataegus.

Injury - Larvae feed on foliage.

Distribution - Eastern United States, Canada.

References - Packard, A. S. Fifth rept. U. S. Ent. Comm., p. 533.1890.

Smith, J. B. Insects of New Jersey, p. 476. 1909.

brumata Linn., Cheimatobia (Winter moth) ...................... Gameomidae

Hosts - Fruit and forest trees (except conifers) and shrubs.

Injury - Larvae defoliate trees and may attack flowers or fruit.

Distribution - Europe. Asia, Greenland.

References - Ormerod, E. A. Manual of injurious insects, p. 338, 360. 1890.

Theobald, F. V. Insect pests of fruits, p. 50. 1909.

Med. Phytopath. Dienst. Wageningen, no. 3. 1916.

cxlanus Hüb., Strymon (Banded hair-streak).

Fam. Lycaenidae

Synonym - Thecla falacer Godart.

Hosts - Crataegus, Quercus, Hicoria.

Injury - Larva eate holes in leaves:

Distribution - United States and Canada.

References - Scudder, S. Butterflies of New England, 2:885. 1839.

Packard, A. S. Fifth rept. U. S. Ent. Comm., p. 536.1890.

caryae Harris, Halisidota (Hickory tussock moth) ................ Fam. Arctiidre

Hoscs - Hicoria, Juglans, Malus, Cydonia, Crataegus, and other species.

Injury - Larvae eat foliage.

Distribuiion - United States east of Rocky Mountains.

Reference - Soule, Caroline G. Psyche 6:15S. 1891.

catax Linn., Eriogaster.

Fam. Lasiocampidae

Hosts - Crataegus, Quercus, Populus, Betula.

Injury - Larvae defoliate branches, which they cover with silken tents.

Distribution - Europe.

Reference - Spuler, A. Schmetterlinge Eurcpas, 1:117. 1908.

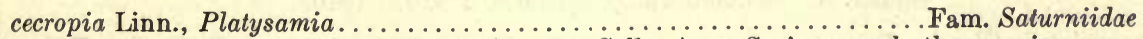
Hosts - Crataegus, Malus, Pyrus, Prunus, Salix, Acer, Syringa, and other species.

Injury - Larva eats leaves.

Distribution - North America east of Rocky Mountains.

References - Packard, A. S. Fifth rept. U. S. Ent. Comm., p. 536.1890.

Dickerson, Mary C. Moths and butterflies, p. 157. 1901. 
cerisolella Pey., Lithocolletis................................. Fam. Gracilariidae

Hosts - Crataegus, Sorbus torminalis.

Injury - Larva mines in leaf on under side.

Distribution - Southern France.

Reference - Spuler, A. Schmetterlinge Europas, 2:415. 1910.

chionosema Zell., Olethreutes...............................Fam. Tortricidae

(See page 1077.)

chrysorrhea Linn., Euproctis (Brown-tail moth)...

Fam. Lymantriidae

Hosts - Cratiegus and most other deciduous trees.

Injury - Larvae defoliate trees.

Distribution - Europe, Asia Minor, New England States.

References - Kaltenbach, J. H. Pflanzenfeinde, p. 208. 1872.

Spuler, A. Schmetterlinge Europss, 1:132. 1908.

clerkella Linn., Lyonetia ..............................Fam. Lyonetiidae

Hosts - Pyrus, Prunus, Cratsegus, Sorbus, Betula.

Injury - Larva makes serpentine mine in leaf.

Distribution - Europe.

Reference - Spuler, A. Schmetterlinge Europas, 2:422. 1910.

coeruleocephala Linn., Liloba (Figure-8 moth).....

Hosts - Malus, Prunus, Cratsegus, and other species.

Injury - Larva eats foliage, sometimes defoliating hawthorn hedges.

Listribution - Europe, Asia.

References - Kaltenbach, J. H. Pflanzenfeinde, p. 208. 1872.

Theobald, F. V. Insect pests of fruits, p. 35. 1909.

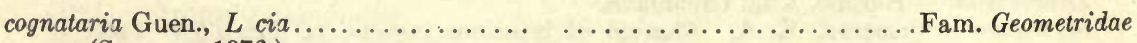

(See page 1076.)

cognatellus Hüb., Yponomeuta (Hedge ermine moth) ............... Fam. Yponomeutidae

Hosts - Crataejus oxyacantha, Euonymus.

Injury - Larva eats leaves, sometimes stripping hedges.

Distribution - Europe.

References - Spuler, A. Schmetterlinge Europas, 2:444. 1910.

Noel, P. Jardinage 4:363. 1914.

concinna A. and S., Schizura (Red-humped apple caterpillar)........... Fam. Notodontidae

Hosts - Molus, Crataegus, Prunus, Pyrus, and other species.

Injury - Larvae defoliate branches, feeding in a colony.

Distribution - North America.

References - Saunders, William. Can. ent. 13:139. 181.

Slingerland, M. V., and Crosby, C. R. Manual of fruit insects, p. 125. 1914.

concomitella Bnks., Lithocolletis..........................Fam. Gracilariidae

Synonym - Lithocolletis pomifoliella Zell.

Hosts - Malus, Cratregus.

Injury - Larva mines in leaf.

Distribution - Europe.

References - Kaltenbach, J. H. Phanzenfeinde, p. 198. 1872.

Spuler, A. Schmetterlinge Europ 3s, 2:415. 1910.

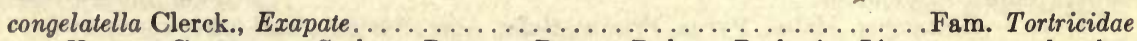
Hosts - Crataegus, Sorbus, Prunus, Pyrus, Rubus, Berberis, Ligustrum, and other species.

Injury - Larva ties leaves together and feeds on them.

Distribution - Europe. 
References - Kaltenbach, J. H. Pflanzenfeinde, p. 210. 1872.

Spuler, A. Schmetterlinge Eurcpas, 2:254. 1910.

contaminana Hüb., Acalla .

Hosts - Cratgegus, Prunus, Pyrus, Malus, Quercus, and other species.

Injury - Larva ties leaves together and feeds on them.

Distribution - Europe.

References - Kaltenbach, J - H. Pflanzenfeinde, p. 209. 1872.

Spuler, A. Schmetterlinge Eurcpas, 2:245. 1910.

corylifoliella Haw., Lithocolletis.

Hosts - Crataegus, Pyrus, Malus, Sorbus.

Injury - Larva mines in leaf.

Distribution - Europe.

Reference - Spuler, A. Schmetterlinge Europas, 2:417. 1910.

crataegana Hüb., Cacoecia................................... Tortricidae

Synonym - Penthina robrana Schiff.

Hosts - Crataegus, Quercus, Betula, Populus, Malus, Cotoneaster, and other species.

Injury - Larva ties leaves together and feeds on them.

Distribution - Europe, Asia.

References - Kaltenbach, J. H. Pflanzenfeinde, p. 209. 1872.

Spuler, A. Schmetterlinge Europas, 2:247. 1910.

crataegella Clem., Lithocolletis............................... Gracilariidue

Hosts - Crataegus, Pyrus, Prunus serotina.

Injury - Larva mines in leaf.

Distribution - North America.

References - Braun, A. F. Amer. Ent. Soc. Trans. 34:301. 1908.

Wilson, H. F. Oregon Agr. Exp. Sta. Bien. crop pest and hort. rept. $2: 119.1915$.

crataegella Linn., Scythropia....... .

Hosts - Crataegus oxyacxntha, Prunus spinosa, Pyrus.

Injury - Larva spins a tent over the branch and eats the leaves within it.

Distribution - Europe.

References - Kaltenbach, J. H. Pflanzenfeinde, p. 169.1872.

Spuler, A. Schmetterlinge Europas, 2:443. 1910.

crataegi Linn., Aporia (Fruit-tree pierid) ........................ Fam. Pieridae

Hosts - Crataegus, Pyrus, Malus, Prunus, Sorbus, Sølix, Quercus, and other species.

Injury - Larva eats foliage, often stripping trees.

Distribution - Europe.

Rejerences - Bechstein, J. M., and. Scharfenberg, G. L. Naturgeschichte der sch :dlichen Forstinsekten, p. 303.1805.

Sasscer, E. R. Journ. econ. ent. 11:126. 1918.

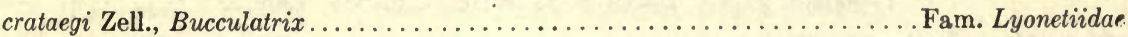

Host - Crataegus.

Injury - Larva mines in leaf and later feeds externally on leaf.

Distribution - Europe.

Reference - Stainton, H. T. Natural history of the Tineina, 7:68. 1862.

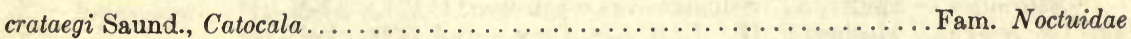

Host - Crataegus.

Injury - Larva feeds on foliagè.

Distribution - Eastern North America.

References - Saunders, William. Can. ent. 8:72. 1876.

Packard, A. S. Fifth rept. U. S. Ent. Comm., p. 532. 1890. 
crataegi Linn., Trichiura .

Hosts - Prunus, Crataegus, Corylus, Betula, Salix, Alnus.

Injury - Larva feeds on foliage.

Distribution - Europe, Asia Minor.

Reference - Spuler, A. Schmetterlinge Europas, 1:114. 1908.

crataegifoliella Clem., Nepticula .

Fam. Nepticulidae

Host - Crataegus uniflora.

Injury - Larva mines in leaf.

Distribution - Eastern United States.

Reference - Packard, A. S. Fifth rept. U. S. Ent. Comm., p. 534. 1890.

crataegifoliella Clem., Ornix................................Fam. Gracilariidae

Host - Crataegus tomentosa.

Injury - Larva mines in leaf.

Distribution - Eastern United States.

References - Packard, A. S. Fifth rept. U. S. Ent. Comm., p. 534. 1890.

Dietz, W. G. Amer. Ent. Soc. Trans. 33:292. 1907.

cuculla Esp., Lophopteryx

Synonym - Notodontx cucullina Hüb.

Hosts - Acer campestre, Crataegus.

Injury - Larva feeds on foliage.

Distribution - Europe.

Reference - Kaltenbach, J. H. Pflanzenfeinde, p. 208. 1872.

cucullatella Linn., Nola

Synonym - Hercyna palliolalis Hüb.

Hosts - Prunus, Malus, Crataegus.

Injury - Larva eats foliage.

Distribution - Europe.

References - Kaltenbach, J. H. Pflanzenfeinde, p. 209. 1872.

Spuler, A. Schmetterlinge Europas, 2:122. 1910.

curvilineella Chamb., Blastodacna (Hawthorn fruit miner)...........Fam. Cosmopterygidae (See page 1030.)

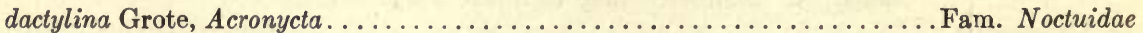

(See page 1073.)

defoliaria Linn., Hibernix (Mottled umber moth).................Fam. Geometridae

Hosts - Malus, Prunus; Betula, Corylus, Quercus, Crataegus, Pyrus, and other species.

Injury - Larvae defoliate trees.

Distribution - Europe.

References - Kaltenbach, J. H. Pflanzenfeinde, p. 163.1872.

Theobald, F. V. Insect pests of fruits, p. 58. 1909.

dispar Linn., Lymantria (Gipsy moth) ..................... Fam. Lymantriidae

Hosts - Species a very general feeder on trees. Crataegus a favored food plant.

Injury - Larvae defoliate trees.

Distribution - Europe, Asia, New England States.

References - Spuler, A. Schmetterlinge Europas, 1:131. 1908.

Mosher, F. H. U. S. Agr. Dept. Bul. 250. 1915.

disstria Hüb., Malacosomx (Forest tent caterpillar).

Hosts - Acer, Quercus, Crataegus, Malus, and other species.

Injury - Larvae defoliate branches, feeding in colonies.

Distribution - North America. 
References - Insect life 3:478. 1890 .

Insect life 4:75. 1891.

Slingerland, M. V., and Crosby, C. R. Manual of fruit insects, p. 119. 1914.

dubitata Linn., Triphosa... Fam. Geometridae

Hosts - Crataegus, Prunus, Rhamnus.

Injury - Larva webs leaves together and feeds on them.

Distribution - Europe, Asia.

References - Kaltenbach, J. H. Pflanzenfeinde, p. 166.1872.

Spuler, A. Schmetterlinge Europas, 2:36. 1910.

ephemeraeformis Haw., Thyridopteryx (Common bagworm)............. Fam. Psychidae

Hosts - Species a very general feeder on trees and shrubs, including Crataegus.

Injury - Larva defoliates trees.

Distribution - North America east of Rocky Mountains.

Reference - Beutenmueller, William. Ent. Amer. 3:157. 1887.

ephippella Fabr., Argyresthia.

Synonym - Argyresthia pruniella Linn.

Hosts - Crataegus, Pyrus, Prunus, Sorbus, Corylus.

Injury - Larva eats leaf and blossom buds.

Distribution - Europe, Asia Minor.

References - Kaltenbach, J. H. Pflanzenfeinde, p. 210. 1872.

Spuler, A. Schmetterlinge Europas, 2:447. 1910.

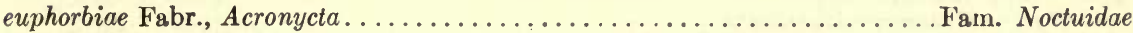

Hosts - Species a general feeder on trees, including Crataegus.

Injury - Larva feeds on foliage.

Distribution - Europe, Asia.

References - Kaltenbach, J. H. Pflanzenfeinde, p. 208. 1872.

Spuler, A. Schmetterlinge Europas, 1:139. 1908.

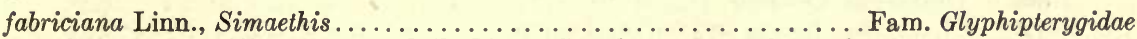

Synonyms - Tinea oxyacanthella Linn., Crambus oxyacanthae Fabr.

Hosts - Urtica, Parietaria, Symphytum, Crataegus.

Injury - Larva feeds in leaf roll.

Distribution - Europe.

References - Bechstein, J. M., and Scharfenberg, G. L. Naturgeschichte der schädlichen Forstinsekten, p. 805. 1805.

Spuler, A. Schmetterlinge Europas, 2:297. 1910.

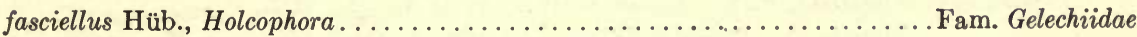

Hosts - Prunus, Crataegus.

Injury - Larva ties leaves together and feeds on them.

Distribution - Europe, Asia Minor.

Reference-Spuler, A. Schmetterlinge Europas, 2:354. 1910.

fletcherella Fern., Coleophora (Cigar case-bearer)................. Fam. Elachistidae

Hosts - Malus, Crataegus, Pyrus, Cydonia.

Injury - Larva eats holes into leaf and makes a small blotch mine around each hole.

Distribution - North America.

References - Hammar, A. G. U. S. Ent. Bur. Bul. 80:33. 1909.

Slingerland, M. V., and Crosby, C. R. Manual of fruit insects, p. 47. 1914.

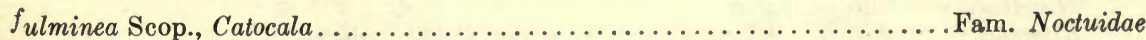

Synonym - Catocala paranympha Linn.

Hosts - Crataegus, Prunus, Pyrus, Quercus.

Injury - Larva eats foliage. 
Distribution - Europe, Asia.

References - Kaltenbach, J. H. Pflanzenfeinde, p. 208. 1872.

Spuler, A. Schmetterlinge Europas, 1:317. 1908.

geminatella Pack., Ornix (Unspotted tentiform leaf miner of apple)....... Fam. Gracilariidae

Synonym - Lithocolletis prunivorella Chamb.

Hosts - Crataegus, Pyrus, Prunus.

Injury - Larva mines in leaf.

Distribution - Eastern United States.

Reference - Haseman, L. Journ. agr. res. 6:289. 1916.

glaucatus Schiff., Cilex.

Hosts - Prunus, Crataegus.

Injury - Larva feeds on foliage.

Distribution - Europe, Asi?.

References Kaltenbach, J. H. Pflanzenfeinde, p. 208. 187.

Spuler, A. Schmetterlinge Europas, 1:107. 1908.

gothica Linn., Taeniocampa

Fam. Noctuidae

Hosts - Crataegus, Tilia, Quercus, and other species.

Injury - Larva feeds on foliage.

Distribution - Europe, Asi\%.

References - Kaltenbach, J. H. Pflanzenfeinde, p. 208. 1872.

Spuler, A. Schmetterlinge Europas, 1:239. 1908.

gratiosella Stt., Nepticula

Host - Crataegus oxyacantha.

Injury - Larva mines in leaf.

Distribution - Europe.

Reference - Spuler, A. Schmetterlinge Eurcpas, 2:476. 1910.

grotiana T., Dichelia....

Hosts - Crataegus, Quercus, Ulmus, Rubus, and other species.

Injury - Larva ties leaves and feeds on them.

Distribution - Europe, Asia Minor.

Reference - Spuler, A. Schmetterlinge Eurcpes, 2:246. 1910.

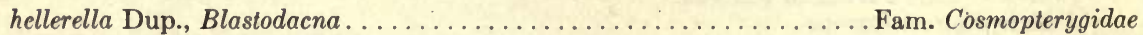

Hosts - Crataegus, Malus, Pyrus.

Injury - Larva tunnels in fruit of Crataegus and in fruit spurs and buds of apple.

Distribution - Europe.

References - Theobald, F. V. Insect pests of fruits, p. 92. 1 1C09.

Spuler, A. Schmetterlinge Eurcpas, 2:387. 1910.

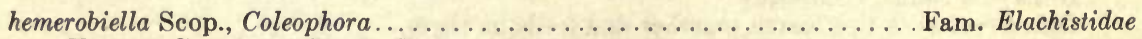

Hosts - Crataegus, Pyrus, Prunus.

Injury - Larva eats star-shaped area from under side of leaf.

Distribution - Europe.

References - Kaltenbach, J. H. Pflanzenfeinde, p. 210. 1872.

Spuler, A. Schmetterlinge Europas, 2:400. 1910.

heparana Schiff., Pandemis............................... ortricidae

Hosts - Crataegus, Prunus, Sorbus, Malus, Alnus, Betula, Fagus, and other species.

Injury - Larva rolls leaf and feeds within the roll.

Distribution - Europe, Japan.

Reference - Spuler, A. Schmetterlinge Europas, 2:249. 1910.

holmiana Linn., Acalla.

Hosts - Crataegus, Rosa, Prunus, Malus, Pyrus, Quercus.

Fam. Tortricidce 
Injury - Larva ties leaves together and feeds on them.

Distribution - Europe.

Reference - Spuler, A. Schmetterlinge Europas, 2:244. 1910.

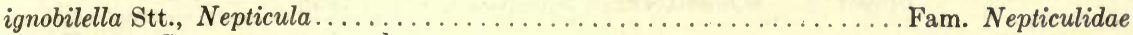

Host - Crataegus oxyacantha.

Injury - Larva mines in leaf.

Distribution - Europe.

References - Kaltenbach, J. H. Pflanzenfeinde, p. 211. 1872.

Sp sler, A. Schmetterlinge Europas, 2:477. 1910.

incerta Hufn., Taeniocampa.

Fam. Noctuidae

Synonym - Taenioc mpa instabilis $\mathrm{Hüb}$.

Hosts - Crataegus, Salix, Prunus, Quercus, Malus, and other species.

Injury - Larva eats leaves, and sometimes eats holes in apple fruit.

Distribution - Europe, Asia, South America.

References - Kaltenbach, J. H. Pflanzenfeinde, p. 208. 1872.

Theobald, F. V. Insect pests of fruits, p. 66.1909.

indigenella Zell., Mineola (Leaf crumpler).................... Fam. Pyiralidae

Synonyms - Acrobasis nebulella Riley, Phycita nebulo Walsh.

Hosts - Malus, Crataegus, Hicoria pecan, and other species.

Injury - Larva feeds on leaves, living in a case composed of leaf particles and silk.

Distribuiion - North America.

Reference-Riley, C. V. Fourth Missouri report, p. 42. 1872.

integerrima G. and R., Datana (Black-walnut caterpillar)............ Fam. Notodontidae

Hosts - Juglans, Hicoria, Malus, Crataegus, and other species.

Injury - Larvae defoliate branches, feeding in a colony.

Distribution - Eastern United States.

Reference - Packard, A. S. Nat. Acad. Sci. Memoir 1:120. 1895.

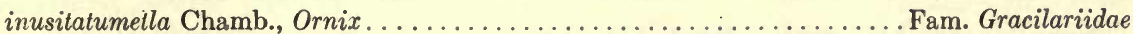

Host - Crataegus.

Injury - Larva mines in upper surface of leaf.

Distribution - Eastern United States.

References - Chambers, V. T. Can. ent. 5:48. 1873.

Packard, A. S. Fifth rept. U. S. Ent. Comm., p. 536. 1890.

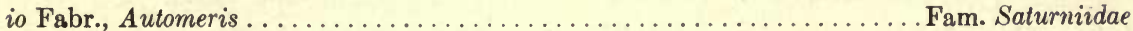

(See page 1073.)

janthinana Dup., Grapholitha

Fam. Tortricidae

Synonym - Tortrix incisanx Schiff.

Host - Crataegus.

Injury - Larva tunnels in fruit, then in twigs.

Distribution - Europe, Asia Minor.

References - Kaltenbach, J. H. Pflanzenfeinde, p. 210. 1872.

Spuler, A. Schmetterlinge Europas, 2:294. 1910.

lacustrata Guen., Mesoleuca .

Fam. Geometridae

Hosts - Rubus, Betula, Crataegus, Salix.

Injury - Larva feeds on foliage.

Distribution - Northeastern North America, Europe.

References - Packard, A. S. A monograph of the geometrid moths of the United States, p. 158.1876.

Smith, J. B. Insects of New Jersey, p. 497. 1909.

lanestris Linn., Eriogaster............................. Lasiocampidae

Hosts - Prunus, Crataegus, Betula, Tilia, Salix. 
Injury - Larvae defoliate branches, feeding gregariously in a white tent of silk. Distribution - Europe, Asia.

References - Kaltenbach, J. H. Pflanzenfeinde, p. 208. 1872. Spuler, A. Schmetterlinge Europas, 1:117. 1908.

leucatella Clerck., Recurvaria...

Hosts - Crataegus, Pyrus, Prunus, Sorbus.

Injury - Larva ties leaves together and feeds on them.

Distribution - Europe.

References - Kaltenbach, J. H. Pflanzenfeinde, p. 210. 1872.

Spuler, A. Schmetterlinge Europas, 2:356. 1910.

leucophaearia Schiff., Hibernia . Fam. Geometridae

Hosts - Quercus, Crataegus, Prunus, and other species.

Injury - Larva eats foliage.

Distribution - Europe, Asia, Japan.

References - Kaltenbach, J. H. Pflanzenfeinde, p. 209. 1872.

Spuler, A. Schmetterlinge Europas, 2:98. 1910.

leucostigma A. and S., Hemerocampa (White-marked tussock caterpillar)..Fam. Lymantriidae (See page 1075.)

limbata Haw., Nematocampa

Synonym - Nematocampa filamentaria Guen.

Hosts - Crataegus, Fragaria.

Injury - Larva eats foliage.

Distribution - North America.

References - Packard, A.S. A monograph of the geometrid moths of the United States, p. 471. 1876.

Packard, A. S. Fifth rept. U. S. Ent. Comm., p. 536. 1890.

parops Bdv. and Lec., Strymon (Striped hair-streak) .............. Fam. Lycaenidae Hosts - Malus, Crataegus, Prunus, Ámelanchier, Salix, Quercus, and other species.

Injury - Larva eats entire leaf and sometimes bores into fruit.

Distribution - United States, Canada.

References - Scudder, S. Butterflies of New England, 2:877. 1889.

Packard, A. S. Fifth rept. U. S. Ent. Comm., p. 536. 1890.

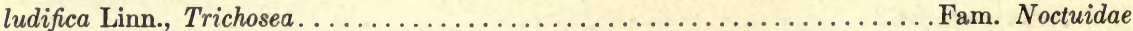

Hosts - Sorbus, Crataegus, Malus.

Injury - Larva eats leaves.

Distribution - Europe.

Reference - Spuler, A. Schmetterlinge Europas, 1:135. 1908.

lunaria Schiff., Selenia.

Fam. Geometridae

Hosts - Malus, Prunus, Crataegus, and other species.

Injury - Larva eats leaves.

Distribution - Europe, Asia.

Reference-Kaltenbach, J. H. Pflanzenfeinde, p. 165.1872.

lutarea Haw., Swammerdamia Fam. Yponomeutidae

Synonym - Swammerdamia oxyacanthella Dup.

Hosts - Crataegus, Sorbus.

Injury - Larva eats parenchymous tissue of leaves, which it ties together.

Distribution - Europe.

References - Kaltenbach, J. H. Pflanzenfeinde, p. 210, 782. 1872.

Spuler, A. Schmetterlinge Europas, 2:445. 1910. 
luteicoma G. and R., Acronycta. (See page 1073.)

Fam. Noctuidae

luteolata Linn., Opisthograptis... .

Synonym - Rumia crataegata Linn.

Hosts - Crataegus, Prunus, Malus, Pyrus, Sorbus.

Injury - Larva eats foliage.

Distribution - Europe, Asia, northern Africa.

Reference - Kaltenbach, J. H. Pflanzenfeinde, p. 165.1872.

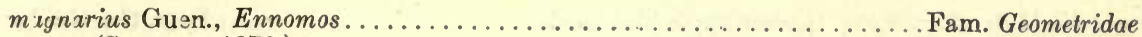

(See page 1076.)

malifoliella Clem., Tischerix (Apple trumpet leaf-miner) . . . . . . . . . . Fam. Gracilariidae

Hosts - Malus, Crataegus.

Injury - Larva mines in upper side of leaf, widening the mine gradually as it grows.

Distribution - North America.

References - Packard, A. S. Fifth rept. U. S. Ent. Comm., p. 536. 1890.

Quaintance, A. L. U. S. Ent. Bur. Bul. 68:23. 1908.

malimalifoliella Braun, Lithocolletis (Spctted tentiform leaf miner of apple). Fam. Gracilariidae

Hosts - Malus, Cydonia, Crataegus mollis.

Injury - Larva mines in under side of leaf.

Distribution - Eastern United. States.

Reference-Braun, A. F. Amer. Ent. Scc. Trans. 34:300. 1908.

malivorella Riley, Coleophora (Pistol case-bearer) ................. Fam. Elachistidae (See page 1079.)

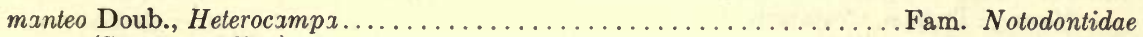

(See page 1074.)

marginaria Borckh., Hibernia. . . . . . . . . . . . . . . . . . . . . . Fam. Geometridae

Hosts - Crataegus, Betula, Quercus, Tilia, Populus, and other species.

Injury - Larva eats foliage.

Distribution - Europe, Asia.

References - Spuler, A. Schmetterlinge Europas, 2:99. 1910.

Pierce, W. D. Manual of dangerous insects, p. 132.1917.

melinus Hüb., Strymon (Common hair-streak) ................... Fam. Lycaenidae

Hosts - Hops, beans, Crataegus, and other species.

Injury - Larva eats leaves and sometimes bores into fruit.

Distribution - North America, Central America.

References - Scudder, S. Butterflies of New England, 2:850. 1889.

Packard, A. S. Fifth rept. U. S. Ent. Comm., p. 535. 1890.

Crosby, C. R., and Leonard, M. D. Manual of vegetable garden insects, p. 84. 1918.

ministra Dru., Datana (Yellow-necked apple caterpillar) ............. Fam. Notodontidae

(See page 1075.)

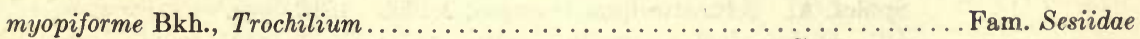

Hosts - Malus malus, Pyrus communis, Prunus domestica, Crataegus.

Injury - Larva tunnels under bark of unhealthy trees.

Distribution - Europe, Asia Minor.

Reference - Spuler, A. Schmetterlinge Europas, 2:310. 1910.

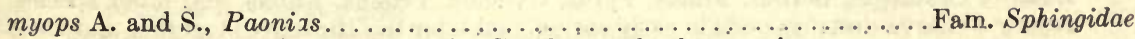

Hosts - Prunus, Crataegus, Salix, Corylus, and other species.

Injury - Larva eats leaves. 
Distribution - Eastern United States.

Reference - Packard, A. S. Fifth rept. U. S. Ent. Comm., p. 525, 536. 1890.

naevana Hüb., Rhopobota ....................................... Tortricidae

Hosts - Prunus, Crataegus, Malus, Rhamnus, Sorbus, Ilex, and other species.

Injury - Larva eats leaves of new shoots and ties them together.

Distribution - Europe.

References - Kaltenbach, J. H. Pflanzenfeinde, p. 210. 1872. Spuler, A. Schmetterlinge Europas, 2:273. 1910.

nanella Hüb., Recurvaria (Lesser apple bud moth)

Fam. Gelechiidae

Synonym - Recurvaria crataegella Busck.

Hosts - Crataegus, Malus, Pyrus, Prunus.

Injury - Larvae destroy opening buds, and mine in leaves in late summer.

Distribution - Europe, North America.

References - Scott, E. W., and Paine, J. H. U. S. Agr. Dept. Bul. 113. 1914.

Sanders, G. E., and Dustan, A. G. Canada Agr. Dept., Ent. Branch. Bul. 16:33. 1919.

neustria Linn., Malacosoma (Lackey moth) .................. Fam. Lasiocampidae

Hosts - Malus, Pyrus, Prunus, Crataegus, Populus, Betula, Quercus, and other species.

Injury - Larva eats leaves, frequently defoliating fruit trees, and builds silken tent over colony.

Distribution - Europe, Asia.

References - Spuler, A. Schmetterlinge Europas, 1:115. 1908.

Theobald, F. V. Insect pests of fruits, p. 30. 1909.

nitidella Fabr., Argyresthia (Cherry fruit moth).............. Fam. Yponomeutidae

Hosts - Prunus, Crataegus.

Injury - Larva destroys young shoots of hawthorn, and bores into cherry fruit.

Distribution - Europe.

References - Kaltenbach, J. H. Pflanzenfeinde, p. 211.1872.

Theobald, F. V. Insect pests of fruits, p. 192.1909.

Spuler, A. Schmetterlinge Europas, 2:447. 1910.

nitidella Hein., Nepticula.

Fam. Nepticulidae

Host - Crataegus oxyacantha.

Injury - Larva mines in leaf.

Distribution - Southwestern Germany.

Reference - Spuler, A. Schmetterlinge Europas, 2:474. 1910.

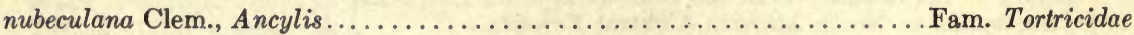
(See page 1077.)

nubilana Hüb., Cnephasia.

Fam. Tortricidae

Hosts - Cratregus, Pyrus, Prunus, Malus, Betula.

Injury - Larva feeds between leaves tied together with silk.

Distribution - Europe.

References - Kaltenbach, J. H. Pflanzenfeinde, p. 209.1872.

Spuler, A. Schmetterlinge Europas, 2:253. 1910.

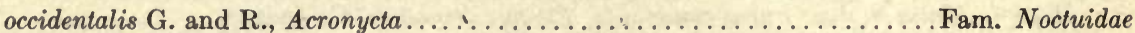

(See page 1074.)

ocellana Fabr., Tmetocera (Bud moth) .......................Fam. Tortricidae

Hosts - Crataegus, Sorbus, Malus, Pyrus, Cydonia, Prunus, Rubus, and other species.

Injury - Larva destroys buds in early spring, and later ties the leaves together and feeds on them.

Distribution - Europe, North America. 
References - Kaltenbach, J. H. Pflanzenfeinde, p. 192. 1872.

Slingerland, M. V. Cornell Univ. Agr. Exp. Sta. Bul. 107. 1896.

Theobald, F. V. Insect pests of fruits, p. 82. 1909.

olexgina Fabr., Valeria. .

Hosts - Crataegus, Prunus.

Injury - Larva feeds on foliage at night.

Listribution - Southern Europe, Asia Minor.

Reference - Spuler, A. Schmetterlinge Europas, 1:185. 1908.

oreasella Clem., Argyresthia .................................. Yponomeutidae (See page 1078.)

oxyacanthae Frey, Lithocolletis

Host - Crataegus oxyacantha.

Fam. Gracilariidae

Injury - Larva mines in under side of leaf.

Distribution - Europe.

References - Kaltenbach, J. H. Pflanzenfeinde, p. 211. 1872.

Spuler, A. Schmetterlinge Europas, $2: 415.1910$.

oxyacanthae Linn., Miselia...............................Fam. Noctuidae

Host - Crataegus oxyacantha.

Injury - Larva eats foliage at night.

Distribution - Europe, Asia Minor.

References - Bechstein, J. M., and Scharfenberg, G. L. Naturgeschichte der. schädlichen Forstinsekten, p. 504. 1805.

Spuler, A. Schmetterlinge Europas, 1:204. 1908.

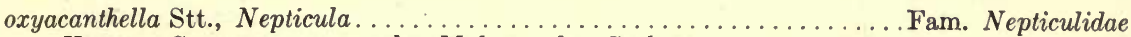

Hosts - Crataegus oxyacantha, Malus malus, Sorbus.

Injury - Larva mines in leaf on upper side.

Distribution - Europe.

References - Kaltenbach, J. H. Pflanzenfeinde, p. 199. 1872.

Spuler, A. Schmetterlinge Europas, 2:474. 1910.

padellus Linn., Yponomeuta (Hawthorn ermine moth).............Fam. Yponomeutidae Synonym - Hyponomeuta padella Linn.

Hosts - Crataegus, Prunus, Vitis.

Injury - Larvae mine in leaves while young, then skeletonize leaves while living colonially in tents.

Distribution - Europe, North America (recently imported).

References - Theobald, F. V. Insect pests of fruits, p. 86. 1909.

Parrott, P. J. Journ. econ. ent. 11:55. 1918.

pariana Clerck., Simaethis. . .

Hosts - Malus, Sorbus, Crataegus, Betula, Prunus.

Injury - Larva makes a slight web over the leaf, then skeletonizes it.

Distribution - Europe, Asia Minor, North America (recently imported).

References - Spuler, A. Schmetterlinge Europas, 2:297. 1910.

Felt, E. P. New York State Mus. Bul. 202:33. 1917.

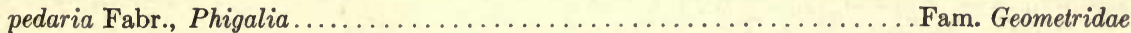

Hosts - Pyrus, Quercus, Betula, Prunus, Crataegus, and other species.

Injury - Larva eats foliage.

Distribution - Europe, Asia.

References - Kaltenbach, J. H. Pflanzenfeinde, p. 164. 1872.

Spuler, A. Schmetterlinge Europas, 2:100. 1910. 
podalirius Linn., Papilio.................................... Papilionidae

Hosts - Crataegus, Sorbus, Prunus, Amygdalus.

Injury - Larva eats foliage.

Distribution - Southern and central Europe, Asia Minor.

Reference - Spuler, A. Schmetterlinge Europas, 1:2. 1908.

polygama Guen., Catocala......

Host - Crataegus.

Injury - Larva feeds on foliage.

Distribution - Eastern North America.

References - Saunders, William. Can. ent. 8:72. 1876.

Edwards, H. U. S: Nat. Mus. Bul. 35:97. 1889.

polyphemus Cram., Telea

Fam. Saturniidae

Hosts - Quercus, Ulmus, Juglans, Hicoria, Tilia, Betula, Rosa, Crataegus, and others.

Injury - Larva feeds on foliage.

Distribution - North America.

References - Packard, A. S. Fifth rept. U. S. Ent. Comm., p. 536. 1890.

Dickerson, Mary C. Moths and butterflies, p. 169. 1901.

pometeria Peck, Alsophila (Fall cankerworm). ...

Fam. Geometridae

(See page 1076.)

pomifoliella Clem., Bucculatrix (Ribbed-cocoon-maker of apple).......... Fam. Lyonetiidae (See page 1079.)

pomonella Linn., Cydia (Codling moth)... Fam. Tortricidae

Hosts - Malus, Pyrus, Cydonia; occasionally Crataegus, Rosa, Prunus, Juglans regia.

Injury - Larva bores in fruit.

Distribution - Europe, Asia, North America, Africa, Australia.

References - Bruner, L. Nebraska State Hort. Soc. Rept. 1894:216. 1894.

Slingerland, M. V., and Crosby, C. R. Manual of fruit insects, p. 10. 1914.

populi Linn., Poecilocampa.............................Fam. Lasiocampidae

Hosts - Populus, Tilia, Quercus, Ulmus, Betula, Salix, Crataegus, Malus, and other species.

Injury - Larva eats foliage.

Distribution - Europe, Asia.

References - Kaltenbach, J. H. Pflanzenfeinde, p. 208. 1872.

Theobald, F. V. Insect pests of fruits, p. 34. 1909.

porrinata Zell., Nemoria.

Hosts - Corylus, Crataegus, and other species.

Injury - Larva eats leaves.

Distribution - Europe.

References - Kaltenbach, J. H. Pflanzenfeinde, p. 208. 1872.

Spuler, A. Schmetterlinge Europas, 2:4. 1910.

praefica Grote, Prodenia (Yellow-striped army worm)

Hosts - Medicago sativa, Vitis, Crataegus, and other species.

Injury - Larva eats foliage.

Distribution - Pacific coast of the United States.

References - Essig, E. O. Injurious and beneficial insects of California, p. 401. 1915. Crosby, C. R., and Leonard, M. D. Manual of vegetable garden insects, p. 295.1918. 
prunetorum Stt., Nepticula

Hosts - Prunus, Crataegus.

Injury - Larva mines in leaf.

Distribution - Europe, Asia Minor.

Reference-Spuler, A. Schmetterlinge Europas, 2:476. 1910.

pruniana Hüb., Argyroploce. Fam. Tortricidae

Hosts - Prunus, Sorbus, Rosa, Salix, Crataegus.

Injury - Larva ties leaves together and feeds on them.

Distribution - Europe, Asia Minor.

Reference-Spuler, A. Schmetterlinge Europas, 2:265. 1910.

prunivera Walsh, Laspeyresia (Lesser apple worm) .

Hosts - Crataegus, Malus, Prunus.

Injury - Larva bores in fruit.

Distribution - North America east of Rocky Mountains.

Reference - Quaintance, A. L. U. S. Ent. Bur. Bul. 68:49. 1908.

psi Linn., Acronycta (Dagger moth) . . . . . . . . . . . . . . . . . Fam. Noctuidae

Hosts - Malus, Prunus, Crataegus, Salix, Rosa, and other species.

Injury - Larva eats foliage.

Distribution - Europe, Asia, Japan.

References - Kaltenbach, J. H. Pflanzenfeinde, p. 208.1872.

Theobald, F. V.' Insect pests of fruits, p. 41. 1909.

pudibunda Linn., Dasychira (Red-tail moth)....................Fam. Lymantriidae

Hosts - Species a general feeder on fruit and forest trees. Crataegus a favored food plant.

Injury - Larva eats foliage.

Distribution - Europe, Asia.

References - Spuler, A. Schmetterlinge Europas, 1:129. 1908.

Sorauer, P. Handbuch der Pflanzenkrankheiten, 3:384. 1913.

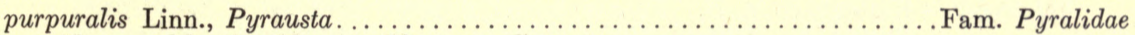

Hosts - Mentha, Nepeta, Plantago, Crataegus.

Injury - Larva feeds on leaves spun together with silk.

Distribution - Europe, Asia.

References - Kaltenbach, J. H. Pflanzenfeinde, p. 209. 1872.

Spuler, A. Schmetterlinge Europas, 2:236. 1910.

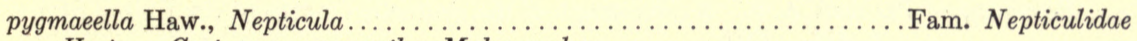

Hosts - Crataegus oxyacantha, Malus malus.

Injury - Larva mines in leaf.

Distribution - Europe.

References - Kaltenbach, J. H. Pflanzenfeinde, p. 199.1872.

Spuler, A. Schmetterlinge Europas, 2:473. 1910.

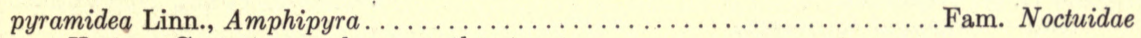

Hosts - Crataegus and many other trees.

Injury - Larva eats foliage.

Distribution - Europe, Asia, East Indies.

References - Kaltenbach, J. H. Pflanzenfeinde, p. 208. 1872.

Spuler, A. Schmetterlinge Europas, 1:238. 1908.

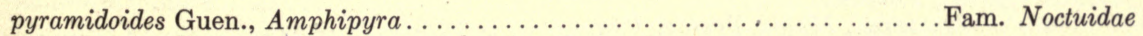

Hosts - Crataegus and many other trees.

Injury - Larva eats foliage.

Distribution - North America.

Reference - Packard, A. S. Fifth rept. U. S. Ent. Comm., p. 171, 536. 1890. 


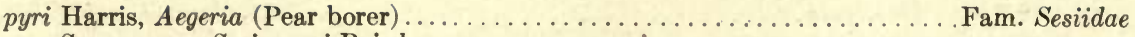
Synonym - Sesia pyri Boisd.

Hosts - Pyrus, Malus, Crataegus, Amelanchier, Prunus.

Injury - Larva burrows in bark and sapwood.

Distribution - Eastern United States.

Reference - Brooks, F. E. U. S. Agr. Dept. Bul. 887. 1920.

pyrina Linn., Zeuzera (Leopard moth)...

Fam. Cossidae

Synonym - Zeuzera aesculi Linn.

Hosts - Pyrus, Malus, Prunus, Crataegus, Fraxinus, Populus, Betula, Ulmus, and other species.

Injury - Larva mines in solid healthy wood of branches.

Distribution - Europe, Asia, Japan, North America.

References - Lintner, A. J. Ninth report on injurious insects of New York, p. 426. 1893.

Theobald, F. V. Insect pests of fruits, p. 46. 1909.

quadrifasciana Fern., Eulia .

(See page 1078.)

quercifolia Linn., Gastropacha (Lappet moth) . ................. Fam. Lasiocampidae

Hosts - Malus, Pyrus, Prunus, Crataegus, Quercus, and other species.

Injury - Larviae defoliate branches, especially of nursery trees, in spring.

Distribution - Europe, Asia.

References - Kaltenbach, J. H. Pflanzenfeinde, p. 208. 1872.

Spuler, A. Schmetterlinge Europas, 1:122. 1908.

Collinge, W. E. Manual of injurious insects, p. 137. 1912.

quercus Linn., Lasiocampa ......................... Fam. Lasiocampidae

Hosts - Crataegus, Quercus, Betula, Salix, and other species.

Injury - Larva eats foliage.

Distribution - Europe, Asia.

References - Kaltenbach, J. H. Pflanzenfeinde, p. 208. 1872.

Spuler, A. Schmetterlinge Europas, 1:118. 1908.

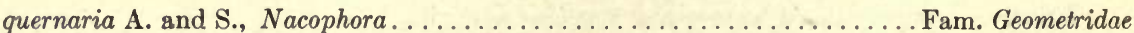

Hosts - Quercus, Crataegus, and other species.

Injury - Larva eats foliage.

Distribution - Eastern North America.

References - Packard, A. S. A monograph of the geometrid moths of the United States, p. 411.1876.

Edwards, H. U. S. Nat. Mus. Bul. 35:106. 1889.

radcliffei Ḧarv., Acronycta. Fam. Noctuidae

(See page 1074.)

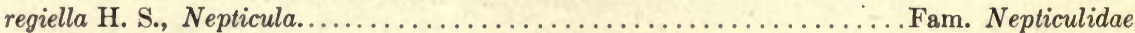

Host - Crataegus oxyacantha.

Injury - Larva mines in leaf.

Distribution - Europe.

References - Kaltenbach, J. H. Pflanzenfeinde, p. 211. 1872.

Spuler, A. Schmetterlinge Europas, 2:475. 1910.

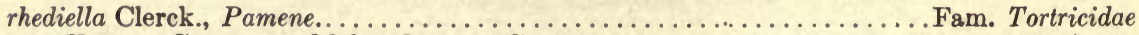

Hosts - Crataegus, Malus; Prunus, Cornus.

Injury - Larva feeds in fruit of Crataegus and also eats leaves.

Distribution - Europe, Asia Minor.

References - Theobald, F. V. Insect pests of fruits, p. 80. 1909.

Spuler, A. Schmetterlinge Europas, 2:296. 1910. 
ribeana Hüb., Pandemis ......................................... Tortricidae

Hosts - Crataegus, Rosa, Prunus, Malus, Pyrus, Quercus, Sorbus, and other species.

Injury - Larva ties several leaves together and feeds within.

Distribution - Europe, Asia, Japan, East Indies.

Reference - Spuler, A. Schmetterlinge Europas, 2:249.' 1910.

rosaceana Harris, Cacoecia (Oblique-banded leaf roller) . ............... Fam. Tortricidae

Hosts - Crataegus, Malus.

Injury - Larvae tie leaves together and feed on them.

Distribution - North America.

References - Essig, E. O. Injurious and beneficial insects of California, p. 441. 1915.

Sanders, G. E., and Dustan, A. G. Canada Agr. Dept., Ent. Branch. Bul. 16:30. 1919.

rosana Linn., Cacoecia

Synonym - Tortrix laevigana Schiff.

Fam. Tortricidae

Hosts - Malus, Crataegus, Pyrus, Prunus, and other species.

Injury - Larvae tie leaves together and feed on them.

Distribution - Europe, Asia Minor, North America.

References - Theobald, F. V. Insect pests of fruits, p. 80. 1909.

Sorauer, P. Handbuch der Pftanzenkrankheiten, 3:299. 1913.

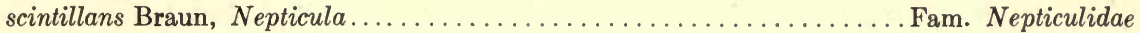

Host - Crataegus mollis.

Injury - Larva mines in leaf.

Distribution - Ohio.

Reference - Braun, A. F. Amer. Ent. Soc. Trans. 43 :167. 1917.

scitella Zell., Cemiostoma (Pear leaf blister moth) . . . . . . . . . . . . . Fam. Lyonetiidae

Hosts - Crataegus, Pyrus, Prunus, Sorbus.

Injury - Larva mines in leaf.

Distribution - Europe, Asia Minor.

References - Kaltenbach, J. H. Pflanzenfeinde, p. 197. 1872.

Theobald, F. V. Insect pests of fruits, p. 330. 1909.

Spuler, A. Schmetterlinge Europas, 2:223. 1910.

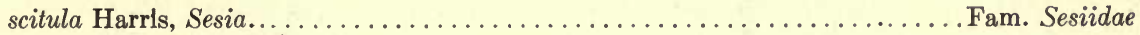
(See page 1076.)

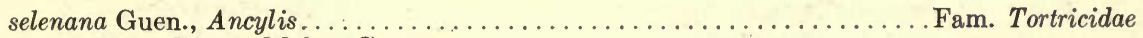

Hosts - Pyrus, Malus, Crataegus.

Injury - Larva ties leaves together and feeds within.

Distribution - Europe, Asia Minor.

Reference - Spuler, A. Schmetterlinge Europas, 2:270. 1910.

signatana Dgl., Steganoptycha.

Fam. Tortricidae

Synonym - Grapholitha kroesmanniana Hein.

Hosts - Prunus, Crataegus.

Injury - Larva eats young terminal leaves after tying them with silk.

Distribution - Europe.

References - Kaltenbach, J. H. Pflanzenfeinde, p. 209. 1872.

Spuler, A. Schmetterlinge Europas, 2:276. 1910.

similis Fuessl., Porthesia (Gold-tail moth). Fam. Lymantriidae

Synonym - Liparis auriflua Hüb.

Hosts - Crataegus and most other fruit and non-coniferous forest trees.

Injury - Larva eats foliage.

Distribution - Europe. 
References - Kaltenbach, J. H. Pflanzenfeinde, p. 208. 1872.

Spuler, A. Schmetterlinge Europas, 1:133. 1908.

sphinx Hufn., Brachionycha

Fam. Noctuidae

Synonym - Asteroscopus cassinia S. V.

Hosts - Quercus, Populus, Malus, Prunus, Crataegus, and other species.

Injury - Larva eats foliage.

Distribution - Europe, Asia Minor.

References - Kaltenbach, J. H. Pflanzenfeinde, p. 208. 1872.

Spuler, A. Schmetterlinge Europas, 1:203. 1908.

spiniana Dup., Pamene. Fam. Tortricidae

Hosts - Crataegus, Prunus, Alnus.

Injury - Larva feeds in blossom, destroying it.

Distribution - Europe, northern Africa.

Reference - Spuler, A. Schmetterlinge Europas, 2:295. 1910.

splendoriferella Clem., Coptodisca (Resplendent shield-bearer).......... Fam. Elachistidae

Hosts - Malus, Crataegus, Prunus serotina, Pyrus, Cydonia.

Injury - Larva mines in leaf and cuts out a small piece of the leaf for its case.

Distribution - Northeastern United States.

References - Packard, A. S. Fifth rept. U. S. Fnt. Ccrm., p. 536.1890.

Slingerland, M. V., and Crosby, C. R. Manual of fruit insects, p. 75. 1914.

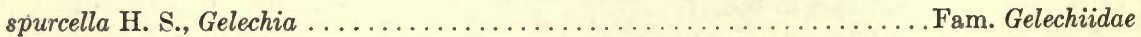

Hosts - Prunus spinosa, Crataegus oxyacantha.

Injury - Larva rolls leaves.

Distribution - Europe, Asia Minor.

Reference - Spuler, A. Schmetterlinge Europas, 2:361. 1910.

steinkelneriana Schiff., Epigraphia .

Fam. Gelechiidae

Hosts - Crataegus, Sorbus, Prunus spinosa, Fraxinus.

Injury - Larva ties leaves together and eats them.

Distribution - Europe.

References - Kaltenbach, J. H. Pflanzenfeinde, p. 210. 1872.

Spuler, A. Schmetterlinge Europas, 2:332. 1910.

stimulea Clem., Sibine (Saddle-back caterpillar) .................. Fam. Limacodidae

Hosts - Species a general feeder on fruit and forest trees, including Crataegus.

Injury - Larva eats foliage.

Distribution - Eastern North America.

References - Beutenmüller, William. Ent. Amer. 4:75. 1888.

Dyar, H. G., and Morton, E. L. New York Ent. Soc. Journ. 4:1. 1896.

strigata Müll., Hemithea.

Synonym - Nemoria aestivaria Hüb.

Hosts - Quercus, Crataegus, Corylus, Syringa, Malus, Prunus, and other species.

Injury - Larva eats foliage.

Distribution - Europe, Asia, Japan.

References - Kaltenbach, J. H. Pflanzenfeinde, p. 163.1872.

Spuler, A. Schmetterlinge Europas, 2:5. 1910.

strigosa Fabr., Acronycta

Fam. Noctuidae

Hosts - Prunus, Crataegus, Rhamnus.

Injury - Larva eats foliage.

Distribution - Europe, Asia.

Reference-Spuler, A. Schmetterlinge Europas, 1:137. 1908. 


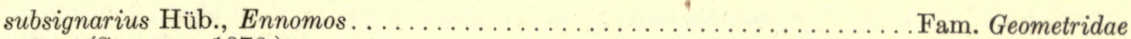
(See page 1076.)

suffusana Z., Notocelia... Fam. Tortricidae

Hosts - Crataegus, Prunus, Pyrus, Malus.

Injury - Larva ties together leaf cluster and feeds within, also eats leaf buds.

Distribution - Europe, Asia Minor.

References - Kaltenbach, J. H. Pflanzenfeinde, p. 209. 1872.

Spuler, A. Schmetterlinge Europas, 2:279. 1910.

superans Guen., Acronycta. Fam. Noctuidae

(See page 1074.)

tesselaris A. and S., Halisidota. Fam. Arctiidae (See page 1073.)

textor Harris, Hyphantria (Fall webworm) (See page 1073.)

Fam. Arctiidae

thysbe Fabr., Hemaris.

Hosts - Viburnum, Symphoricarpus, Crataegus.

Injury - Larva eats foliage.

Distribution - Eastern North America.

References - Fernald, C. H. Sphingidae of New England, p. 16. 1886.

Beutenmueller, William. Hawk moths of the vicinity of New York City, p. 9.1903.

tiliaria Harris, Erranis (Lime-tree spanworm) .................... Fam. Geometridae (See page 1076.)

tineana Hüb., Ancylis. . .

Hosts - Populus, Crataegus, Prunus, Malus.

Fam. Tortricidae

Injury - Larva eats foliage after tying it with silk.

Distribution - Europe.

References - Kaltenbach, J. H. Pflanzenfeinde, p. 209. 1872.

Spuler, A. Schmetterlinge Europas, 2:270. 1910.

tirhaca Cr., Pșeudophia. .

Fam. Noctuidae

Synonym - Ophiusa tirrhaea Cr.

Hosts - Rhus, Pistacia, Crataegus.

Injury - Larva eats foliage.

Distribution - Southern Europe, Asia, Africa, Australia, and islands of southern Pacific.

References - Kaltenbach, J. H. Pflanzenfeinde, p. 208. 1872.

Spuler, A. Schmetterlinge Europas, 1:312. 1908.

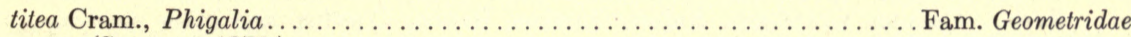

(See page 1076.)

trapezina Linn., Calymnia...

Fam. Noctuidae

Hosts - Quercus, Salix, Crataegus, and other species.

Injury - Larva eats foliage.

Distribution - Europe, Asia.

References - Kaltenbach, J. H. Pflanzenfeinde, p. 208. 1872.

Spuler, A. Schmetterlinge Europas, $1: 244$. 1908.

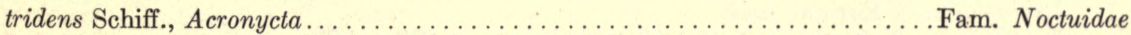
Hosts - Crataegus, Prunus, Malus, Rosa, Salix, Rhamnus, and other species.

Injury - Larva feeds on foliage.

Distribution - Europe, Asia.

References - Kaltenbach, J. H. Pflanzenfeinde, p. 208. 1872.

Spuler, A. Schmetterlinge Europas, 1:137. 1908. 
turnus Linn., Papilio (Tiger swallowtail) ...................... Pamilionidae

Hosts - Crataegus, Malus, Cydonia, Prunus, Betula, Tilia, Quercus, Salix, and other species.

Injury - Larva eats foliage.

Distribution - Eastern North America.

References - Saunders, William. Can. ent. 6:2. 1874.

Packard, A. S. Fifth rept. U. S. Ent. Comm., p. 536. 1890.

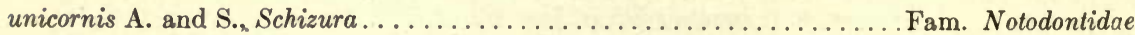

Hosts - Malus, Prunus, Crataegus, Ulmus, Populus, Corylus, Quercus, and other species.

Injury - Larva eats foliage.

Distribution - North America.

Reference-Packard, A. S. Nat. Acad. Sci. Memoir 1:203. 1895.

variegana Hüb., Olethreutes.................................... Tortricidae

Hosts - Malus, Pyrus, Crataegus, Prunus, and other species.

Injury - Larva ties leaf clusters together and eats leaves and buds.

Distribution - Europe, Asia.

References - Newstead, R. Gard. chron. 1901:342. 1901.

Theobald, F. V. Insect pests of fruits, p. 82. 1909.

vernata Peck, Paleacrita (Spring cankerworm).

Frm. Geometridae

Hosts - Ulmus, Malus, Crataegus, and other species.

Injury - Larva eats foliage.

Distribution - North America.

Reference - Wellhouss, W. H. Univ. Kans., Ent. Dept. Bul. 11:283. 1917.

vetusta Boisd., Hemerocampa (Western tussock moth) . . . . . . . . . . . Fam. Lymantriidae

Hosts - Malus, Prunus, Crataegus, Juglans, Quercus, and other species.

Injury - Larva eats leaves and sometimes young fruit.

Distribution - Pacific coast of the United States.

References - Branigan, E. J. State Comm. Hort. California. Mo. bul. 3:245. 1914. Essig, E. O. Injurious and beneficial insects of California, p. 408. 1915.

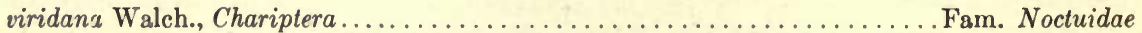

Hosts - Prunus, Crataegus, Pyrus.

Injury - Larva eats foliage at night.

Distribution - Europe.

Reference - Spuler, A. Schmetterlinge Europas, 1:204. 1908.

viridata Linn., Nemorix............................ Fam. Geometridae

Hosts - Calluna, Cratzegus, Rubus, Quercus, Betula, Corylus, and other species.

Injury - Larva eats foliage.

Distribution - Europe, Asia.

References - Kaltenbach, J. H. Pflanzenfeinde, p. 235. 1872.

Spuler, A. Schmetterlinge Europas, 2:4. 1910.

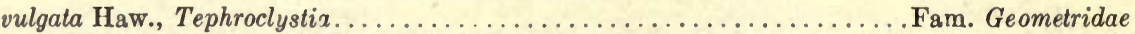

Hosts - Cratregus, Polygonum, Rubus, and other species.

Injury - Larva eats foliage.

Distribution - Europe, Asia.

References - Kaltenbach, J. H. Pflanzenfeinde, p. 209. 1872.

Spuler, A. Schmetterlinge Europas, 2:75. 1910.

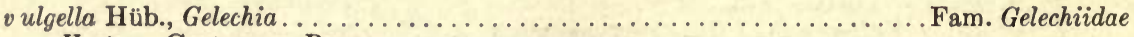

Hosts - Crataegus, Prunus. 
Injury - Larva ties together a cluster of leaves and feeds within.

Distribution - Europe.

References - Keltenbach, J. H. Pflanzenfeinde, p. 210. 1872.

Spuler, A. Schmetterlinge Europas, 2:358. 1910.

\section{DIPTERA}

absobrina Felt, Rhizomyia .

Hosts - Crataegus, Populus, Prunus virginiana.

Injury - Larva found in leaf gall.

Distribution - North America.

Reference - Felt, E. P. New York State Mus. Bul. 200:138. 1918.

anthobia F. Loew, Contarina............................ Fam. Cecidomyiidae

Host - Crataegus oxyacantha.

Injury - Solitary larva feeds in blossom bud, causing it to remain closed and swollen.

Distribution - Europe.

References - Ross, H. Die Pflanzengallen Mittel- und Nordeuropas, p. 132. 1911. Bagnall, R. S., and Harrison, J. W. H. Ent. Soc. London. Trans. 1917:391. 1917.

bedeguar Walsh, Cecidomyia (Tufted thorn gall) ..................... Cecidomyiidae

Host - Crataegus.

Injury - Larvae deform leaves with filamentous subglobular vein galls, $1 \mathrm{~cm}$. long, generally found on the midveins.

Distribution - North America.

References - Walsh, B. D. Can. ent. 1:79. 1869.

Felt, E. P. New York State Mus. Bul. 200:138. 1918.

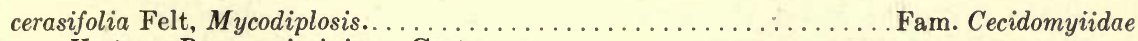

Hosts - Prunus virginiana, Crataegus.

Injury - Larvae live in galls on hawthorn fruit caused by Gymnosporangium clavipes, and feed on the rust spores.

Distribution - North America.

References - Felt, E. P. New York State Mus. Bul. 200:152. 1918.

Wellhouse, W. H. Ent. news 30:144. 1919.

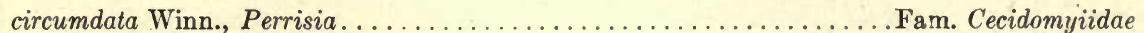

Host - Crataegus oxyacantha.

Injury - Larva lives in leaf gall.

Distribution - Germany.

References - Kaltenbach, J. H. Pflanzenfeinde, p. 212. 1872.

Kieffer, J. J. Genera insectorum, fasc. 152, p. 75. 1913.

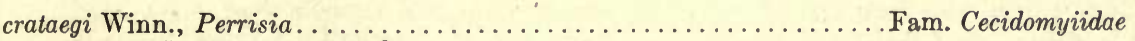

Host - Crataegus oxyacantha.

Injury - Colonies of larvae cause rosettes of deformed sessile leaves, which make trees and hedges unsightly.

Distribution - Europe.

References - Kaltenbach, J. H. Pflanzenfeinde, p. 212. 1872.

Connold, E. T. British vegetable galls, p. 190.1902.

crataegifolia Felt, Hormomyia (Thorn cockscomb gall).............Fam. Cecidomyiidae

Host - Crataegus.

Injury - Larva deforms leaf with a green or red gall $1 \mathrm{~cm}$. long, shaped like a cockscomb.

Distribution - United States.

References - Felt, E. P. Journ. econ. ent. 1:20. 1908.

Felt, E. P. New York State Mus. Bul. 200:136. 1918.

(Figs. 116 and 117, page 1032.) 
crataegifolia Felt, Lestodiplosis (Hawthorn fringed-cup gall)...........Fam. Cecidomyiidae Host - Crataegus.

Injury - Larva causes a gall on leaf or twig.

Distribution - United States.

References - Felt, E. P. New York State Mus. Bul. 124:408. 1908. Felt, E. P. New York State Mus. Bul. 200:138. 1918.

(Figs. 114 and 115, page 1081.)

excavata Felt, Lasioptera (Purple leaf blotch)...................Fam. Cecidomyiidae Host - Crataegus.

Injury - Larvae deform leaves with green or reddish, blister-like mines, about $8 \mathrm{~mm}$. in diameter.

Listribution - United States.

Reference - Felt, E. P. New York State Mus. Bul. 200:138. 1918.

hirta Felt, Rhizomyia..............................Fam. Cecidomyiidae Host - Crataegus.

Injury - Species probably inquiline in blister mine made by Lasioptera excavata.

Distribution - United States.

Reference - Felt, E. P. New York State Mus. Bul. 200:138. 1918.

hudsonici Felt, Winnertzix..............................Fam. Cecidomyiidae

Host - Crataegus.

Injury - Larva deforms leaf with stout, cup-shaped, fimbriate, unicellular gall.

Distribution - United States.

Reference - Felt, E. P. New York State Mus. Bul. 200:138. 1918.

pomonella Walsh, Rhagoletis (Apple maggot).................... Fam. Trypetidae

Hosts - Crataegus, Malus, Vaccinium, Symphoricarpos.

Injury - Larva tunnels in fruit.

Distribution - Eastern North America.

References - Walsh, B. D. First annual report on noxious insects of Illinois, p. 30. 1868.

O'Kane, W. C. New Hampshire Agr. Exp. Sta. Bul. 171. 1914.

Severin, H. H. P. State Comm. Hort. California. Mo. bul. 7:430. 1918.

venxe Felt, Lobopteromyix (Thorn vein gall) . ..................Fam. Cecidomyiidae

Host - Crataegus.

Injury - Larva causes oval, smooth, fleshy gall, 5 to $8 \mathrm{~mm}$. long, on leaf vein.

Distribution - United States.

-Reference - Felt, E. P. New York State Mus. Bul. $200: 138.1918$.

(Figs. 118 and 119, page 1083.)

venitalis Felt, Dicrodiplosis.

Fam. Cecidomyiidae

Host - Crataegus.

Injury - Larva found in same gall with Lobopteromyia venae.

Distribution - United States.

Reference - Felt, E. P. New York State Mus. Bul. 200:138. 1918.

Cecidomyia sp. (a. 2727 Felt) .............................Fam. Cecidomyiidae Host - Crataegus.

Injury - Larvae cause subglobose, greenish, sometimes confluent, frequently pointed, polythalamous vein galls, the under side reddish, diameter $3 \mathrm{~mm}$. Distribution - United States.

Reference - Felt, E. P. New York State Mus. Bul. 200 : 138. 1918.

Cecidomyia sp. (a. 1840 Felt) (Thorn spindle gall)..................n. Cecidomyiidae Host - Crataegus. 
Injury - Larva causes a spindle-shaped thickened gall on leaf vein, green or reddish, length $1 \mathrm{~cm}$., diameter $2 \mathrm{~mm}$.

Distribution - Eastern United States.

Reference-Felt, E. P. New York State Mus. Bul. 200:138. 1918. (Figs. 120 and 121, page 1094.)

\section{HYMENOPTERA}

betuleti Klg., Trichiosoma.............................Fam. Tenthredinidae

Synonyms - Cimbex crataegi Wd., Trichiosoma tibialis Steph.

Host - Crataegus.

Injury - Larva eats foliage.

Distribution - Europe.

efer nces - Kaltenbach, J. H. Pflanzenfeinde, p. 211. 1872.

André, Ed. Species des Hyménoptères d'Europe, 1:27. 1879.

cerasi Linn., Caliroa (Pear and cherry slug) . .................Fam. Tenthredinidae

Hosts - Prunus, Crataegus, Pyrus, and other species.

Injury - Larvae skeletonize leaves.

Distribution - Europe, North America, Australia.

References - Slingerland, M. V., and Crosby, C. R. Manual of fruit insects, p. 214. 1914.

MacGillivray, A. D. Hymenoptera of Connecticut, p. 79. 1916.

collaris MacG., Profenusa (Cherry and hawthorn sawfly leaf miner).... Fam. Tenthredinidae Hosts - Crataegus, Prunus cerasus.

Injury - Larva mines in leaf, causing brown blister which may cover from a quarter to the whole of the upper surface of the leaf.

Distribution - Massachusetts, New York.

Reference - Parrott, P. J., and Fulton, B. B. New York (Geneva) Agr. Exp. Sta. Bul. 411. 1915.

druparum Boh., Syntomaspis (Apple seed chalcid) ................ Fam. Chalcididae

Hosts - Malus, Pyrus, Sorbus, Crataegus.

Injury - Oviposition punctures cause dimples in fruit, and larvae destroy seeds.

Distribution - Europe, North America.

References - Schlechtendall, D. von. Ztschr. Naturwiss. Halle 61:415. 1888.

Cushman, R. A. Journ. agr. res. 7:487. 1916.

Woodruffe-Peacock, E. A. Naturalist (London), no. 753, p. 329. 1919.

flaviventris Retz., Lyda.

Fam. Tenthredinidae

Synonym - Lyda clypeata Klg.

Hosts - Crataegus, Pyrus.

Injury - Larvae defoliate branches, feeding in colonies.

Distribution - Europe.

References - Kaltenbach, J. H. Pflanzenfeinde, p. 206. 1872.

André, Ed. Species des Hyménoptères d'Europe, 1:516. 1879.

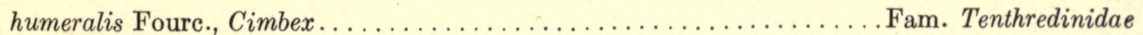

Synonym - C'imbex axillaris Pz.

Hosts - Crataegus, Prunus padus.

Injury - Larva feeds on foliage.

Distribution - Europe.

References - Kaltenbach, J. H. Pflanzenfeinde, p. '212. 1872.

André, Ed. Species des Hyménoptères d'Europe, 1:24. 1879. 
padi Linn., Priophorus. .............................. Tenthredinidae

Hosts - Crataegus, Pyrus, Prunus, Malus, Sorbus, and other species.

Injury - Larva skeletonizes leaves.

Distribution - Europe.

References - André, Ed. Species des Hyménoptères d'Europe, 1:84. 1879.

Collinge, W. E. Manual of injurious insects, p. 219. 1912.

punctum-album Linn., Macrophya .......................... Tenthredinidae

Hosts - Fraxinus, Ligustrum, Crataegus.

Injury - Larva feeds on foliage.

Distribution - Europe.

Reference-André, Ed. Species des Hyménoptères d'Europe, 1:359. 1879.

Four species of unidentified sawflies (pages 1086 and 1087.) 


\section{INDEX OF GENERA AND SPECIES}

(Synonyms are in italics)

A

Acalla contaminana............... 1113 holmiang.

Acrobasis nebulella.

Acronycta americana.

dactylina...

euphorbiae...

luteicoma.

occidentalis...

psi.

radcliffei...

strigosa.

superans...... tridens.

Aegeria pyri.

Agrilus politus

$$
\text { sinuatus. }
$$

vittaticollis.

Agriotes pubescens.

Alsophila pometeria.

Alticopus galeazii.

Amphidasis betularia.

Amphipyra pyramidea.

pyramidoides.

Ancylis nubeculana.. selenana. tineana.

Anisopteryx aescularia.

Anthaxia quercata.

Anthonomopsis mixtus.

Anthonomus decipiens.

decipiens. $\ldots \ldots \ldots \ldots \ldots \ldots \ldots \ldots \ldots \ldots$
flavicornis. $\ldots \ldots \ldots \ldots \ldots \ldots$
nebulosus. $\ldots \ldots \ldots \ldots \ldots \ldots$

pomorum.................. 1106

Aphis avenae (Amer, authors)........... 1098

avenae Fabr. . . . . . . . . . . . . . . 1097

bakeri..................... 1092

brevis. 1092

crataegi Buck. . . . . . . . . . . . . . 1094

crataegi Kalt. . . . . . . . . . . . . . . . 1093

crataegi Koch. . . . . . . . . . . . . . . . . . 1093

crataegiella........................ 1094

crataegifoliae..............., 1064, 1094

crataegus-coccinea................ 1094

edentula.................... 1095

fitchii. . . . . . . . . . . . . . . . 1098

mali . . . . . . . . . . . . . . . . . . . . 1098

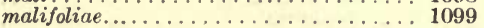

marutae. . 1096

oxyacanthae Koch. . . . . . . . . . . . 1097

oxyacanthae Schr................... 1098

padi. . . . . . . . . . . . . 1097

pomi................... 1065, 1098

pyri...................... 1093

ranunculi................... 1093

rumicis...................... 1099

sorbi......................... 1099

Apion pomonae ................. 1106

Aporia crataegi . . . . . . . . . . . . . 1113

Archips argyrospila.............. 1077, 1110

Argyresthia ephippella............... 1115

nitidella............... 1120

oreasella.............. 1078, 1121
Argyroploce pruniana.................. 1115

1123

1095

1095

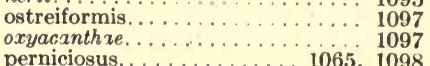

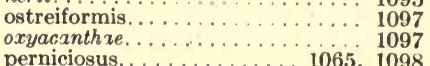

perniciosus............. 1065, 1098

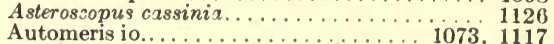

B

Basilarchia arthemis............... 1110 astyanax.................... 1110

Blastodacna curvilineella... . . . . . . . 1080, 1114 hellerella................ 1116

Brachionycha sphinx..................... 1126

Brachys aerosus................. 1066, 1101

Bucculatrix crataegi . . . . . . . . . . . . 1113 pomifoliella.............. 1079, 1122

Byturus tomentosus . . . . . . . . . . . . 1108

\section{C}

Cacoecia crataezana . . . . . . . . . . . . . 1113

rosaceana............ 1078, 1125

rosana................. 1125

Caliroa cerasi................... 1086, 1131

Calligrapha multipunctata............ 1105

Calymnia trapezina................ 1127

Capsus medius ............................ 1097

Capua angustiorana . . . . . . . . . . . . 1109

Catocala blandula . . . . . . . . . . . . . 1111

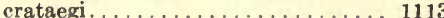

fulminea................

paranympha.................. 1115

polygama.................. 1122

Cecidomyia bedeguar . . . . . . . . . . . 1129

sp. (a. 1840 Felt)... . . . 1082, 1130

sp. (a. 2727 Felt) . . . . . . . 1130

Cemiostoma scitella................ 1125

Ceratocapsus pumilus. . . . . . . . . . . . . . 1099

Ceresa bubalis. .................... 1092 taurina................. 1063, 1100

Ceroplastes rusci . . . . . . . . . . . . . . . . . . . . 1099

Chalepus dorsalis. . . . . . . . . . . . . . . . 1103

Chariptera viridana................ 1128

Cheimatobia brumata................. 1111

Chermes quercus. ...................., 1094

Chionaspis furfura.............. 1065, 1095

Choragus scheppardi................... 1107

Chrysobothris femorata............. 1050, 1103

Cilex glaucatus.................... 1116

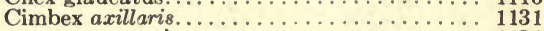
crataegi.................. 1131

humeralis.......................

Cnephasia nubilana. . . . . . . . . . . . 1120

Coleophora anatipennella. . . . . . . . . . . 1109

fletcherella............ 1079, 1115

hemerobiella.............. 1116

malivorella.............. 1079, 1119

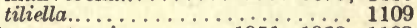

Conotrachelus erataegi. . . . . . . 1051, 1068, 1103 
Conotrachelus naso............... 1105

nenuphar............. 1105

posticatus. . . . . . . 1106

Contarina anthobia................. 1129

Coptodisca splendoriferella.......... 1079, 1126

Corythucha arcuata. . . . . ............ 1095 bellula................. 1056, 1092

brunnea...................... 1092

crataegi..................... 1095

cydoniae............... 1095

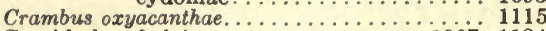

Crepidodera helxines.............. 1067, 1104

Cryptocephalus bipunctatus. . . . . . . . . 1050, 1101

Cydia pomonella .................... 1122

D

Dasychira pudibunda.

$11: 3$

Datana integerrima.. ministra.

1075,1119

Deraeocoris olivaceus

Diaphnidia pellucida.

1097

Diaspis piri.

1055,1098

Dibolia borealis.

Dichelia grotiana.

Dichelony chs olongata.

testacea.

1067.110

1102

1066,1103

1067,1108

Dicrodiplosis venitalis.............. 1130

Diloba coeruleocephala.................. 1112

Diphucephala colaspidoides............ 1102

\section{E}

Eccoptogaster pruni................ 1106

Empos querci rugulosus............ 1107

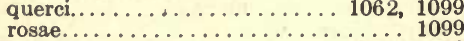

Empoasca mali................... 1061, 1096

Ennomos magnarius. . . . . . . . . . . . . 1076, 1119

subsignarius.............. 1076, 1127

Epetrimerus armatus. . . . . . . . . . . 1090

Epiblema biscutana................... 1111

Epicnaptera americana............ 1075, 1109

Epidiaspis betulae. . . . . . . . . . . . . . 1092 leperi................... 1092 piricola ................ 1092

Epigraphia steinkelneriana.............. 1126

Epitrix cucumeris................ 1067, 1103

Erineum clandestinum................ 1090

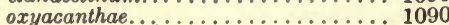

Eriogaster catax.................. 1111 lanestris.................. 1117

Eriophyes calycobius.................... 1090 crataegi.................. 1090 crataegi-vermiculus.............. 1090 goniothorax.............. 1053, 1090 pyracanthae............... 1090

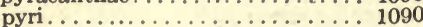
sp. No. 1................. 1052, 1091 sp. No. $2 \ldots \ldots \ldots \ldots \ldots \ldots \ldots \ldots \ldots \ldots \ldots \ldots \ldots \ldots$ sp. No. $3 \ldots \ldots \ldots \ldots \ldots \ldots \ldots \ldots 1053$

Eriosoma crataegi. lanigera.......... 1051, 1064, 1096

Erranis tiliaria.................. 1076, 1127

Erythroneura obliqua.............. 1061, 1097

Eulecanium pyri. . . . . . . . . . . . 1093

Eulia quadrifasciana............... 1078, 1124

Euproctis chrysorrhea................. 1112

Eupteryx vanduzei. . . . . . . . . . . 1062, 1100

Euscelis curtisii. . . . . . . . . . . . . . . 1061, 1094

Eutettix seminudus... . . . . . . . . . . 1062, 1099

Euthrips tritici................ 1066, 1100

Exapate congelatelia.................. 1112
Gastropacha quercifolia............... 1124

Gelechia spurcella . . . . . . . . . . . . . . 1126 vulgella . . . . . . . . . .

Glossonotus crataegi............... 1063, 1093

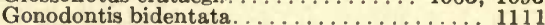

Graphocephala coccinea............. 1061, 1093

Grapholitha janthinana............... 1117 kroesmanniana................... 1125

\section{H}

Halisidota caryae.............. 1073, 1111

tesselaris............. 1073, 1127

Haltica carinata.................. 1067, 1102 foliaces..................... 1104

Hemaris thysbe .................. 1127

Hemerocampa leucostigma......... 1075, 1118

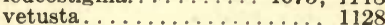

Hemithea strigata. . . . . . . . . . . 1126

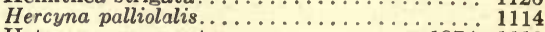

Heterocampa manteo................ 1074, 1119

Heterocordylus malinus. ....... 1051, 1054, 1096

Hibernia aurantiaria................ 1110

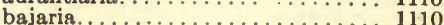
defoliaria................. 1114 leucophaearia............... 1118 marginaria................ 1119

Holcophora fasciellus. . . . . . . . . . 1115

Horcias dislocatus.............. 1054, 1095

Hormomyia crataegifolia. . . . . . . . 1082, 1129

Hyphantria textor............... 1073, 1127

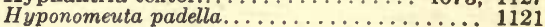

\section{I}

Idiocerus crataegi. . . . . . . . . . . . . . . 1094 fitchi..................... 1095 lachrymalis............ 1061, 1095 maculipennis. ............... 1095 pallidus................ 1062, 1098 provancheri.............. 1062, 1098 suturalis................. 1062, 1100

Idiostethus tubulatus. . . . . . . . . . . . . 1108

L

Lamenia vulgaris.............. 1063, 1100 Lasiocampa quercus. . . . . . . . . . . . . . . . . . 1124

Lasioptera excavata . . . . . . . . . . . . . . 1130

Laspeyresia prunivora. . . . . . . 1051, 1078, 1123

Lecanium bituberculatum . . . . . . . . . . . . . . 1092

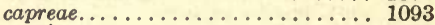
corni.................. 1065, 1093

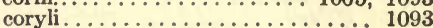
nigrofasciatum . . . . . . . . . 1097 pruinosum.................. 1098

Lepidosaphes ulmi.................. 1065, 1100

Lestes viridis. . . . . . . . . . . . . . . . 1048, 1091

Lestodiplosis crataegifolia. . . . . . . . . 1080, 1130

Limnobaris calva....................... 1102

Limonius dubitans. . . . . . . . . . . . . . 1066, 1103

Liparis auriflua .................... 1125

Lithocolletis betulae $\ldots \cdots \cdots \cdots \cdots \cdots \cdots$

cerisolella.............. 1112

concomitella.............. 1112

corylifoliella ................. 1113

crataegella.............. 1113

malimalifoliella.............. 1119

oxyacanthae................. 1121

pomifoliella................ 1112

prunivorella..................... 1116

Lobopteromyia venae............... 1082, 1130

Lophopteryx cuculla. . . . . . . . . . . . . 1114

Lycia cognataria................ 1076, 1112 
PAGE

Lyda clypeata................... 1131 flaviventris . . . . . . . . . . . . . 1131

Lygidea mendax. . . . . . . . . . . 1051, 1055, 1096

Lygus communis. . . . . . . . . . . . . . 1054, 1093 ostryae................ 1055, 1097 pratensis................ 1055, 1098 univittatus. . . . . . . . . . 1055, 1100

Lymantria dispar.......................... 1114

Lyonetia clerkella................. 1112

\section{M}

Macrodactylus subspinosus. . . . . . . . . 1108

Macrophya punctum-album. . . . . . . . . . 1132

Macrosiphum erataegarium............. 1093 crataegi............ 1063, 1094

Magdalis aenescens................... 1101

barbicornis............... 1101

cerasi................... 1102

nitidipennis................... 1105

pruni................... 1106

Malacosoma americana............ 1075, 1109

disstria.............. 1114

- neustria....................... 1120

Melanoplus atlanis............... 1054, 1091 bivittatus............... 1054, 1091 femur-rubrum........... 1054, 1091

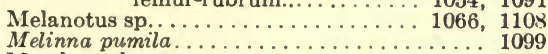

Mesoleuca lacustrata . . . . . . . . . . . . 1117

Mineola indigenella............. 1077, 1117

Miselia oxyacanthae............... 1121

Mycodiplosis cerasifolia . . . . . . . . . . 1129

Mytilaspis pomorum................. 1100

Myzus oxyacanthae............... 1097

\section{$\mathrm{N}$}

Nacophora quernaria . . . . . . . . . . . . . 1124

Nematocampa filamentaria ............... 1118

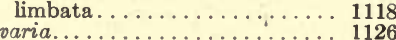

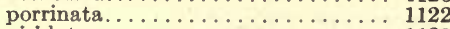

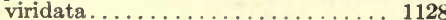

Nepticula aterrima. . . . . . . . . . . 1110

atricollis. .................... 1110

crataegifoliella .............. 1114

gratiosella............... 1116

ignobilella............... 1117

nitidella. 1120

oxyacanthella............. 1121

prunetorum.............. 1123

pygmaeella. ................ 1123

regiella................. 1124

scintillans . . . . . . . . . . . 1125

Nola cucullatella.................. 1114

Notocelia suffusana. . . . . . . . . . . 1127

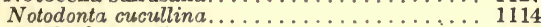

Notolophus antiqua................ 1110

O

Oecanthus niveus................. 1048, 1091

Olethreutes achatana.................. 1109 chionosema.......... 1077, 1112 variegana .................. 1128

Ophiderma flavicephala............. 1063, 1095

Ophiusa tirrhaea.................... 1127

Opisthograptis luteolata. . . . . . . . . . . . . . 1119

Orchestes rufus $\ldots \ldots \ldots \ldots \ldots \ldots \ldots \ldots \ldots 1107$

Ornix anglicella ..................... 1109

crataezifoliella. ................ 1114

geminatella................ 1116

Orthotylus atumella................. 1117

Otiorrhynchus caudatus.

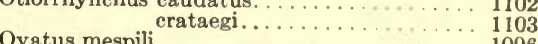

1096

\section{$\mathbf{P}$}

Paleacrita vernata.

1076,1128

Pamene rhediella.

1124

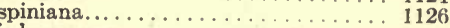

Pandemis heparana.................... 1116

ribeana................. 1125

Paonias myops................... 1119

Papilio podalirius...................... 1122

turnus............... 1072, 1128

Parlatoria oleae. . . . . . . . . . . . . . . . 1097

Pemphigus corrugatans. . . . . . . . . 10 3, 1093

Penthina robrana........................ 1113

Perrisia circumdata. . . . . . . . . . . . . 1129

crataegi.................. 1129

Phenacoceus aceris. . . . . . . . . . . . . 1091

betheli. . . . . . . . . . . 1095

dearnessi............... 1095

Phigalia pedaria.....................

Philaenus lineatus. . . . . . . . . . . 1061, 1096

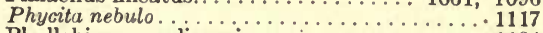

Phyllobius maculicornis. . . . . . . . . . . . . . . 1104 oblongus.... ............. 1105

Physatocheila dumetorum.............. 1095

Pineapple gall (maker unknown) . . . . . . . . . 1085

Platysamia cecropia.................. 1111

Poecilocampa populi. .................. 1122

Polydrusus impressifrons . . . . . . . . . . . . . . 1104 pterygomalis............ 1107 sericeus...................... 1107

Porthesia similis. . . . . . . . . . . . . . . . 1125

Priophorus padi................... 1132

Prociphilus crataegi................. 1094

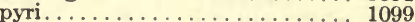

Prodenia praefica.................. 1122

Profenusa collaris..................... 1131

Psallus ambiguus. . . . . . . . . . . . . . . . . 1091

Pseudanthonomus crataegi . . . . . . . . . . 1103

Pseudophia tirhaca................ 1127

Psylla costalis...................... 1093

crataegi Schr................ 1094

crataegi Först. . . . . . . . . . . 1096

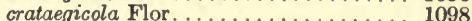

crataegicola Först. . . . . . . . . . . . 1096

mali.................... 1049, 1096

melanoneura................. 1096

peregrina. . . . . . . . . . . . . . . . 1098
saliceti. . . . . . . . . . . . . 1099

Pulvinaria betulae................... 1100

innumerabilis............ 1100

oxyacanthxe.................. 1100

vitis.............. 1065, 1100

Pyrausta purpuralis............... 1123

$\mathbf{R}$

Ramphus flavicornis. . . . . . . . . . . . . . 1104

oxyacanthae..................... 1104

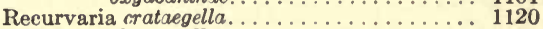

leucatella................ 1118

nanella................ 1051, 1120

Rhagoletis pomonella...........1050, 1085, 1130

Rhizomyia absobrina.. . . . . . . . . . 1080, 1129

hirta..................... 1130

Rhodophaea advenella ................. 1109

Rhopalosiphum padi................ 1097 
Rhopalosiphum prunifoliae......... 1065, 1098

Rhopobota naevana. . . . . . . . . . . . . 1120

Rhynchites aeneovirens var. punctatus. . . . . 1100 aequatus................. 1101 auratus .................. 1101

bacchus Linn. . . . . . . . . . . . 110

bacchus Oliv................ 110

coeruleocephalus............ 1102

comatus................. 1105

conicus .................. 1104

cyanicolor ................. 1107

giganteus................ 1104

icosandriae.............. 1104

olivaceus. 1105

ophthalmicus.............. 1108

pauxillus................ 1105

pubescens.................. 1107

sericeus. . . . . . . . . . . 1108

Rosalia alpina $: \ldots \ldots \ldots \ldots \ldots \ldots \ldots \ldots . . \ldots 1101$

Rumia crataegata.

$\mathrm{S}$

Saperda bivittata.................. 11C2

candida. . . . . . . . . . . . . 1102

cretata............................. 1103

favi.

Sawfly No. 1................. 1086, 1132

Sawfly No. $2 \ldots \ldots \ldots \ldots \ldots \ldots \ldots \ldots \ldots$ 1086, 1132

Sawfly No. 3 .

Sawfly No. $4 \ldots \ldots \ldots \ldots \ldots \ldots \ldots \ldots$. 1087, 1132

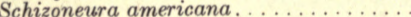

Schizura concinna unicornis................ 1128

Scythropia crataegella . . . . . . . . . . . 1113

Selenia lunaria. . . . . . . . . . . . . . 1118

Sesia pyri..................... 1124 scitula................. 1076, 1125

Sibine stimulea .................. 1126

Simaethis fabriciana . . . . . . . . . . . 1115 pariana.............. 1051, 1121

Sphecodina abbotti................. 1108

Steganoptycha signatana............. 1125

Strymon calanus. .................. 1111

liparops................. 1118

melinus................. 1119

Swammerdamia lutarea.............. 1118

oxyacanthella.......... 1118

Syneta albida. . . . . . . . . . . . . . . 1101
Syntomaspis druparum. . . . . . . . . . . . 1131

Systena marginalis. . . . . . . . . . . . 1067, 1105

$\mathrm{T}$

Tachypterus quadrigibbus . . . . .

Taeniocampa gothica . . . . . . . . . . . . 1116 incerta............... 1117

instabilis . . . 1117

Telea polyphemus. . . . . . . . . . . . . 1122

Tephroclystia vulgata................ 1128

Tetraneura ulmi. ......................... 1100

Tetranychus pilosus. . . . . . . . . . . . . . 1090

telarius. ................ 1051, 1091

Thamnotettix clitellarius............ 1061, 1092

Thecla falacer. . ..................... 1111

Thyridopteryx ephemeraeformis . . . . . . . . 1115

Tinea oxyacanthella $\ldots \ldots \ldots \ldots . \ldots \ldots$

Tischeria malifoliella.................. 1119

Tmetocera ocellana................. 1078, 1120

Tortrix incisana laevigana..................... 1125

Trichiosoma betuleti. . . . . . . . . . . . . . 1131 tibialis................. 1131

Trichiura crataegi. . . . . . . . . . . . . 1114

Trichosea ludifica . . . . . . . . . . . . . . . . . . 1118

Trioza urticae. ..................... 1100

Triphosa dubitata ................... 1115

Trochilium myopiforme . . . . . . . . . . . . . . 1119

Typhlocyba crataegi. . . . . . . . . . . . . . 1094

Tymnes metasternalis. . . . . . . . . . . . . 1105

Valeria oleagina................ 1121

W

Winnertzia hudsonici............... 1130

$\mathrm{X}$

Xanthonia villosula.............. 1067, 1108

Xylotrechus convergeus. . . . . . . . . . . . . 1102

Y

Yponomeuta cognatellus. . . . . . . . . . 1112 padellus............. 1051, 1121

Z

Zeuzera aesculi...................... 1124

pyrina................. 112 




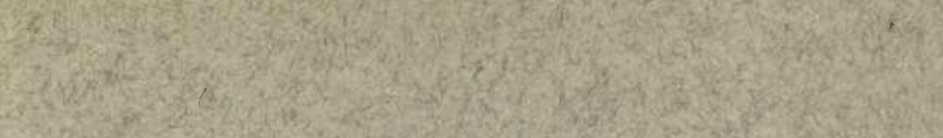

\&is

3.

if:

and

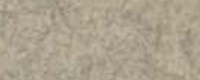

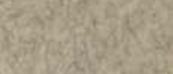

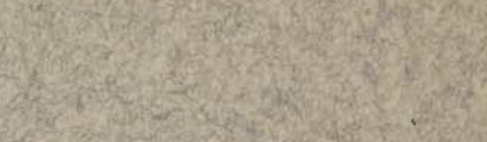

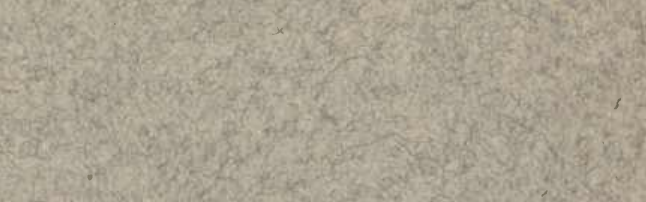

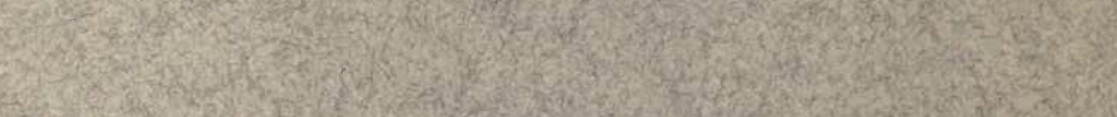

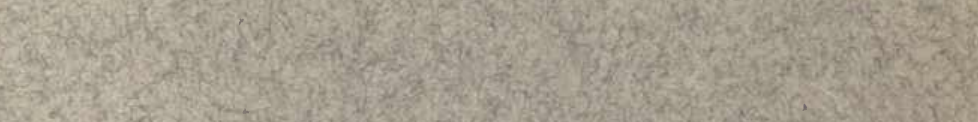

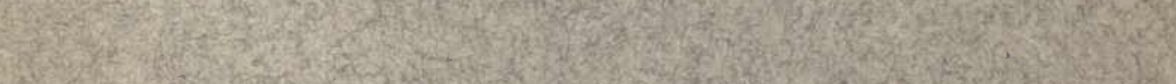

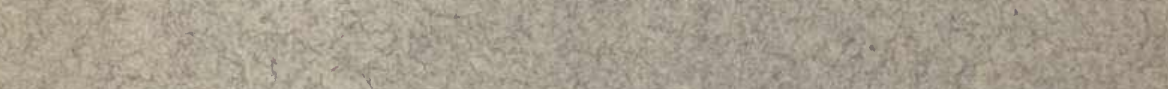

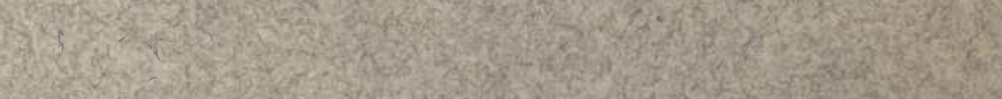

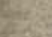

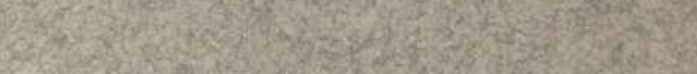




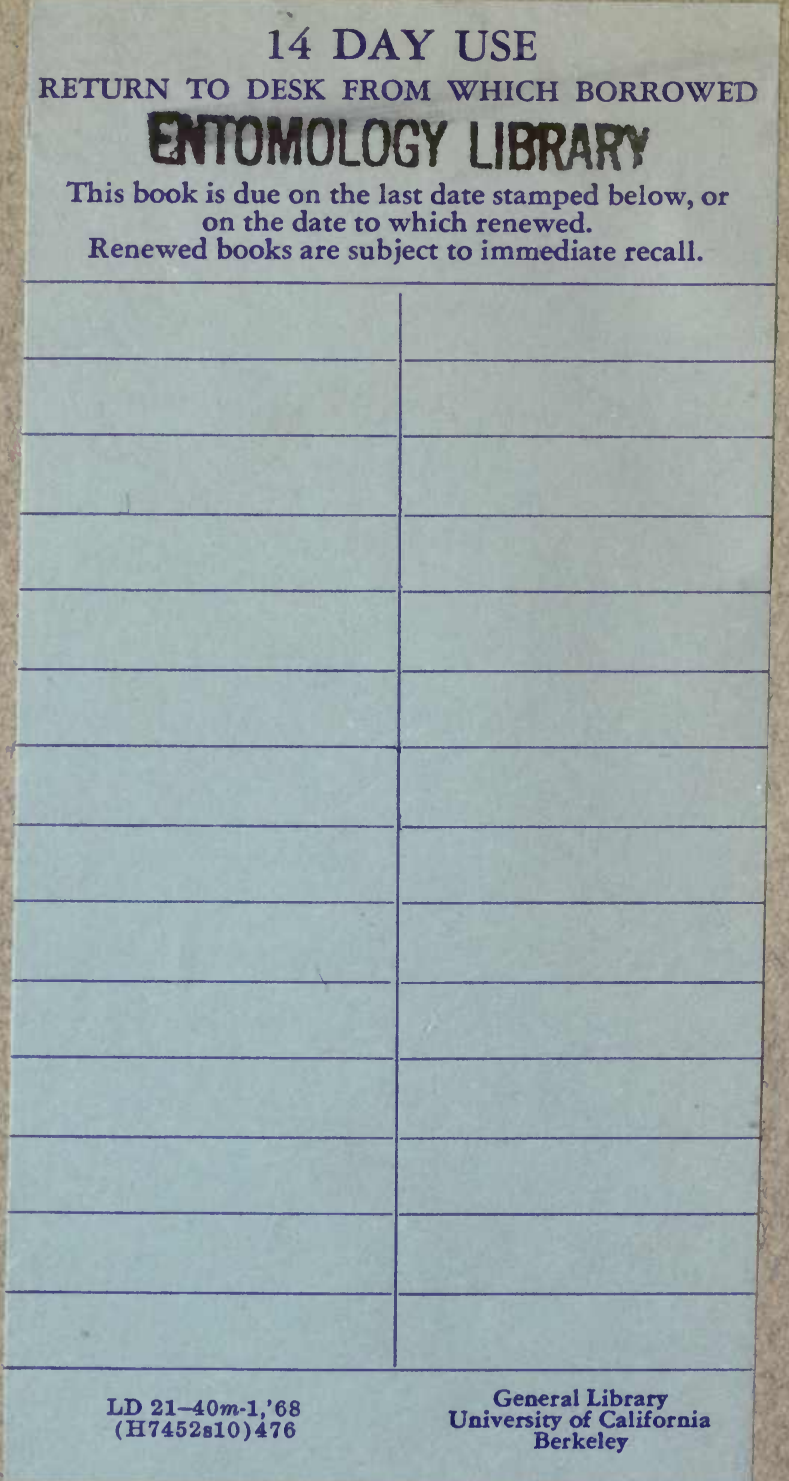


U. B. BERKELEY LIBRARIES

|

C03713876?

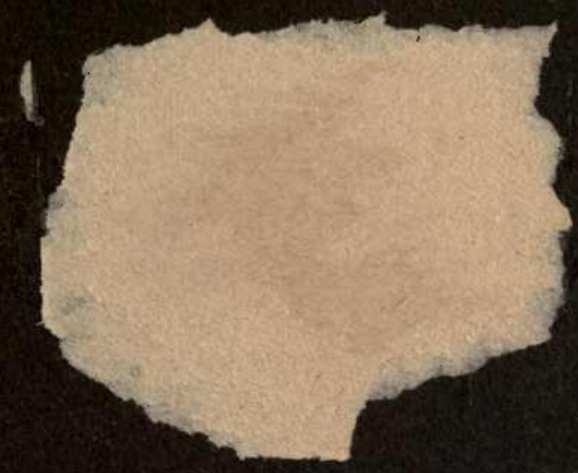


